\title{
yבISWW
}

(OG-W9) K6010

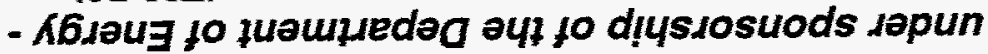

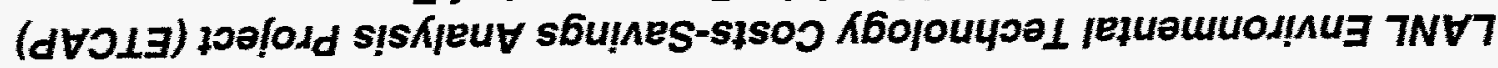

Kq posedasd

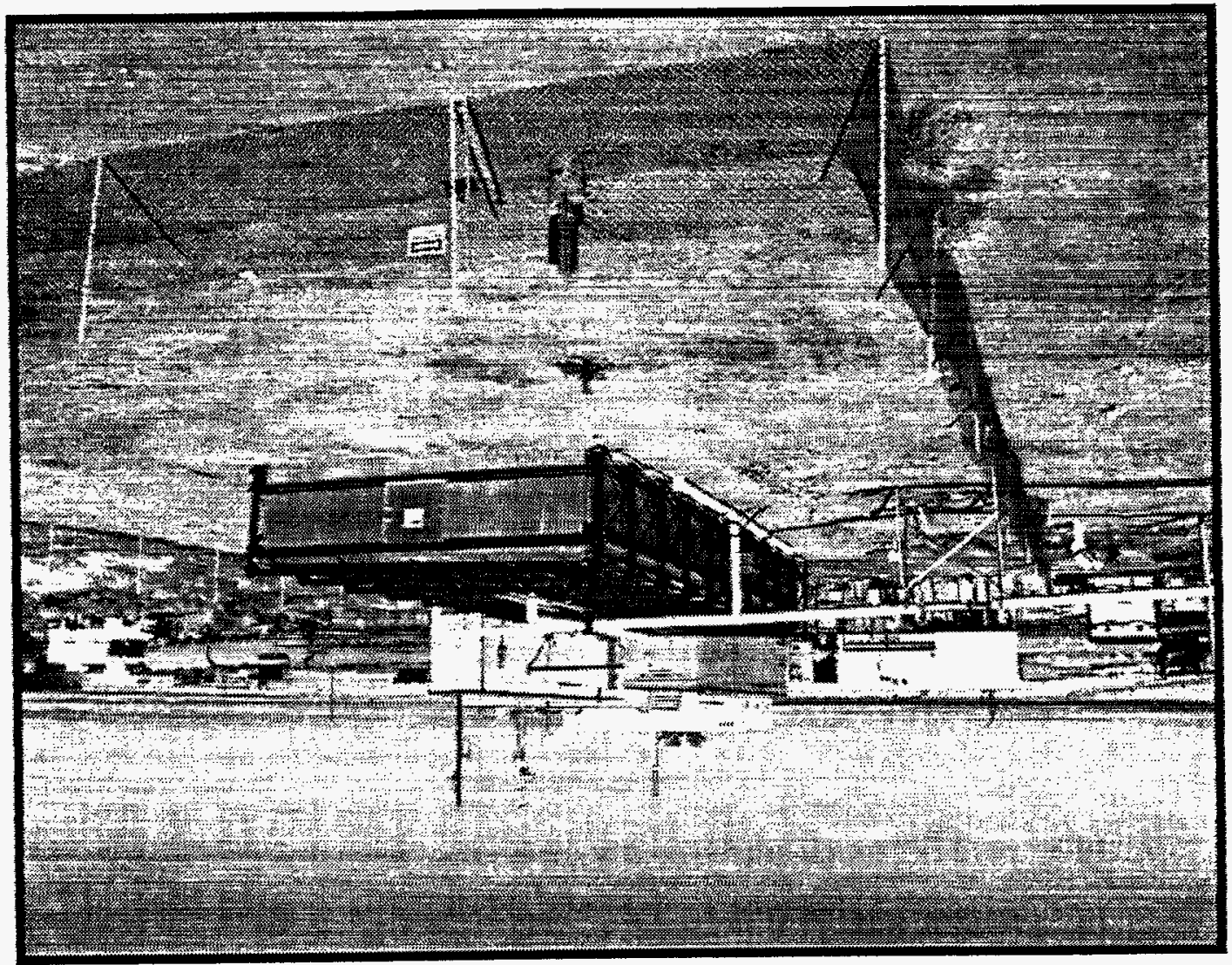

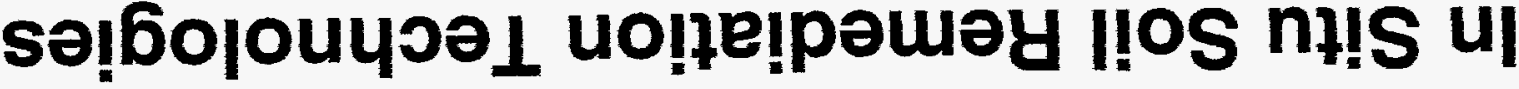

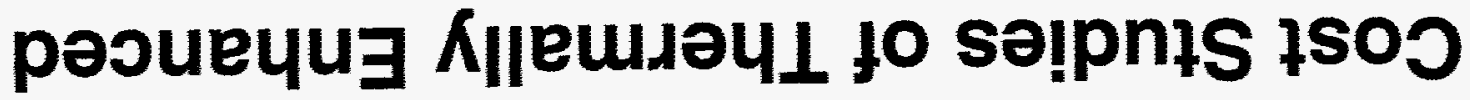

SOUEIV SOT

966। KeW

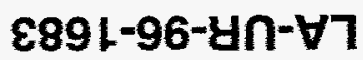

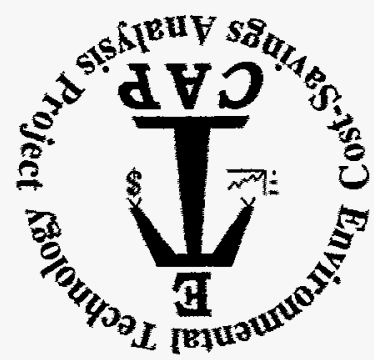



LA-UR-96-1683

May 1996

\section{Cost Studies of Thermally Enhanced In Situ Soil Remediation Technologies}

John Bremser

Steven R. Booth

Energy and Environmental Analysis (TSA-4)

Los Alamos National Laboratory

Los Alamos, NM 87545

By acceptance of this article, the publisher recognizes that the U S Government retains a nonexclusive, royalty-free license to publish or reproduce the published form of this contribution or to allow others to do so for U S Government purposes.

The Los Alamos National Laboratory requests that the publisher identify this article as work performed under the auspices of the U $S$ Department of Energy. 


\section{DISCLAIMER}

Portions of this document may be illegible in electronic image products. Images are produced from the best available original document. 


\section{DISCLAIMER}

This report was prepared as an account of work sponsored by an agency of the United States Government. Neither the United States Government nor any agency thereof, nor any of their employees, makes any warranty, express or implied, or assumes any legal liability or responsibility for the accuracy, completeness, or usefulness of any information, apparatus, product, or process disclosed, or represents that its use would not infringe privately owned rights. Reference herein to any specific commercial product, process, or service by trade name, trademark, manufacturer, or otherwise does not necessarily constitute or imply its endorsement, recommendation, or favoring by the United States Government or any agency thereof. The views and opinions of authors expressed herein do not necessarily state or reflect those of the United States Government or any agency thereof. 


\section{Contents}

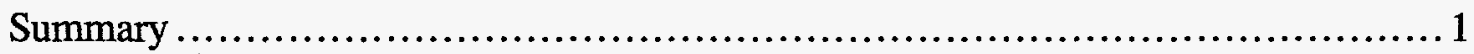

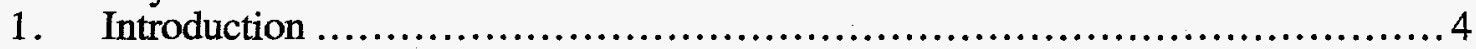

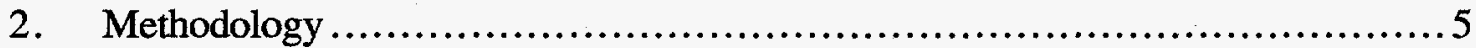

3. Description of Scenarios ......................................................

3.1 Shallow Vadose Contamination.............................................8

3.2 Deep Vadose Zone with VOC Contamination ...........................8

3.3 Deep Vadose Zone with SVOC Contamination ........................ 8

3.4 Deep Vadose/Groundwater Contamination ............................ 9

3.5 Restricted Access Contamination ................................... 10

4. Description of Baseline Technologies....................................... 11

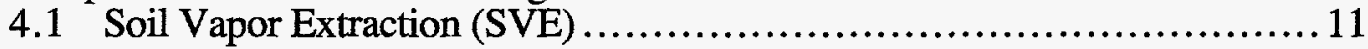

4.2 Pump \& Treat (P\&T) ............................................... 13

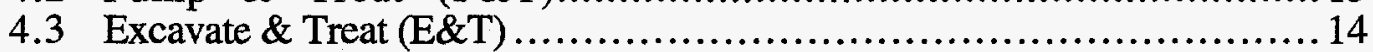

5. Emerging Technologies..................................................... 15

5.1 Overview ....................................................... 15

5.2 Low Frequency Heating (LF Heating) (Ohmic Heating) .................. 16

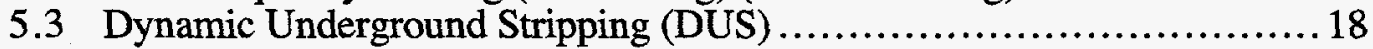

5.4 Radio Frequency Heating (RF) ..................................... 19

5.5 Radio Frequency Heating with Dipole Antennae (RFD) ................20

5.6 Thermally Enhanced Vapor Extraction System (TEVES)..................... 21

5.7 Contaminant Plume and Well Placement Geometry .................... 22

5.8 Choice of Baseline Technology ..................................... 23

5.9 Component Descriptions............................................ 24

5.9 .1 Vacuum System ........................................ 25

5.9 .2 Extraction Wells .......................................... 25

5.9 .3 Treatment System .........................................26

5.9.4 Water Source..................................................27

5.9.5 LF Application Wells ......................................28

5.9 .6 Power Source ................................................ 30

5.9 .7 Steam Source .............................................. 30

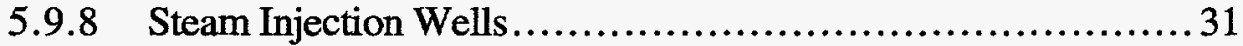

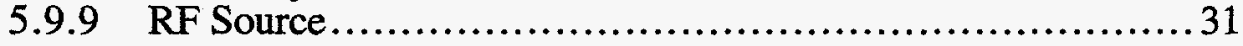

5.9.10 RF Application Wells .................................. 32

5.9.11 RF Dipole Application Wells.................................32

5.10 Monitoring the Remediation Process .................................. 33

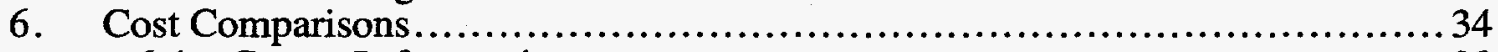

6.1 Cost Information................................................ 38

6.1.1 Scenario 1. Shallow Vadose Contamination.......................39

6.1.2 Scenario 2. Deep Vadose Zone with VOC Contamination....... 40

6.1.3 Scenario 3. Deep Vadose Zone with SVOC Contamination .....40

6.1.4 Scenario 4. Deep Vadose/Groundwater Contamination..........41

6.1.5 Scenario 5. Restricted Access Contamination ..................41

$7 \quad$ Future Developments and Technology Risks ................................. 42

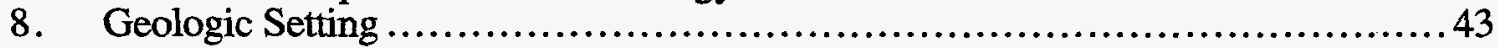

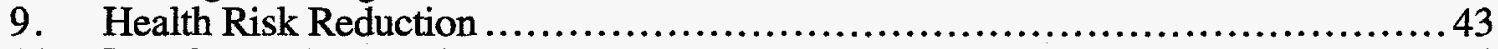

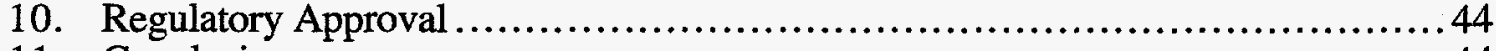

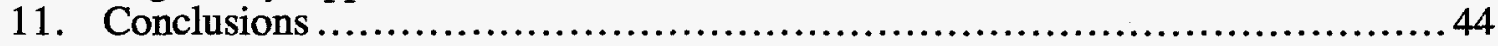

12. Bibliography .................................................................. 45

Appendix. Detailed Systems' Costs ............................................ 46 


\section{Figures}

Figure 1. Steps in Cost Comparison Analysis..................................6

Figure 2. Shallow Vadose Contamination.......................................... 8

Figure 3. Deep Vadose Contamination ......................................9

Figure 4. Deep Vadose and Groundwater Contamination......................... 10

Figure 5. Restricted Access Scenario Configuration............................. 11

Figure 6. SVE Major Subsystems............................................. 12

Figure 7. P\&T Major Subsystems .............................................. 13

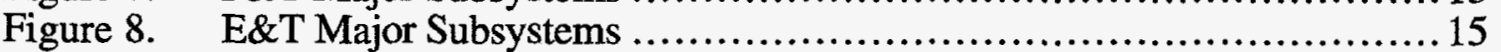

Figure 9. LF Major Subsystems............................................... 16

Figure 10. Contaminant Plume and Well Placement Geometry - Hexagonal Array .... 17

Figure 11. Contaminant Plume and Well Placement Geometry - Triplate Array ........ 17

Figure 12. DUS Major Subsystems .............................................. 19

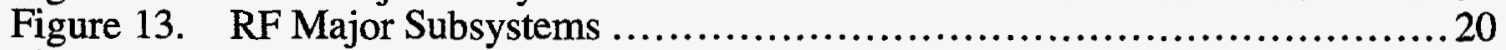

Figure 14. RFD Major Subsystems .............................................. 21

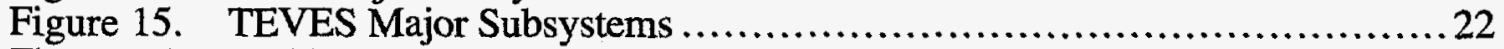

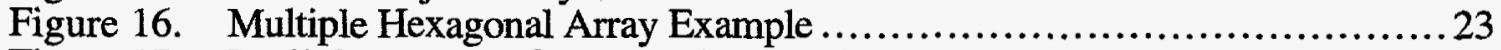

Figure 17. Well Diagrams for Baseline SVE System..............................26

Figure 18. Well Diagrams for Baseline SVE System in TEVES......................26

Figure 19. 6 Phase Conversion Network ......................................... 28

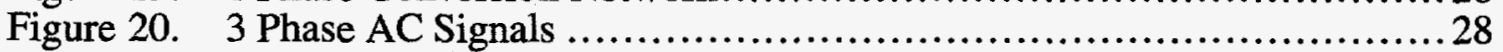

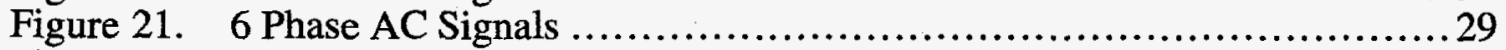

Figure 22. Well Diagram for Low Frequency (LF) Systems ...................... 30

Figure 23. Well Diagram for Low Frequency (LF) Injection Wells in TEVES ......... 30

Figure 24. Well Diagram for Dynamic Underground Stripping (DUS) System .......31

Figure 25. Well Diagram for Radio Frequency Application Well .......................32

Figure 26. Well Diagram for Radio Frequency Application Well in TEVES ...........32

Figure 27. Well Diagram for Radio Frequency Dipole Angled Application Well .......33

Figure 28. Contaminant Plume and TEVES Configuration...............................36

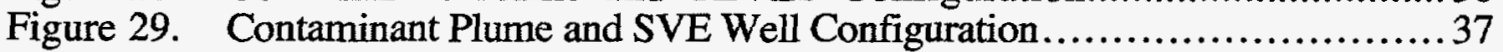

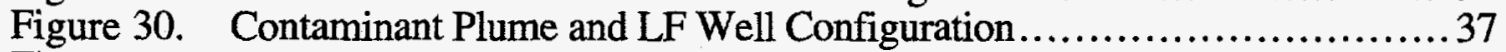

Figure 31. Contaminant Plume and RF Well Configuration..............................37

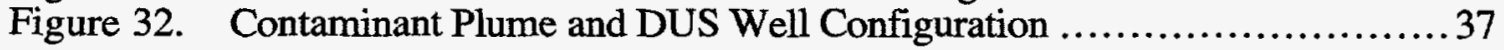

\section{Tables}

Table 1. Summary of Systems' Costs ......................................2

Table 2. A Review of the Scenarios and Technologies Studied in this Report............5

Table 3. Components and Technologies............................................24

\section{Glossary}

$\begin{array}{llll}\text { DUS } & \text { Dynamic Underground Stripping } & \text { RFD } & \text { Radio Frequency (Heating) Using Dipole Antennae } \\ \text { E\&T } & \text { Excavate \& Treat } & \text { SCFM } & \text { Standard Cubic Feet per Minute } \\ \text { LF } & \text { Low Frequency (Ohmic Heating) } & \text { SVE } & \text { Soil Vapor Extraction } \\ \text { ppb } & \text { parts per billion } & \text { SVOC } & \text { Semi-Volatile Organic Compound } \\ \text { ppm } & \text { parts per million } & \text { VOC } & \text { Volatile Organic Compound } \\ \text { P\&T } & \text { Pump \& Treat } & \text { VVE } & \text { Vapor Vacuum Extraction (also known as SVE) } \\ \text { RF } & \text { Radio Frequency (Heating) } & & \end{array}$




\section{Summary}

This report describes five thermally enhanced technologies that may be used to remediate contaminated soil and water resources. The standard methods of treating these contaminated areas are Soil Vapor Extraction (SVE), Excavate \& Treat (E\&T), and Pump \& Treat (P\&T). Depending on the conditions at a given site, one or more of these conventional alternatives may be employed; however, several new thermally enhanced technologies for soil decontamination are emerging. These technologies are still in demonstration programs which generally are showing great success at achieving the expected remediation results. The cost savings reported in this work assume that the technologies will ultimately perform as anticipated by their developers in a normal environmental restoration work environment.

The five technologies analyzed in this report are Low Frequency Heating (LF or Ohmic, both 3 and 6 phase AC), Dynamic Underground Stripping (DUS), Radio Frequency Heating (RF), Radio Frequency Heating using Dipole Antennae (RFD), and Thermally Enhanced Vapor Extraction System (TEVES). In all of these technologies the introduction of heat to the formation raises vapor pressures accelerating contaminant evaporation rates and increases soil permeability raising diffusion rates of contaminants. The physical process enhancements resulting from temperature elevations permit a greater percentage of volatile organic compound (VOC) or semivolatile organic compound (SVOC) contaminants to be driven out of the soils for treatment or capture in a much shorter time period.

This report presents the results of cost-comparative studies between these new thermally enhanced technologies and the conventional technologies, as applied to five specific scenarios. The results are summarized in the following tables which show that in every case the thermal technologies are significantly less expensive than the conventional technologies. The new thermal technologies save money by remediating the contaminants in about a 6-month-long campaign (our standard assumption for this report). The 6 months to remediate assumption is based upon typical, actual field test demonstration data from real remediation campaign projects with each of the thermally enhanced technologies. It is also supported by physical process modeling involving greatly accelerated contaminant evaporation due to vapor pressure elevation and soil permeability increases resulting from temperature rises. This accelerated removal due to heat application saves costs compared to many years of operations incurred with the conventional technologies. The thermal technologies typically involve expending a little more early capital expenses, but their 6-month total project lengths save large amounts of operating costs typical of the normal multiyear operating campaigns of the conventional technologies. The thermally enhanced technologies also facilitate the cleanup of contaminants from within tightly bound soils that frequently are impossible to remove through normal ambient temperature operating conditions. This is a major benefit in addition to the cost savings resulting from the much quicker cleanups. 
Table 1. Summary of Systems' Costs

\begin{tabular}{|c|c|c|}
\hline Shallow Vadose Co & tamination & \\
\hline Parameters & $\begin{array}{c}\text { TEVES } \\
\text { (RF \& } 3 \text { Phase) }\end{array}$ & $\begin{array}{l}\text { Excavate } \\
\text { and Treat }\end{array}$ \\
\hline Site-Specific Capital Equipment Cost & $\$ 464,800$ & $\$ 145,100$ \\
\hline & $\$ 99,400$ & $\$ 150,500$ \\
\hline Operation and Maintenance Cost & $\$ 215,100$ & $\$ 3,176,700$ \\
\hline Total Cost to Remediate & $\$ 779,300$ & $\$ 3,472,300$ \\
\hline Unit Cost per Cubic Yard & $\$ 130$ & $\$ 590$ \\
\hline $\begin{array}{l}\text { Cubic Yards } \\
\text { Time Frame }\end{array}$ & $\begin{array}{c}5,900 \\
6 \text { months }\end{array}$ & $\begin{array}{c}5,900 \\
12 \text { months }\end{array}$ \\
\hline
\end{tabular}

\begin{tabular}{|c|c|c|c|}
\hline Deep Vadose Zone & $\begin{array}{l}\text { VOC Cor } \\
3 \text { Phase } \\
\text { AC Soil } \\
\text { Heating }\end{array}$ & $\begin{array}{l}\text { ation } \\
6 \text { Phase } \\
\text { AC Soil } \\
\text { Heating }\end{array}$ & $\begin{array}{l}\text { Soil Vapor } \\
\text { Extraction }\end{array}$ \\
\hline \multirow{3}{*}{$\begin{array}{l}\text { Site-Specific Capital Equipment Cost } \\
\text { Reusable Capital Equipment Amortization Cost } \\
\text { Capital Equipment Amortization Cost } \\
\text { Operation and Maintenance Cost } \\
\qquad \text { Total Cost to Remediate } \\
\text { Unit Cost per Cubic Yard }\end{array}$} & $\begin{array}{c}\$ 535,300 \\
\$ 72,700 \\
\$ 101,700 \\
\end{array}$ & $\begin{array}{c}\$ 535,300 \\
\$ 89,900 \\
\$ 101,700 \\
\end{array}$ & $\begin{array}{l}\$ 634,800 \\
\$ 888,500 \\
\end{array}$ \\
\hline & $\$ 709,700$ & $\$ 726,900$ & $\$ 1,523,300$ \\
\hline & $\$ 24$ & $\$ 25$ & $\$ 53$ \\
\hline $\begin{array}{l}\text { Cubic Yards } \\
\text { Time Frame }\end{array}$ & $\begin{array}{c}29,000 \\
6 \text { months }\end{array}$ & $\begin{array}{c}29,000 \\
6 \text { months }\end{array}$ & $\begin{array}{l}29,000 \\
5 \text { years }\end{array}$ \\
\hline
\end{tabular}

\begin{tabular}{|c|c|c|}
\hline $\begin{array}{c}\text { Deep Vadose Zone with SVOC } \\
\text { Parameters } \\
\end{array}$ & $\begin{array}{l}\text { Contamination } \\
\text { Radio } \\
\text { Frequency } \\
\text { Heating }\end{array}$ & $\begin{array}{l}\text { Soil Vapor } \\
\text { Extraction }\end{array}$ \\
\hline $\begin{array}{l}\text { Site-Specific Capital Equipment Cost } \\
\text { Reusable Capital Equipment Amortization Cost } \\
\text { Capital Equipment Amortization Cost } \\
\text { Operation and Maintenance Cost }\end{array}$ & $\begin{array}{l}\$ 379,900 \\
\$ 113,900 \\
\$ 107,900 \\
\end{array}$ & $\begin{array}{c}\$ 634,800 \\
\$ 1,657,100 \\
\end{array}$ \\
\hline Total Cost to Remediate & $\$ 601,700$ & $\$ 2,291,900$ \\
\hline Unit Cost per Cubic Yard & $\$ 21$ & $\$ 79$ \\
\hline $\begin{array}{l}\text { Cubic Yards } \\
\text { Time Frame }\end{array}$ & $\begin{array}{c}29,000 \\
6 \text { months }\end{array}$ & $\begin{array}{c}29,000 \\
10 \text { years }\end{array}$ \\
\hline
\end{tabular}




\begin{tabular}{|c|c|c|}
\hline Deep Vadose Zone with Groun & $\begin{array}{l}\text { water Contamir } \\
\text { Dynamic } \\
\text { Underground } \\
\text { Stripping }\end{array}$ & $\begin{array}{l}\text { Son } \\
\text { Soil Vapor } \\
\text { Extraction } \\
\text { (Pump \& Treat) }\end{array}$ \\
\hline \multirow{3}{*}{$\begin{array}{l}\text { Site-Specific Capital Equipment Cost } \\
\text { Reusable Capital Equipment Amortization Cost } \\
\text { Capital Equipment Amortization Cost } \\
\text { Operation and Maintenance Cost } \\
\qquad \begin{array}{l}\text { Total Cost to Remediate } \\
\text { Unit Cost per Cubic Yard }\end{array} \\
\end{array}$} & $\begin{array}{l}\$ 703,800 \\
\$ 112,200 \\
\$ 274,800 \\
\end{array}$ & $\begin{array}{l}\$ 776,000 \\
\$ 888,500 \\
\end{array}$ \\
\hline & $\$ 1,090,800$ & $\$ 1,664,500$ \\
\hline & $\$ 38$ & $\$ 57$ \\
\hline $\begin{array}{l}\text { Cubic Yards } \\
\text { Time Frame }\end{array}$ & $\begin{array}{c}29,000 \\
6 \text { months }\end{array}$ & $\begin{array}{l}29,000 \\
5 \text { years }\end{array}$ \\
\hline
\end{tabular}

\begin{tabular}{|c|c|c|}
\hline Restricted Access Contamina & $\begin{array}{l}\text { on (beneath bui } \\
\text { Radio } \\
\text { Frequency } \\
\text { Dipole Heating }\end{array}$ & $\begin{array}{l}\text { ng) } \\
\text { Soil Vapor } \\
\text { Extraction } \\
\text { (Res. Access) }\end{array}$ \\
\hline \multirow{3}{*}{$\begin{array}{l}\text { Site-Specific Capital Equipment Cost } \\
\text { Reusable Capital Equipment Amortization Cost } \\
\text { Capital Equipment Amortization Cost } \\
\text { Operation and Maintenance Cost } \\
\qquad \begin{array}{l}\text { Total Cost to Remediate } \\
\text { Unit Cost per Cubic Yard }\end{array}\end{array}$} & $\begin{array}{c}\$ 258,800 \\
\$ 79,600 \\
\\
\$ 107,900 \\
\end{array}$ & $\begin{array}{l}\$ 557,500 \\
\$ 888,500 \\
\end{array}$ \\
\hline & $\$ 446,300$ & $\$ 1,446,000$ \\
\hline & $\$ 890$ & $\$ 2,900$ \\
\hline $\begin{array}{l}\text { Cubic Yards } \\
\text { Time Frame }\end{array}$ & $\begin{array}{c}500 \\
6 \text { months }\end{array}$ & $\begin{array}{c}500 \\
5 \text { years }\end{array}$ \\
\hline
\end{tabular}

Notes on Table 1:

(1) "Site-Specific Capital Equipment Cost" refers to initial capital costs that are not transferable to any subsequent project (well drilling, mobilization, etc.). Usual analysis wraps these capital costs up with all other capital equipment and amortizes them over several years of project life. Because the thermal technology campaigns are less than a year in length, it is important to separate these costs from the "Reusable Capital Equipment" (water treatment skid, SVE skid, RF system, etc.). Reusable equipment will be used at other, future remediation locations and its cost is amortized over a five-year operating lifetime.

(2) "Capital Equipment Amortization Cost" is the normal roll-up of all capital expenditures for long-lived projects. This cost category is used for all of the conventional SVE technologies. Here the multiyear SVE campaigns do not have to concern themselves with the fact that wells and such are usable only at one specific site. These costs are captured/amortized over many years of operation because they are not in use only for a few months as is the unique case for the thermally enhanced technologies.

(3) "Unit Costs per Cubic Yard" should not be compared among/across the five different scenarios. Both baseline and thermally enhanced technologies have been matched to the specific scenarios for technology choice relevance and comparisons are only appropriate within each scenario. The remediation site scenarios are sufficiently 
different that it is not fair to compare specific technology cost estimates between remediation situations.

\section{Introduction}

One of the most difficult challenges facing the Department of Energy (DOE), the Department of Defense (DOD) and private industry today is the remediation of contaminated soil and water resources. The standard methods of treating these contaminated areas often do not work well, or are too slow or too expensive to be practical. The conventional technologies that are currently in use are Soil Vapor Extraction (SVE), Excavate \& Treat (E\&T), and Pump \& Treat (P\&T). Depending on the conditions at a given site, one or more of these conventional alternatives may be employed; however, several new technologies for soil decontamination are currently emerging. The five technologies that will be discussed in this report are similar to SVE, but introduce added energy to produce heat into the formation. These technologies are Low Frequency Heating (LF or Ohmic), Dynamic Underground Stripping (DUS), Radio Frequency Heating (RF), Radio Frequency Heating using Dipole Antennae (RFD), and Thermally Enhanced Vapor Extraction System (TEVES), a combination of LF and RF. Each of these technologies can be coupled with SVE and applied to a subset of the formation and contaminant plume types, in order to improve performance.

The introduction of heat to the formation permits a much greater percentage of volatile organic compound (VOC) contaminants to be recovered per unit of time, or, depending on the specific new technology being used permits a greater percentage of semivolatile organic compound (SVOC) contaminants to be recovered. Not only is contaminant extracted from the formation more completely, but it is also extracted much faster. VOCs (TCE, TCA, PCE, etc.) are characterized by relatively low vaporization temperatures, typically below $100^{\circ} \mathrm{C}$ at atmospheric pressure. SVOCs (pesticides, PCBs, etc.) are characterized by having higher vaporization temperatures, typically greater than $100^{\circ} \mathrm{C}$ at atmospheric pressure.

In this report we will present the results of cost-comparative studies between the new thermally enhanced technologies and the conventional technologies, as applied to five specific scenarios. As a result of this study, managers will be guided to make technology choices based on cost data and specific site characteristics. 
Table 2. A Review of the Scenarios and Technologies Studied in this Report

\begin{tabular}{|c|c|c|c|}
\hline Scenario & Description & $\begin{array}{l}\text { Innovative } \\
\text { Technology }\end{array}$ & $\begin{array}{c}\text { Baseline } \\
\text { Technology }\end{array}$ \\
\hline $\begin{array}{l}\text { 1: Shallow Vadose } \\
\text { Contamination }\end{array}$ & $\begin{array}{l}\text { VOC and SVOC contamination } \\
\text { has occurred due to a spill or } \\
\text { leak at the surface. Affected } \\
\text { areas include the soil at the } \\
\text { surface, and the vadose zone } \\
\text { area to a depth of } 20 \text { feet. }\end{array}$ & $\begin{array}{l}\text { Thermally } \\
\text { Enhanced } \\
\text { Vapor } \\
\text { Extraction } \\
\text { System } \\
\text { (TEVES) }\end{array}$ & $\begin{array}{l}\text { Excavate and } \\
\text { Treat }\end{array}$ \\
\hline $\begin{array}{l}\text { 2: Deep Vadose } \\
\text { Zone with VOC } \\
\text { Contamination }\end{array}$ & $\begin{array}{l}\text { VOC contamination as the result } \\
\text { of a leaking underground storage } \\
\text { tank (located } ~ 20 \text { feet below the } \\
\text { surface). Contaminants have } \\
\text { caused a cone shaped plume that } \\
\text { has penetrated a layer of clay. }\end{array}$ & $\begin{array}{l}\text { Low } \\
\text { Frequency } \\
\text { Heating }\end{array}$ & $\begin{array}{l}\text { Soil Vapor } \\
\text { Extraction }\end{array}$ \\
\hline $\begin{array}{l}\text { 3: Deep Vadose } \\
\text { Zone with SVOC } \\
\text { Contamination }\end{array}$ & $\begin{array}{l}\text { SVOC contamination as the } \\
\text { result of a leaking underground } \\
\text { storage tank (located } \sim 20 \text { feet } \\
\text { below the surface). } \\
\text { Contaminants have caused a } \\
\text { cone shaped plume that has } \\
\text { penetrated a layer of clay. }\end{array}$ & $\begin{array}{l}\text { Radio } \\
\text { Frequency } \\
\text { Heating }\end{array}$ & $\begin{array}{l}\text { Soil Vapor } \\
\text { Extraction }\end{array}$ \\
\hline $\begin{array}{l}\text { 4: Deep Vadose/ } \\
\text { Groundwater } \\
\text { Contamination }\end{array}$ & $\begin{array}{l}\text { Similar to the scenario for deep } \\
\text { vadose zone contamination with } \\
\text { the addition of groundwater. } \\
\text { The groundwater table is located } \\
100 \text { feet below soil surface. }\end{array}$ & $\begin{array}{l}\text { Dynamic } \\
\text { Underground } \\
\text { Stripping }\end{array}$ & $\begin{array}{l}\text { Soil Vapor } \\
\text { Extraction } \\
\text { with Pump } \\
\text { and Treat }\end{array}$ \\
\hline $\begin{array}{l}\text { 5: Restricted } \\
\text { Access } \\
\text { Contamination }\end{array}$ & $\begin{array}{l}\text { SVOC contamination has } \\
\text { occurred beneath a structure due } \\
\text { to a leaking pipe. The structure } \\
\text { limits access to the plume. }\end{array}$ & $\begin{array}{l}\text { Radio } \\
\text { Frequency } \\
\text { Heating with a } \\
\text { Dipole } \\
\text { Antennae }\end{array}$ & $\begin{array}{l}\text { Soil Vapor } \\
\text { Extraction } \\
\text { (Restricted } \\
\text { Access) }\end{array}$ \\
\hline
\end{tabular}

\section{Methodology}

The methodology used to evaluate the cost effectiveness of a new environmental technology comprises both a performance evaluation and an economic evaluation; however, given the multitude of site specific variables, i.e., lithology, contaminants, etc., a performance evaluation for each technology would be too limiting. Instead, the authors of this report have collected cost data for each technology. Based on this data, a monthly cost for building and operating a technology system, managers at each site can be guided towards which technology might meet their site needs. The steps of the methodology are shown in Figure 1. The new environmental technologies will be compared to baseline technologies currently in use. We are addressing the question: "For the remediation of soils contaminated by chlorinated solvents, VOCs, and SVOCs, 
how much money does it cost to build and operate thermally enhanced extraction systems instead of conventional technologies?"

Figure 1. Steps in Cost Comparison Analysis

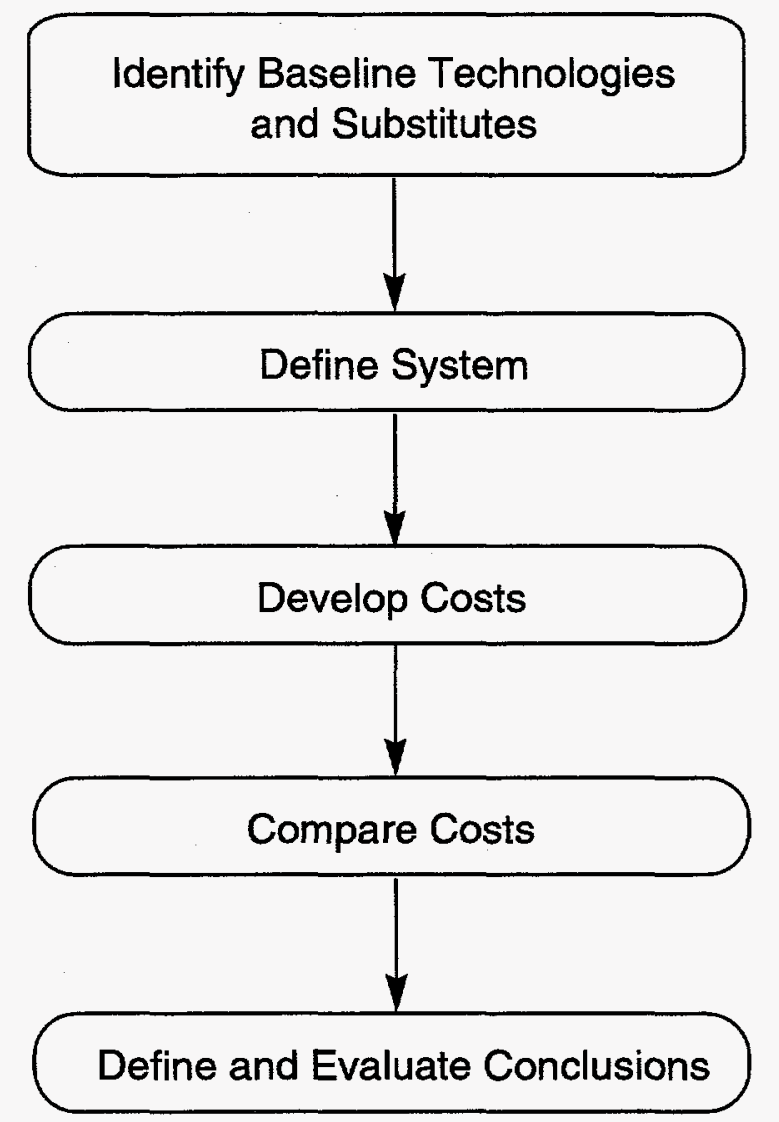

A fundamental issue in evaluating a new environmental technology is to address the question, "What does one compare the new technology to?". It is important to note that in many cases a new environmental technology does not specifically replace some current technology or practice on a one-to-one basis. Thus, we will look at a range of baseline technologies, if necessary, to reasonably consider the actual role of the new environmental remediation technology. The major components of the methodology are:

- Identify major cost characteristics of the new environmental technology.

- Identify appropriate conventional technologies to serve as the baseline for cost comparisons with the new technology.

- Compare costs between the new technology and the conventional alternatives.

- Use scenarios to provide a realistic context for the cost comparison. 
- Consider all other relevant aspects and/or effects involved in the use of the new environmental technology. When it is not possible to consider these influences in scenarios due to a lack of detailed information, a qualitative discussion is given. Important issues are: future developments expected in both the new technology and conventional alternatives, applicability of the new technology to different geologic settings, applicability of the new technology to different types of waste sites, health risk and environmental risk reduction, and regulatory status and perceived public acceptance.

We intend for this report to be a useful tool for managers of DOE environmental restoration programs, government agencies and private industry. However, the reader will need to pay careful attention to caveats discussed in this report, such as applicable geologic setting, to determine how this technology might best be utilized at a particular environmental restoration site. It is beyond the scope of this report to consider all possible scenarios. Consequently, the descriptive approach provides the most general use for the DOE community. Any and all applicable characteristics associated with a specific site are significant factors needed to determine the outcome and evidential success of any environmental remediation technology.

\section{Description of Scenarios}

In order to demonstrate the treatment capabilities of each of the technologies in this study, five typical contamination scenarios are presented for evaluation. The scenarios include shallow vadose contamination, deep vadose zone with VOC contamination, deep vadose zone with SVOC contamination, deep vadose and groundwater contamination, and contamination where there is restricted access to the plume. All of the scenarios are based on a hypothetical leaking source that allowed the contaminant to enter the subsurface. With the exception of Scenario 5, the geology is assumed to have a layer of clay in the midst of the deep contaminated soil, decreasing the permeability of the formation. The contaminant is assumed to be a combination of VOCs, such as TCE (trichloroethylene) or BTEX (benzene, toluene, ethyl benzene and xylene- the major components of gasoline) and SVOCs, such as PCBs (polychlorinated biphenyls) and pesticides. The inclusion of the layer of clay in the scenario descriptions is intended to assist in demonstrating the benefits of thermally enhanced vapor extraction. Contaminants, particularly solvents, can become trapped in relatively impermeable layers of clay, thus limiting the success of conventional SVE methods. 


\subsection{Shallow Vadose Contamination}

The scenario for shallow vadose zone contamination is one where contamination (assumed to be both VOCs and SVOCs) of the soil has occurred due to a spill or leak at the surface. The affected areas include the soil at the surface, radiating outward from the source, and the vadose zone immediately under the contaminated area to a depth of 20 feet. The total volume of contaminated soil is approximately $5,900 \mathrm{cy}$. Figure 2 represents this scenario. The conventional excavate and treat method will be used as the baseline for comparison to the TEVES system for the treatment of shallow vadose contamination.

Figure 2. Shallow Vadose Contamination

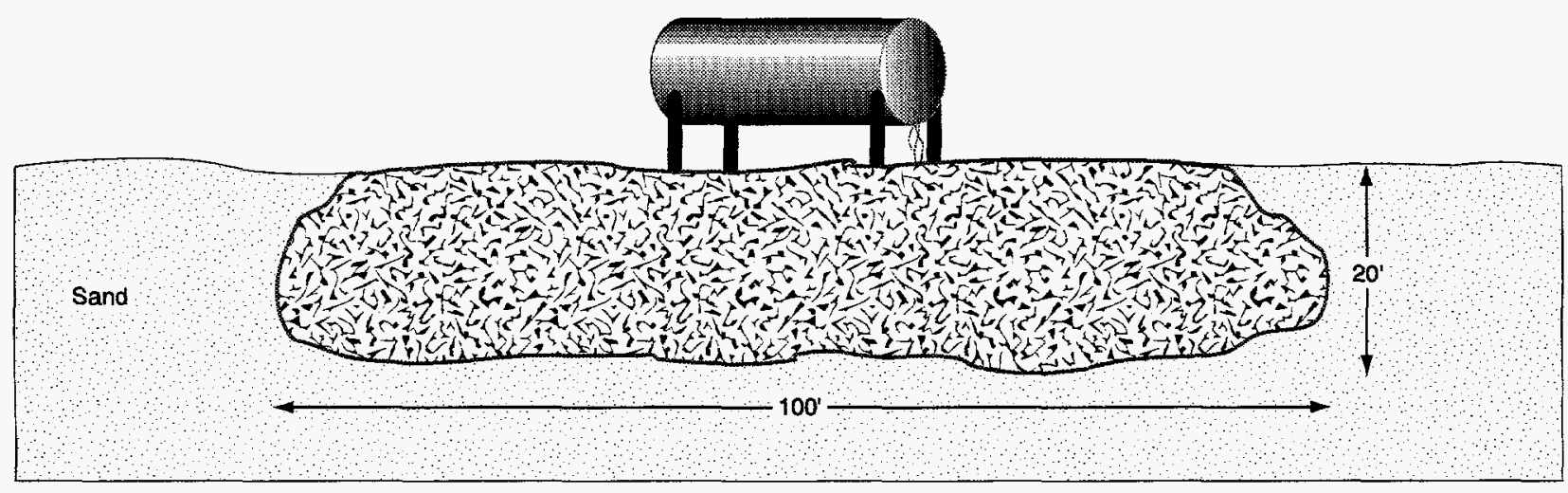

Total Volume Remediated $\approx 5,900 \mathrm{cy}$

\subsection{Deep Vadose Zone with VOC Contamination}

The scenario for deep vadose zone with VOC contamination is one where contamination of the soil has occurred as the result of a leaking underground storage tank. The storage tank is located approximately 20 feet below the surface. The VOC contaminants have migrated down and out resulting in a cone shaped plume with a depth of 100 feet and a base diameter of 90 feet. The plume has penetrated a 20 foot thick layer of clay approximately 40 feet beneath the damaged tank. The total volume of VOC contaminated soil is approximately 29,000 cy. Figure 3 represents this scenario. Conventional SVE will be used as the baseline for comparison to three phase soil heating and six phase soil heating, and RF heating for the treatment of deep vadose contamination.

\subsection{Deep Vadose Zone with SVOC Contamination}

Scenario 3 is deep vadose zone with SVOC contamination. In this case, the soil is contaminated as the result of a leaking underground storage tank. The storage tank is located approximately 20 feet below the surface, and the SVOC contaminants have migrated down and out 
resulting in a cone shaped plume with a depth of 100 feet and a base diameter of 90 feet. The plume has penetrated a 20 foot thick layer of clay approximately 40 feet beneath the damaged tank. The total volume of SVOC contaminated soil is approximately 29,000 cy. Figure 3 also represents this scenario. Conventional SVE will be used as the baseline for comparison to RF heating for the treatment of deep vadose with SVOC contamination.

Figure 3. Deep Vadose Contamination

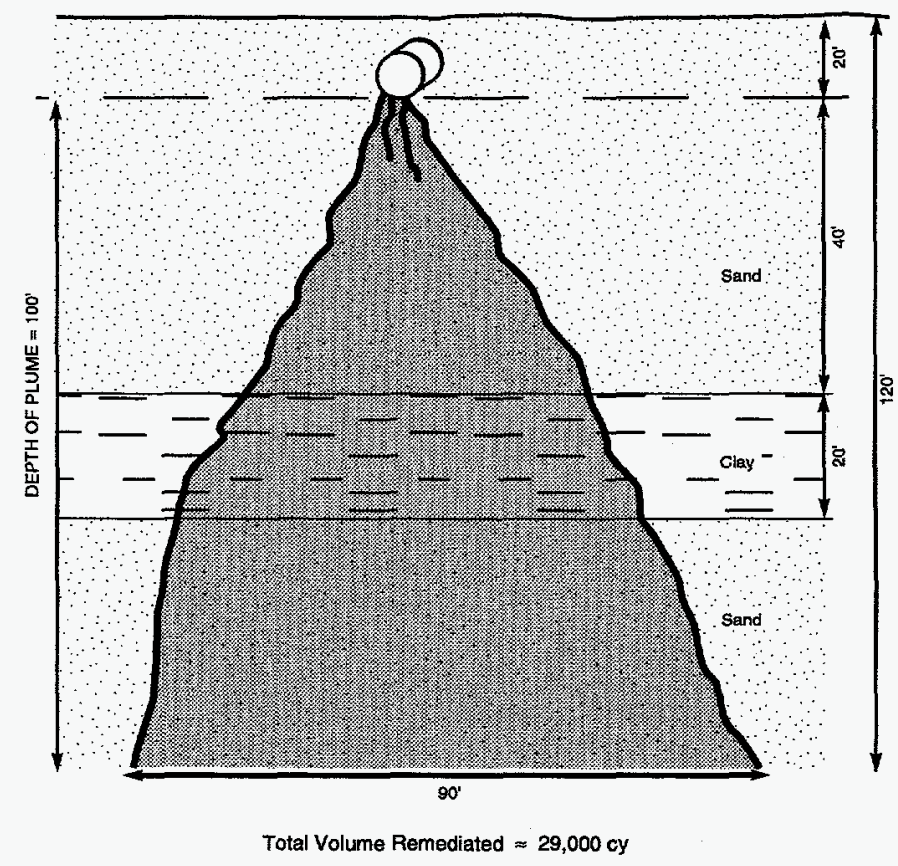

\subsection{Deep Vadose/Groundwater Contamination}

The scenario for deep vadose/groundwater contamination is similar to the scenario developed for deep vadose contamination with the addition of contaminated groundwater. The groundwater table is located 100 feet below soil surface ( 80 feet below the damaged tank). Figure 4 represents this scenario. Conventional SVE combined with pump and treat will be used as the baseline for comparison to DUS for the treatment of deep vadose and groundwater contamination. 
Figure 4. Deep Vadose and Groundwater Contamination

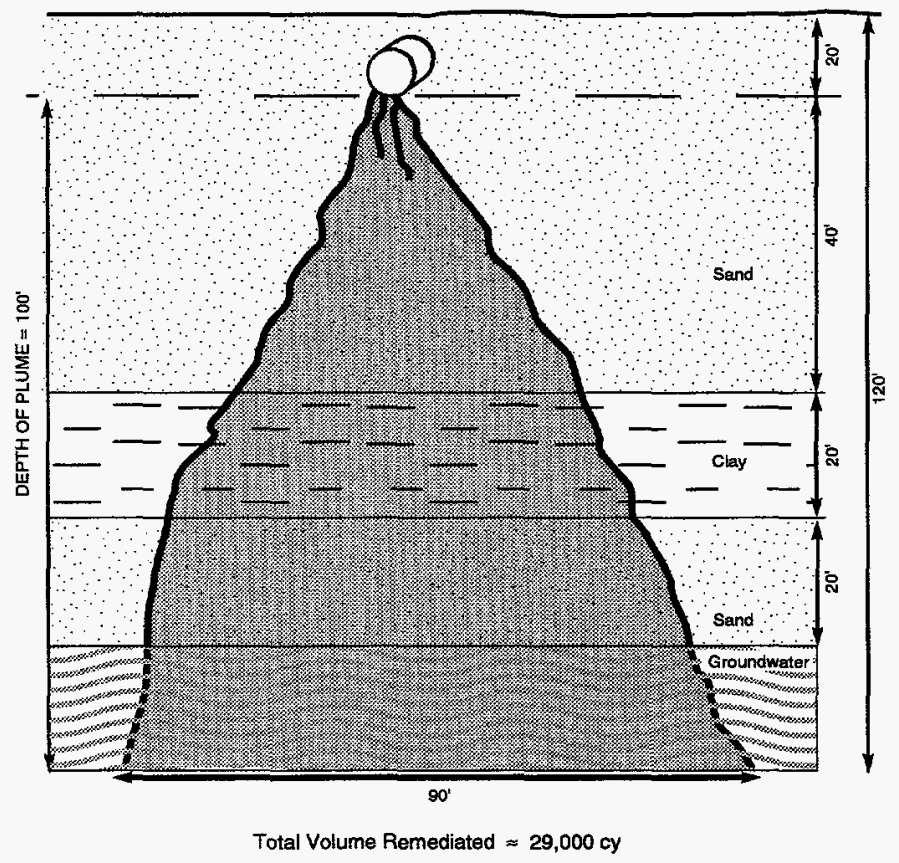

\subsection{Restricted Access Contamination}

The scenario for restricted access contamination is one where SVOC contamination has occurred beneath a structure due to a leaking pipe. The presence of the structure limits the access to the plume such that the plume can only be penetrated from an angle. Figure 5 represents this scenario. Conventional SVE methods will be used as the baseline for comparison to RFD for the treatment of contaminated soil subject to restricted access. 


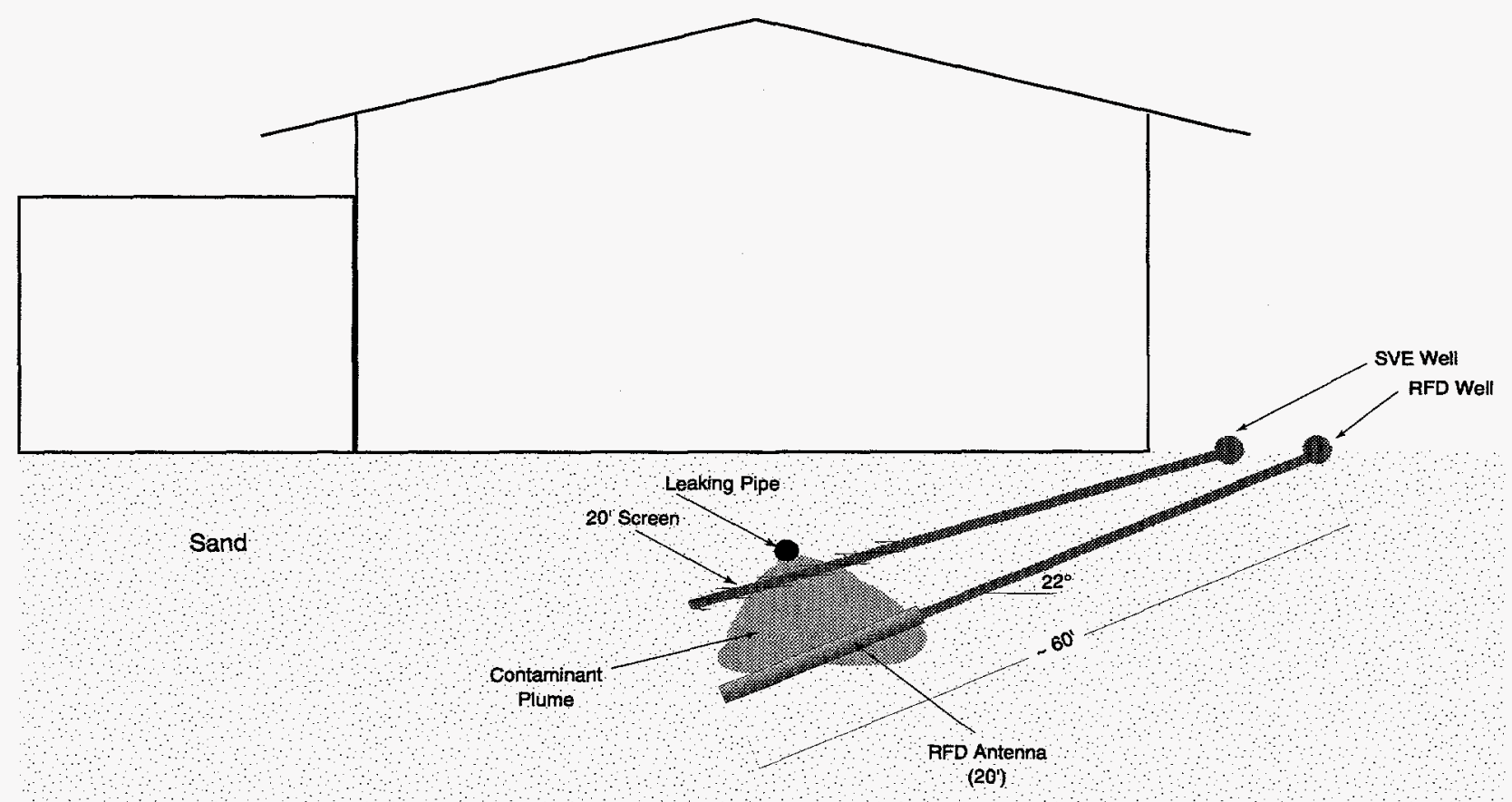

\section{Description of Baseline Technologies}

The methods currently in wide-spread use for soil decontamination are SVE, E\&T, and P\&T. Each technique can be applied judiciously depending on the conditions at the site where the remediation is to be performed. These three techniques will be described here. The choice of the technology to be used as the baseline for each scenario, as well as the rationale for this choice, will be given at the end of Section 4. Please note that while we attempted to determine the advantages and disadvantages for a given technique, we cannot guarantee that the lists given are exhaustive. We do believe, though, that the lists given are representative.

\subsection{Soil Vapor Extraction (SVE)}

Soil Vapor Extraction is the simplest method currently in use for the remediation of organic contamination of the vadose zone. This technique relies on a small partial vacuum established in a well to provide an air sweep of the contaminant plume. The hardware required for this method consists of: the extraction well(s), a vacuum pump attached to one or more wells (which are drilled into the plume), an off-gas treatment facility such as a catalytic oxidation system (catox), and a 
means of disposing of any other waste material. A functional description of SVE is shown in Figure 6.

Figure 6. SVE Major Subsystems

(Arrows indicate the flow of vapor.)

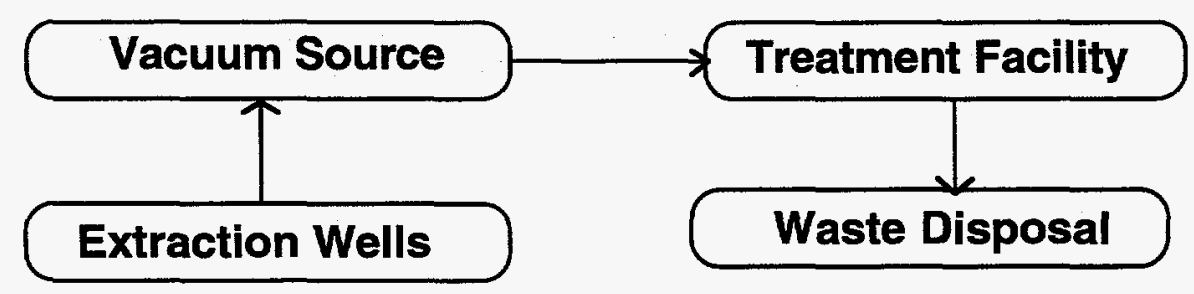

The way that SVE operates is very straight-forward. Once the well(s) is in place and the vacuum system and off-gas treatment facility are installed and operating, the vacuum will cause an air sweep in the contaminant plume towards the extraction well(s). The air sweep carries with it some of the contaminant in the form of a gas or vapor. This vapor is then drawn up the well(s) and directed to an off-gas treatment facility (such as a catox system or other suitable facility) where the contaminant vapors are destroyed.

Once the well(s) is drilled and the necessary equipment is connected to form the overall system, there is little labor required. The bulk of the labor is in preventive maintenance of the equipment and periodic sampling of the exhaust gasses to determine the level of contaminant left in the formation. Once the desired level of decontamination is reached (that is, once the extracted vapor reaches the desired level of remediation) the system may be turned off. Periodic monitoring is still required, especially if the formation contains any clay or other low permeability components. If this periodic monitoring indicates that the level of contamination has risen to above the desired level, the system is turned on again until the contamination level has again reached the desired point. This cycle of turning the system on and off continues until such time as the desired contaminant level on the formation is reached and maintained over a long period of time (measured in numbers of years).

The advantages of SVE include:

- minimal operator intervention

- system simplicity

- low capital equipment cost

- works well in permeable layers of the vadose zone

- minimal risk to the people working at the site

- minimal risk to the environment

- minimal risk of collateral damage to the indigenous population 
The disadvantages of SVE include:

- long treatment times, especially in low-permeable geologies

- high overall cost due to long treatment durations

- minimal effect on clay or other low permeability layer

- minimal effect on SVOCs

- not appropriate for remediation of groundwater

- susceptible to weather conditions in the long term; annual snow melt and rain fall tend to leach contaminants from low permeability layers, possibly for a very long time period

\subsection{Pump \& Treat (P\&'T)}

Pump \& Treat is also a simple remediation method. This technique relies on a water pump to draw water from the contaminated aquifer through a well, directing the water to a water treatment facility. The equipment needed for this method consists of: a water pump attached to one or more extraction wells positioned downstream of the contaminant plume, a water treatment facility designed to decontaminate the water, a means of disposing of any waste that is collected, and one or more injection wells, or a surface discharge unit, for returning the decontaminated water back to the aquifer slightly upstream of the contaminant plume. A functional diagram of this type of remediation is presented in Figure 7 below.

Figure 7. P\&T Major Subsystems

(Arrows indicate the flow of water.)

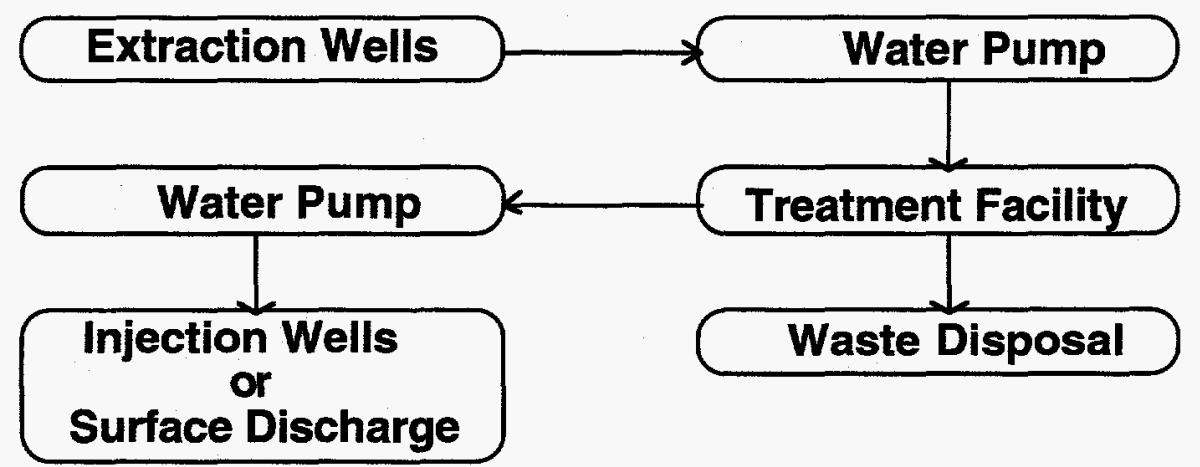

Again, once the wells are drilled and the necessary equipment is connected to form the overall system, there is little labor required. The bulk of the labor is in preventive maintenance of the equipment and periodic sampling of the extracted water to determine the level of contaminant left in the formation. Once the desired level of decontamination is reached (that is, once the extracted water reaches the desired level of remediation) the system may be turned off. Periodic 
monitoring is still required, especially if the formation contains any clay or other non-permeable components. If this periodic monitoring indicates that the level of contamination has risen above the desired level, the system is turned on again until the contamination level has again reached the desired point. This cycle of turning the system on and off continues until such time as the desired contaminant level in the formation is reached and maintained over many years.

The advantages of P\&T include

- minimal operator intervention

- $\quad$ system simplicity

- low capital equipment cost

- applicable to groundwater remediation

- minimal risk to the people working at the site

- minimal risk to the environment

- minimal risk of collateral damage to the indigenous population

The disadvantages of P\&T include

- long treatment durations

- high overall cost due to long treatment durations

- not appropriate for remediation of vadose zone.

- the contaminant must reach the water table before it can be removed

- susceptible to weather conditions in the long term; annual snow melt and rain fall tend to leach contaminants from low permeability layers, possibly for a very long time period

\subsection{Excavate \& Treat (E\&T)}

Excavate \& Treat is a labor intensive method of treating contaminated soils. In a remediation effort that uses the E\&T method, the contaminated soil is excavated from the ground and delivered to a treatment facility for destruction or immobilization of the contaminants. A functional block diagram of E\&T is given in Figure 8. The equipment necessary includes heavy equipment for excavating the soil, a means of transporting the soil to a treatment facility, the treatment facility itself, and, possibly, a means of returning the treated soil to the excavation site. If the treated soil cannot be put back into the excavation, clean backfill must be obtained and placed into the excavation. The benefit of this type of remediation is that it completely removes all of the contaminant in the plume, hence there is no long term monitoring effort required. 
Figure 8. E\&T Major Subsystems

(Arrows show the flow of soil.)

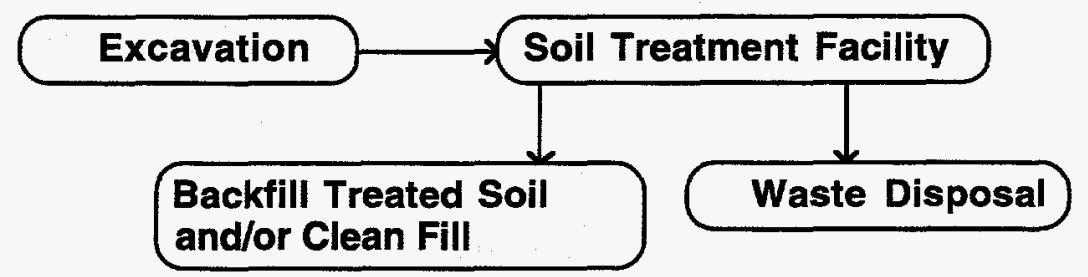

The advantages of E\&T include

- system simplicity

- better effect on clay or other low permeability layers as well as the more permeable layers of the vadose zone

- total removal of the contaminant plume

The disadvantages of E\&T include

- labor intensive

- higher risk to the people working at the site

- high overall cost due to labor, capital equipment and safeguards

- severe ecosystem destruction

- higher risk of collateral damage to the indigenous population

- effective in shallow applications only

\section{Emerging Technologies}

\subsection{Overview}

The emerging technologies to be presented in this report are Low Frequency Heating (LF), Dynamic Underground Stripping (DUS), Radio Frequency Heating (RF) and Radio Frequency Heating with Dipole Antennae (RFD), and a combination of LF plus RF, known as the TEVES technology system. The purpose of soil heating is to raise the bulk temperature of a soil to assist in the removal of organic contaminants by conventional soil vapor extraction (SVE). In ideal conditions, SVE would have rapid remediation times; however, tailing behavior is observed at nearly all remediation sites. Initially high concentrations of contaminant fall off rapidly after the first few days or weeks to rather steady concentrations for the rest of the remediation period (Rosenberg 1995).

Heating a soil can be beneficial when the contaminant of interest is not volatile enough to enable its timely removal by venting with air. Vapor pressures, diffusion, solubility, and chemical reaction rates all tend to increase with increasing temperature. Heating effectively increases the 
vapor pressure of the contaminant, which increases its rate of removal. Soil heating adds additional benefits when soil temperatures are raised to the boiling point of the indigenous soil moisture. Boiling moisture creates an in situ source of steam that can strip less volatile organics from soils -- organic compounds that otherwise would not be removed by venting alone. Removal of soil moisture (as steam) also tends to increase the flow permeability of soils, which can further increase the rate of contaminant removal by simultaneous SVE. Compared to other methods such as steam or hot-air injection, applied electrical fields have the advantage of heating soils internally, where the soil itself acts as the heat source. Consequently, electrical field heating is not adversely affected by low flow permeability. This characteristic suggests that electrical heating, combined with SVE, may provide a way to decontaminate low-permeability soils like silts or clays (Heath et al. 1992).

\subsection{Low Frequency Heating (LF Heating) (Ohmic Heating)}

LF heating requires the installation of one or more electrode arrays wide enough and deep enough to encompass the contaminated volume. A power system must provide sufficient voltage to each electrode array to enable a predetermined amount of power to be delivered to the soil. The amount of power required depends on many factors, but will typically be in the range of 300 to $1000 \mathrm{kwh} / \mathrm{m}^{3}$ of soil heated. The major subsystems for LF are shown in Figure 9.

Figure 9. LF Major Subsystems

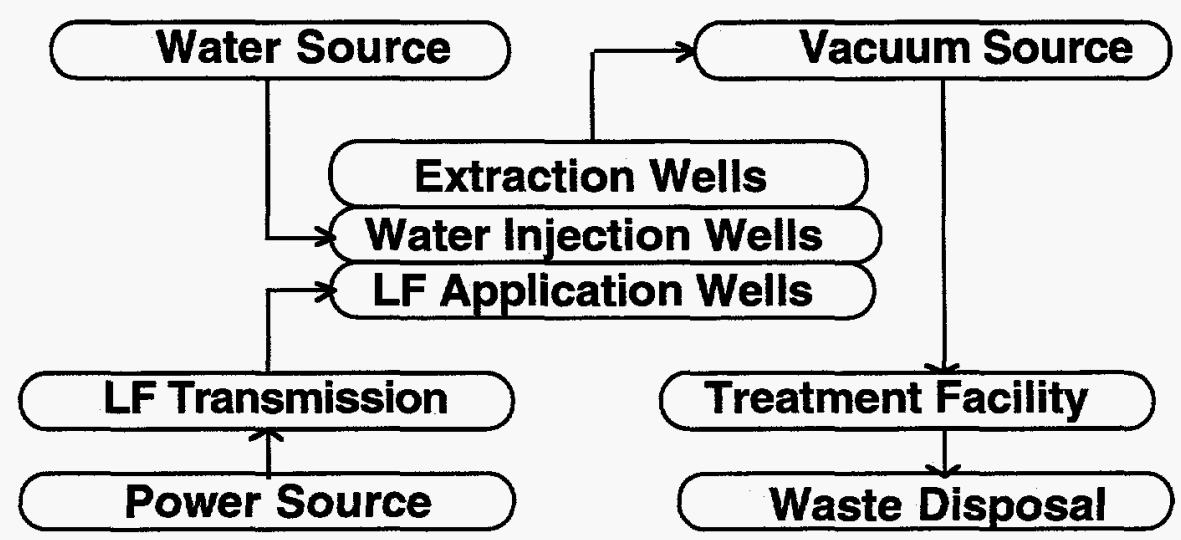

The electrode array(s) can take on one of two general configurations. One configuration is a hexagonal array of 15 - $50 \mathrm{ft}$. in radius, as displayed in Figure 10. In this configuration, the electrical energy is applied using three or six phase AC current to the electrodes located in the wells labeled A-F at the apexes of the hexagon. The well marked $\mathrm{Z}$ is used as the extraction well. Small amounts of water may be introduced into the formation from any of the wells in order to maintain an electrically traversable path within the formation. 
Figure 10. Contaminant Plume and Well Placement Geometry - Hexagonal Array

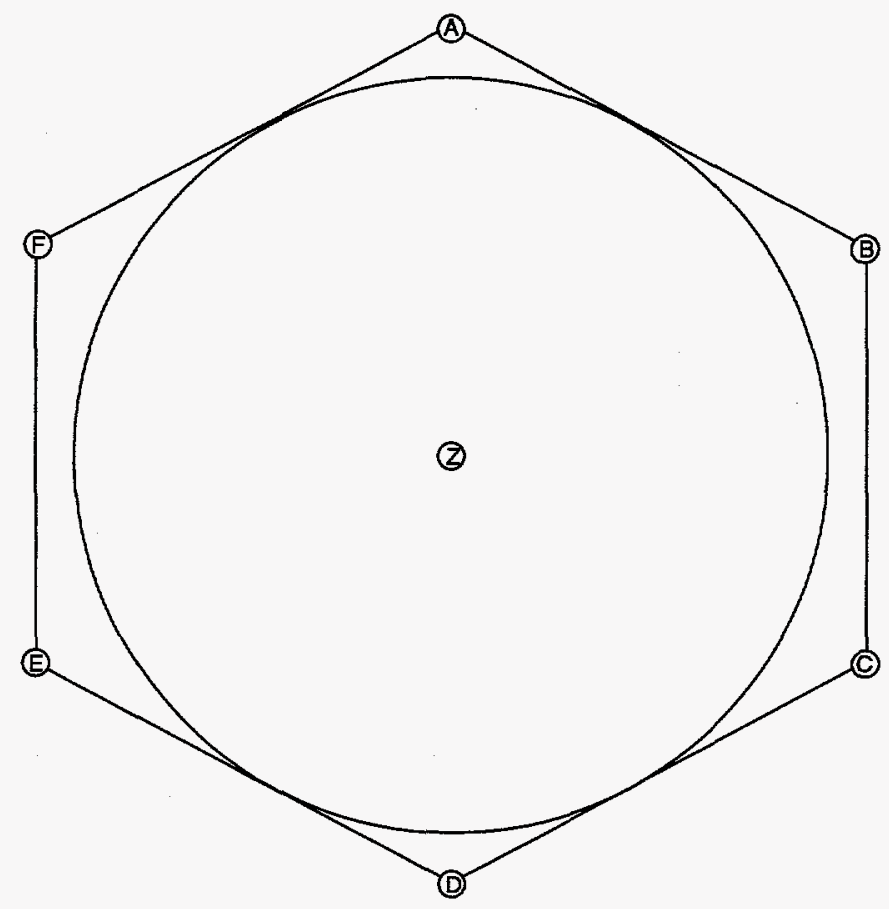

A second configuration currently being tested is a rectangular array, called a "triplate array," where current is introduced at the center of the formation, and a set of guard, or electrically grounded, electrodes are placed at the outside edges of the formation. This type of array is shown in Figure 11.

Figure 11. Contaminant Plume and Well Placement Geometry - Triplate Array

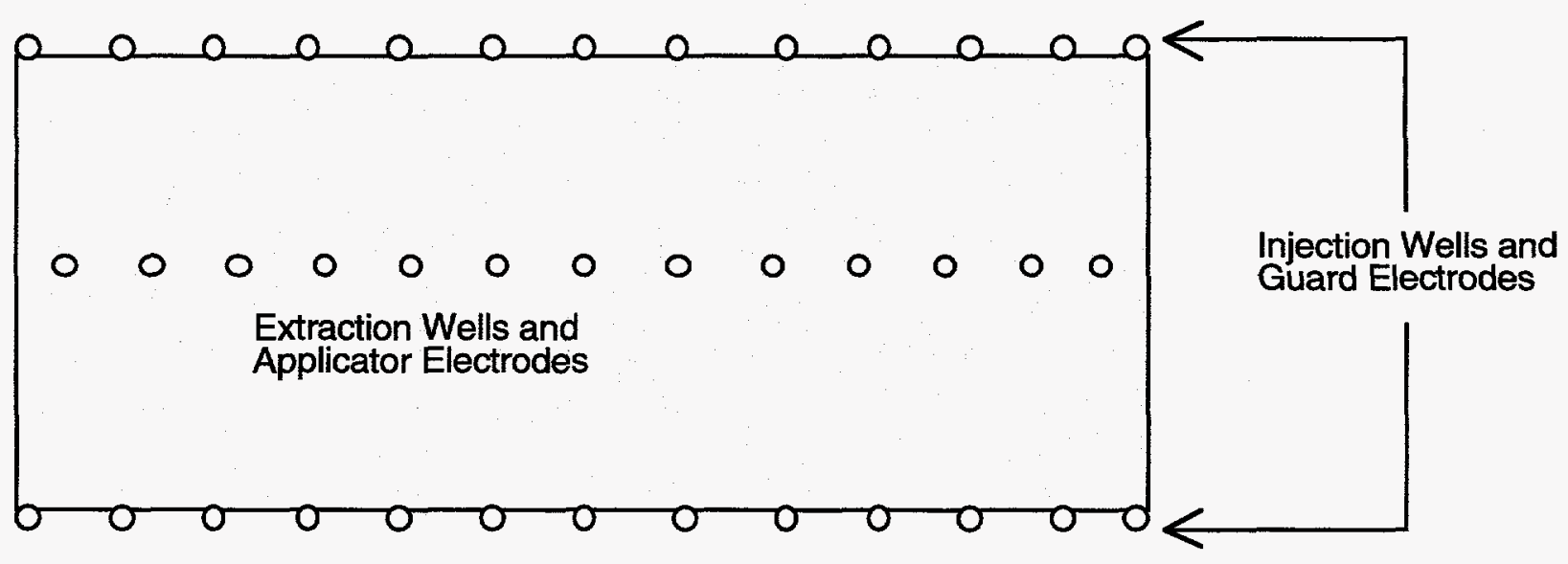


Low frequency heating consists of a standard SVE configuration with the added functional components necessary to deliver large amounts of electrical energy, as well as small amounts of water to the formation. The water in the formation is absolutely necessary to this technology as it is the source of electrical conduction. Once the formation reaches the boiling point of water, the water that is removed by the extraction wells as steam must be replaced in order to continue to use LF heating to augment SVE. This caveat is an important consideration if the formation contains any contaminated low permeability layers. Once the moisture in these layers is driven off, LF heating will stop. Without using any type of system designed to reintroduce water into these layers, the LF contaminant removal process cannot have any further direct effect on these layers. As we shall see, there is another method currently under development to aid in the solution of this problem, RF heating. LF heating is not particularly effective in driving out SVOCs with their boiling points above the boiling point of water as the boiling off of water prevents reaching higher temperatures. But the higher temperature possibilities with RF heating (not dependent on water conductivity to deliver energy to the soil) can address the SVOC volatilization points more directly.

\subsection{Dynamic Underground Stripping (DUS)}

To heat clay layers for remediation, DUS uses Ohmic heating, where the clay layers themselves act as the heating element when large currents are driven through them. This technique targets the clay-rich layers which are not well penetrated by steam injection and should be self limiting; as the clays heat up and dry out, current will stop flowing. In a typical application, the concentrated plume would be surrounded by injection wells, with one or more extraction wells located in the center. The injection wells would be screened in the more permeable areas, and in less permeable areas the well would be completed for electrical current (conductive packing material and a stainless steel electrode). Remediation starts with pumping the extraction wells to depress the water table in the center of the pattern, followed by steam injection at 50-60 psi.

As steam is forced into the formation, the earth is heated to the boiling point of water. The advancing pressure front displaces ground water toward the extraction well. Near the steamcondensate front, organics are distilled into the vapor phase, transported to the steam condensation front, and condensed there. The advancing steam zone displaces the condensed liquids toward the recovery well where they are pumped to the surface. At this point in the process not all of the contaminated sediments may have been contacted by steam. Electrode assemblies placed in the impermeable layers are turned on, passing $480 \mathrm{~V}$ current at several hundred amperes per electrode. This heats the clay and fine-grained sediments and causes water and contaminants trapped within to vaporize and be forced into the steam zones, where the vacuum extraction can remove them. This 
heating may be followed by one or more additional steam injection phases for contaminant removal, and to keep permeable zones hot as ground water returns.

The overall geometry of a DUS system can take on either of the forms given in Figures 10 and 11. If a hexagonal pattern is used, steam, water, and electrical energy would be injected at the corners (wells A-F) while vacuum vapor extraction would be performed at the center (well Z). If a rectangular pattern is used, steam and/or water would be injected at the edges while electrical energy would be introduced in the center. Soil vapor extraction would be performed at the center line of wells. Figure 12 gives the major subsystem components needed to perform DUS at a given site.

Figure 12. DUS Major Subsystems

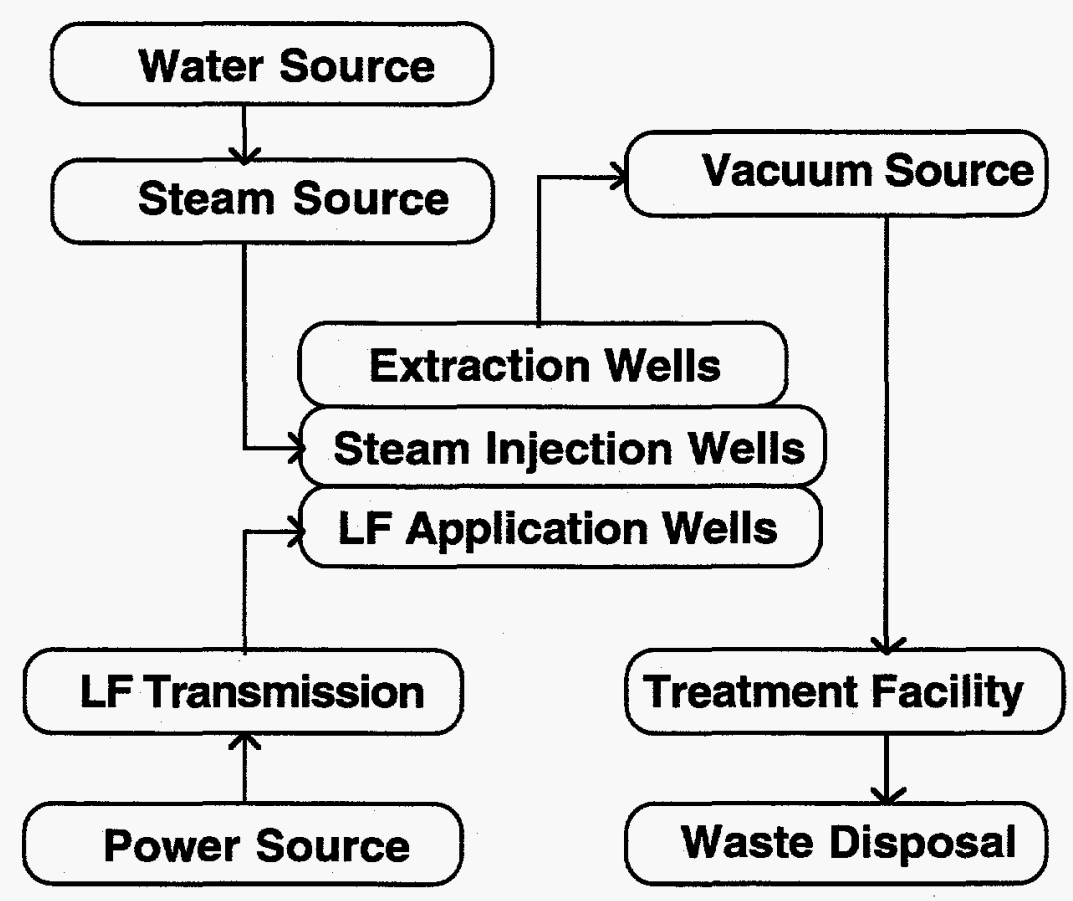

\subsection{Radio Frequency Heating (RF)}

$\mathrm{RF}$ heating is based on volumetric heating of the contaminated volume to an elevated temperature to result in volatilization of the contaminants. Heating the contaminated soil using the RF technology results in volatilization of the contaminants through a combination of evaporation, steam distillation, and steam assisted evaporation. The volatilized contaminants travel to the surface of the contaminated area or the nearest perforated electrode and are collected using a vapor extraction system. The contaminant vapors and steam are treated on-site.

The electrode array is formed by drilling multiple rows of electrodes in the soil volume which is to be heated. The electrodes are dropped into bore holes and electrically connected at the 
surface to the power source. A vapor barrier is placed on the surface to prevent fugitive emissions of gases and vapors formed upon heating of the soil. A description of the RF system is given in Figure 13. An important consideration in this technology is the amount of native water in the formation. If the moisture content is too high, the RF energy will be quenched by the water, limiting the top temperature that can be achieved to the boiling point of water for as long as it takes to remove sufficient water to allow dielectric heating of the soil contaminants.

This technology can be applied using either of the well geometries given in Figures 10 and 11. If the hexagonal array is used, then the RF energy might be applied to the center well while vacuum extraction may be applied to any of the wells. Similarly, the RF energy might be applied to the outer wells while vacuum extraction is applied to the center well. If the rectangular array is used, RF energy would be introduced into the formation from some of the centerline wells while vacuum extraction may be performed at any of the centerline wells. (The wells at the outside of the formation would be electrically grounded thus forming a means of guarding the formation outside the remediation site.)

Figure 13. RF Major Subsystems

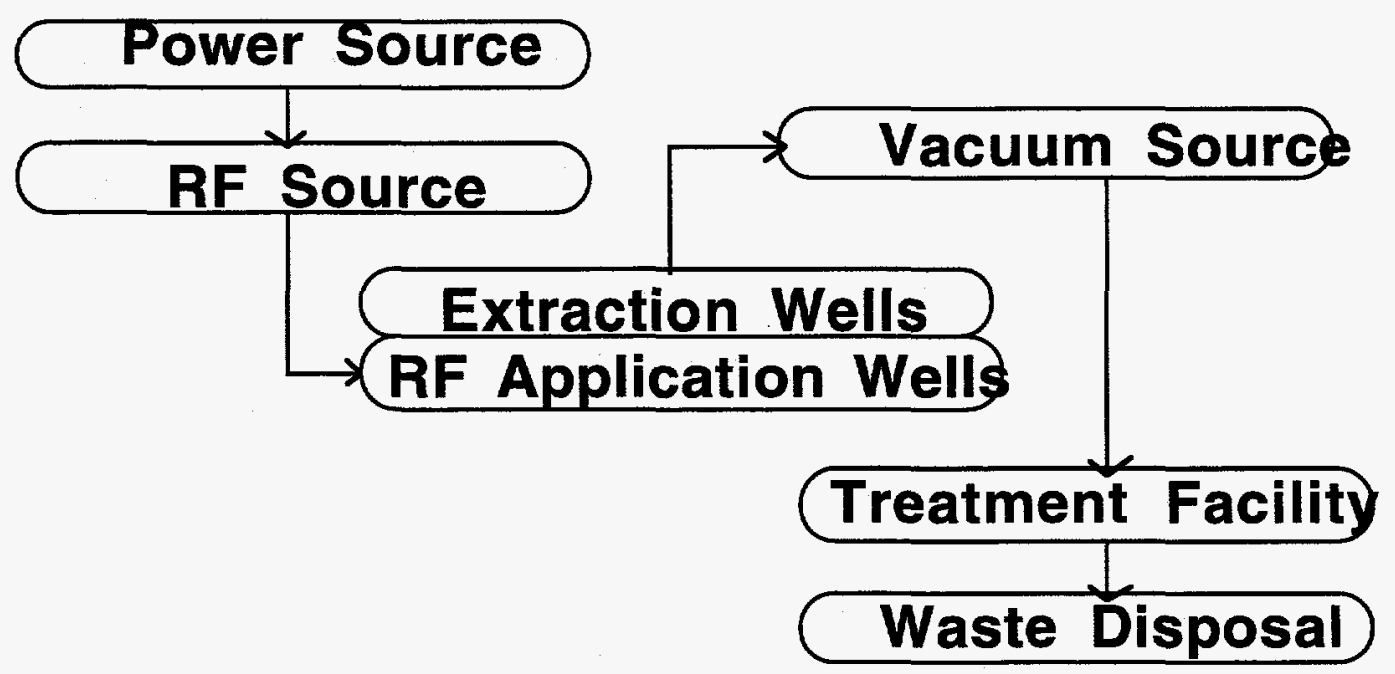

\subsection{Radio Frequency Heating with Dipole Antennae (RFD)}

For all intents and purposes, the only real difference between the RF system as described above and the RF Dipole system is in the type of applicator used to convey the RF energy to the soil. In the dipole system, a dipole antenna is used. This type of antenna allows the operator to target the RF energy in a particular direction. (A standard antenna would broadcast the RF energy in all directions equally, whereas a dipole antenna would broadcast the energy in the direction of a hemispherical lobe.) Due to this focusing, the dipole antenna has a limited radius of influence. 
The use of different frequencies can affect this radius, but overall the dipole antenna has a smaller radius of influence than the standard RF antenna. Therefore, more RF dipole wells would be needed to heat the same volume of soil. Beyond this, the two RF systems are identical in their effect. While it is tempting to say that using a dipole antenna would allow better heating of the contaminated volume through a selective heating of parts of the formation, in practice this has yet to be demonstrated. Both the RF and RFD techniques will be presented with no comment as to which might be better for a particular type of formation, thus allowing the reader to make that determination. The functional components of the RFD system are given in Figure 14. The application geometries presented above for the RF system also apply to the RFD system.

Figure 14. RFD Major Subsystems

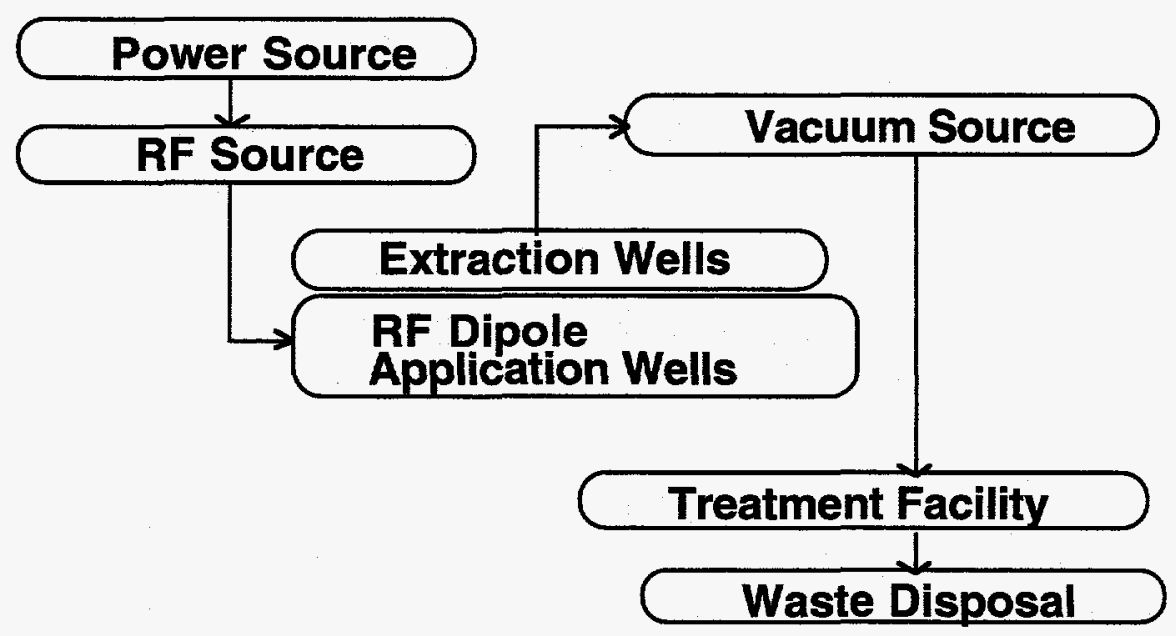

\subsection{Thermally Enhanced Vapor Extraction System (TEVES)}

The Thermally Enhanced Vapor Extraction System (TEVES) technology is the combined application of soil heating technology and vacuum vapor extraction soil remediation. This system combines the LF and RF systems described above. The design of this system is such that the LF component will be operated until the temperature of the formation is raised to the boiling point of water and the naturally occurring water in the formation is driven out of the formation to the point where the use of RF heating is possible and economically viable (and LF no longer functions due to the lack of water for soil conductivity). When this point is reached, the LF system will be discontinued and the RF system will be engaged. Once engaged, the RF system will drive the temperature of the formation to the desired level. Soil heating acts to improve the mass extraction rate of volatile, semivolatile and petroleum hydrocarbons from soils by increasing contaminant 
vapor pressures and inducing steam stripping action from existing water in unsaturated soils (Phelan and Dev, 1995). Figure 15 illustrates the major subsystem components needed to perform TEVES at a given site.

Figure 15. TEVES Major Subsystems

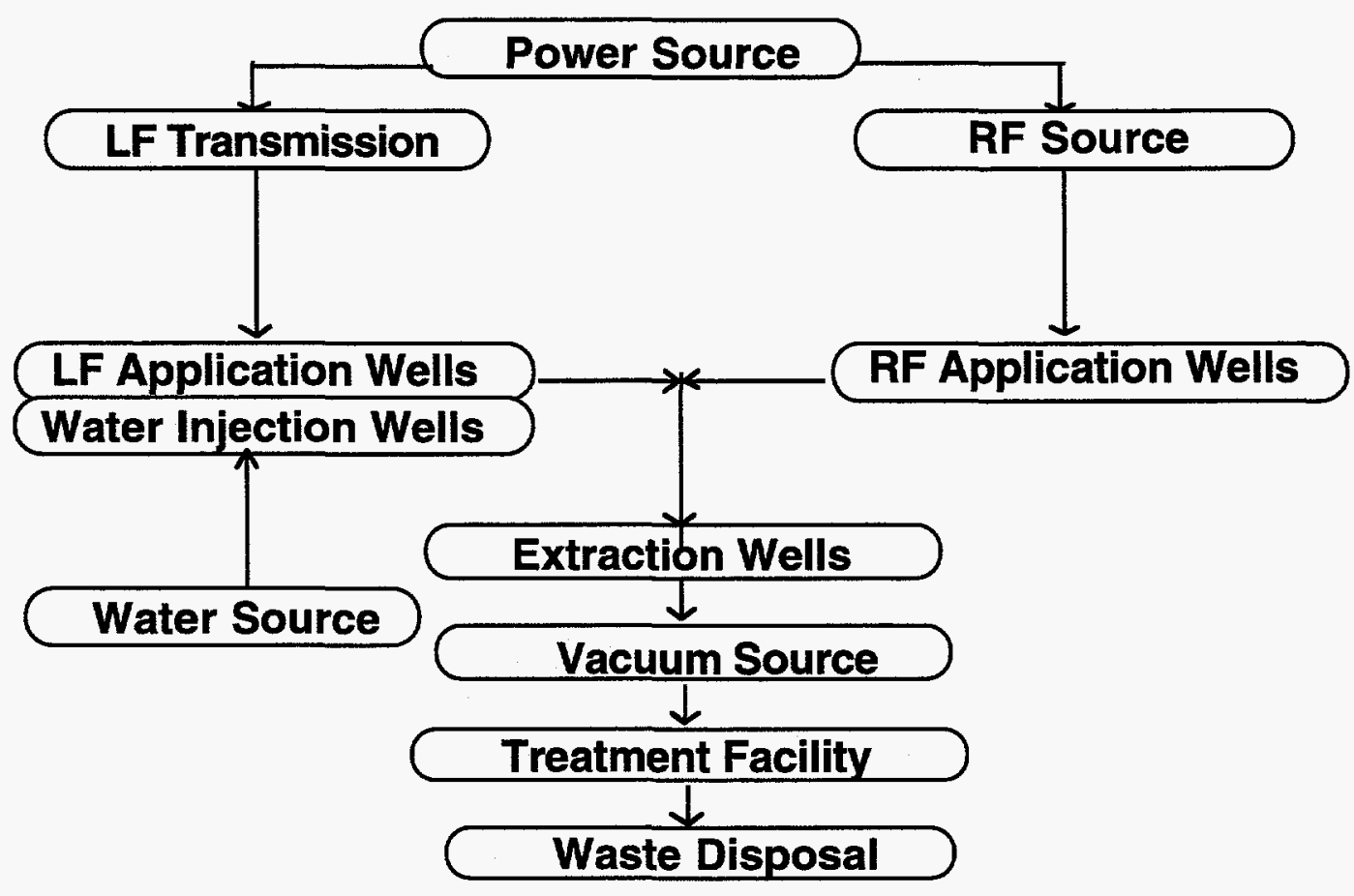

\subsection{Contaminant Plume and Well Placement Geometry}

Figures 10 and 11 give two possible geometries that any of the emerging technologies might employ. While other geometries are possible, it is believed that these two are the most likely to be used. The first type of geometry is called an hexagonal array. This type of geometry is best when used in cases where the contaminant plume is small enough to be fully encompassed by the array. Larger areas may be covered by using multiple repetitions of the hexagonal array, either concurrently or consecutively. The sides of the hexagonal array are limited to approximately 50 feet, with a maximum distance of approximately 100 feet between opposing vertices.

The second geometry is called a triplate array and gets its name from elementary electrical engineering. In this configuration, the (electrically) active wells are a subset of the wells in the center of the array. The wells in the outer edges are (electrically) grounded. Furthermore, the size of the array is limited to approximately 50 feet between the line of center wells and the line of edge wells on either side. While there is no theoretical limit to the length of the array, there is a practical 
limit in that the current necessary to power large arrays of this type will become staggeringly high if too many applicator electrodes are all to be activated simultaneously. The distance between applicator wells should be no more than approximately 50 feet. Note that the applicator wells (that is, wells where either LF energy or RF energy is coupled to the formation through an appropriate electrical network) should be a subset of the wells in the center line, but for cost effectiveness, need not be all of the wells in the center line.

In order to remediate areas where the plume is large with respect to the array type to be used, multiple arrays can be constructed, or, more likely, the plume can be divided and remediated in sections, reusing the components from the previous section. In these cases, the remediation effort must be carefully designed such that the entire plume is remediated while the contaminants are prevented from flowing out of the area to be remediated. This is of particular concern when large amounts of water or steam are to be introduced into the system (e.g., DUS).

For example, consider the geometry chosen in Figure 16. Suppose that the plume is to be remediated from left to right, using one hexagonal array at a time. If DUS is chosen as the technology to be used, then care must be made in choosing the wells to inject steam. (Similar care must be exercised when using a triplate array.) In this case, by always injecting steam from only the two left-most wells and the top and bottom well, and drawing the extraction from the center well, the plume will be driven towards the right and towards the centerline. When the far right side is reached, injecting steam into all of the outside edge wells will be required to remediate the entire plume. Generally speaking, steam or water should be injected from as close to the outer perimeter of the plume as possible, and in such a way that the shape of the contaminant plume is caused to collapse on itself.

Figure 16. Multiple Hexagonal Array Example

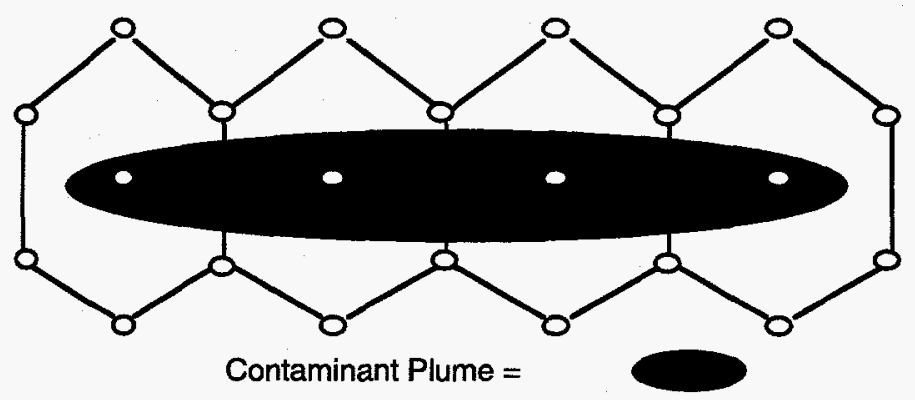

\subsection{Choice of Baseline Technology}

Of the three conventional means of performing soil decontamination (E\&T, P\&T, SVE), only one will be used as the baseline technology for each scenario. First, while E\&T can remove all of the contamination in a given volume, it is considered to be too costly except for that small 
percentage of sites where the contamination is confined to a volume that remains close to the surface. Therefore, E\&T will be the baseline technology for Scenario 1, Shallow Vadose Contamination. SVE will be used as the baseline technology for Scenarios 2 and 3, Deep Vadose Zone Contamination. As for P\&T, while it is an inexpensive system to install, the treatment times can be very long. P\&T also carries with it the resignation that the contamination must reach the water table before it even begins to be remediated. One goal, for any technology, should be to protect the water table from contamination as much as possible. Hence, P\&T is considered inappropriate in all cases where the contamination has not yet reached the water table. A combination of P\&T and SVE will be used as the baseline for Scenario 4, Deep Vadose Groundwater Contamination. SVE will also be the baseline technology for Scenario 5, Restricted Access Contamination.

\subsection{Component Descriptions}

Table 3 lists all of the various components that will be used in the discussions in sections to follow. It contains the name of the component and indicates which technologies will use that component. Any components that are common to all of the technologies will be described (generally and economically) once and then not discussed further as these components do not represent a cost difference between the technologies. Additionally, for each component a cost summary breakdown is presented. The reader should note that these components will be designed once and used by all of the relevant technologies. This may result in component designs that are, in some cases, more robust than may be strictly necessary for a given technology.

Table 3. Components and Technologies

\begin{tabular}{|l|c|c|c|c|c|c|c|c|c|}
\hline Component & E\&T & TEVES & SVE & LF & DUS & $\begin{array}{c}\text { P\&T } \\
\text { SVE }\end{array}$ & RF & RFD & $\begin{array}{c}\text { Restricted } \\
\text { Access } \\
\text { SVE }\end{array}$ \\
\hline Vacuum System & & $\mathrm{X}$ & $\mathrm{X}$ & $\mathrm{X}$ & $\mathrm{X}$ & $\mathrm{X}$ & $\mathrm{X}$ & $\mathrm{X}$ & $\mathrm{X}$ \\
\hline Extraction Wells & & $\mathrm{X}$ & $\mathrm{X}$ & $\mathrm{X}$ & $\mathrm{X}$ & $\mathrm{X}$ & $\mathrm{X}$ & $\mathrm{X}$ & $\mathrm{X}$ \\
\hline Treatment System & $\mathrm{X}$ & $\mathrm{X}$ & $\mathrm{X}$ & $\mathrm{X}$ & $\mathrm{X}$ & $\mathrm{X}$ & $\mathrm{X}$ & $\mathrm{X}$ & $\mathrm{X}$ \\
\hline Water Source & & $\mathrm{X}$ & & $\mathrm{X}$ & $\mathrm{X}$ & & & & \\
\hline LF Application Wells & & $\mathrm{X}$ & & $\mathrm{X}$ & $\mathrm{X}$ & & & & \\
\hline Power Source & $\mathrm{X}$ & $\mathrm{X}$ & & $\mathrm{X}$ & $\mathrm{X}$ & & $\mathrm{X}$ & $\mathrm{X}$ & \\
\hline Steam Source & & & & & $\mathrm{X}$ & & & & \\
\hline Steam Injection Wells & & & & & $\mathrm{X}$ & & & & \\
\hline RF Source & & $\mathrm{X}$ & & & & & $\mathrm{X}$ & $\mathrm{X}$ & \\
\hline RF Application Wells & & $\mathrm{X}$ & & & & & $\mathrm{X}$ & & \\
\hline $\begin{array}{l}\text { RF Dipole Application } \\
\text { Wells }\end{array}$ & & & & & & & $\mathrm{X}$ & \\
\hline
\end{tabular}




\subsubsection{Vacuum System}

A vacuum system is used by all of the technologies that involve vapor extraction. Its function is to create an area of diminished air (and vapor) pressure in the formation in the vicinity of the extraction well(s) and to remove air, vapor, and steam (if any) from the formation. Additionally, the vacuum source component will be used to convey the removed gasses and vapors to the treatment component.

The vacuum system is set up for a flow rate of 100 cubic feet per minute (cfm) from each extraction well. A 3.0 horsepower blower is considered adequate to pull out 60 inches of water vacuum at the rate of $100 \mathrm{cfm}$. The vapor abatement system will comprise a thermal oxidizer with a catalytic module, trailer option, telemetry option, silence package, vacuum upgrade, and pump and level switches on the water vapor separator. The total cost of the vacuum system, based on one extraction well, is approximately $\$ 175,000$.

\subsubsection{Extraction Wells}

At least one extraction well is also required by all of the technologies utilizing a vacuum system. This well is connected directly to the vacuum source and, hence, to the treatment facility. The purpose of the extraction well is to convey air, vapor and steam (if any) from the contaminant plume to the vacuum source.

Each extraction well will be a 10 -inch diameter with a 4-inch diameter stainless steel casing in the uppermost section of the well, and 4-inch diameter stainless steel screen extended for the remainder of the well. The annular space between the casing and boring is filled with grout around the casing and sand around the screen (see Figures 17 and 18). The cost of each extraction well is approximately $\$ 11,500$ for the depths involved in our specific scenarios. Of course well drilling costs are highly variable depending on local conditions, so our costs could be misleading for other geologies or remediation requirements. 
Figure 17. Well Diagrams for Baseline SVE System
Figure 18. Well Diagrams for Baseline SVE System in TEVES

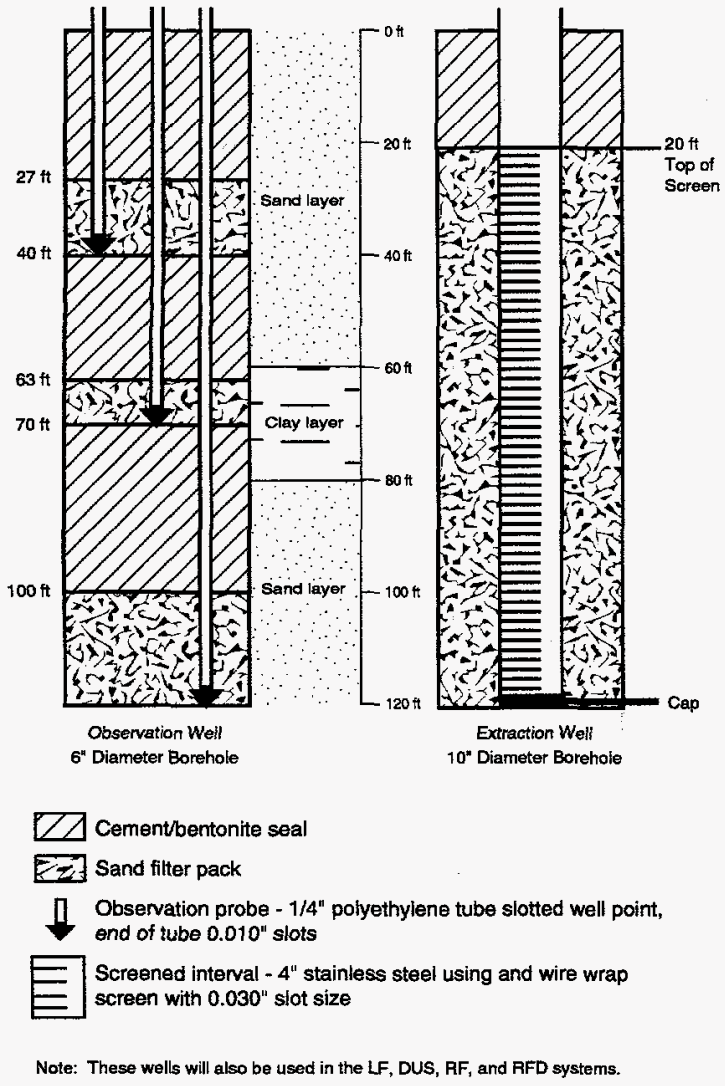

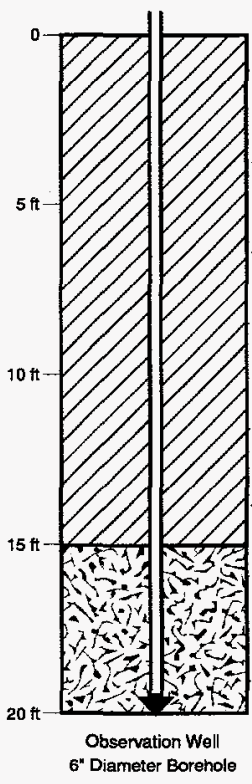

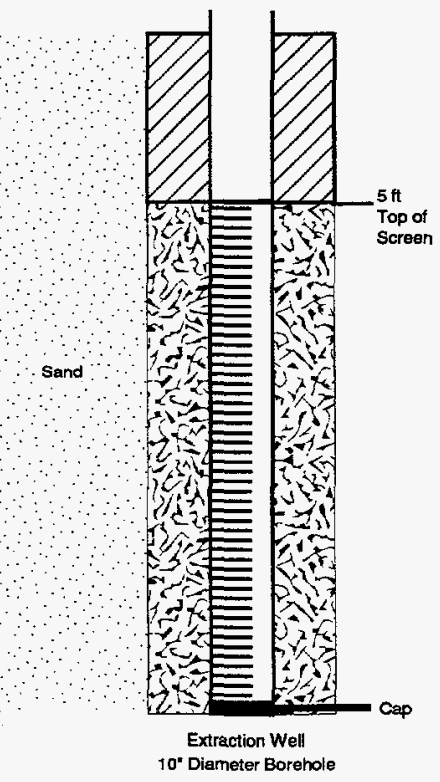

\subsubsection{Treatment System}

The treatment system in the vapor extraction applications is responsible for accepting the gasses and vapors presented to it by the extraction well(s) and to destroy or otherwise dispose of them. The treatment system consists of a water treatment skid, electrical connections, and equipment shipping. The water treatment skid unit will be installed to handle a flow rate of less than 10 gallons per minute $(\mathrm{gpm})$. It will include a vapor water separator, transfer pumps, carbon units, oil-water separator, and all of the appropriate sensors, switches, plumbing, electrical controls, valves, and other equipment. The treatment of groundwater is also dependent upon the climatic conditions, i.e., dry, arid or temperate climates do not require a separate groundwater treatment system for treating the moisture content of the process stream, but may become imperative in places with considerable humidity. If groundwater is not being treated and discharged, then a groundwater discharge permit is not required. The cost of the water treatment system is approximately $\$ 51,000$. 
The treatment system for the DUS technology is different because of the increased volume of water to be treated. The water treatment system skid unit will be installed to handle a flow rate of about $120 \mathrm{gpm}$. Steam extracted will be condensed using an air-cooled condenser. The steam is drawn using a blending blower. The air-cooled condenser is typically a heat exchanger. The condensate is directed to an air/water separator. The liquid portion is sent to a water treatment system whose primary component is a carbon adsorption unit. The water is then reused in the boiler. The vapors from the separator are sent to the vapor abatement system consisting of a thermal oxidation unit.

The treatment system for the E\&T method is a thermal desorption system. This system consists of the wheel loader, feed and discharge hoppers, elevating conveyor, screen unit, filter press, off gas systems, and the rental of a 10,000 lb/hour firing unit.

The treatment system for the SVE/P\&T method is a water treatment skid. The water treatment skid unit will be installed to handle a flow rate of less than $60 \mathrm{gpm}$. It will include a vapor water separator, transfer pumps, carbon sensors, switches, plumbing, electrical controls, valves and other equipment. The treatment of groundwater is also dependent upon the climatic conditions, i.e., dry, arid or temperate climates do not require a separate groundwater treatment system for treating the moisture content of the process stream, but a separate system may become imperative in places with considerable humidity. The cost of the water treatment skid and associated equipment is approximately $\$ 54,000$.

\subsubsection{Water Source}

A water source is required by LF and DUS, though the amounts of water used are very different. LF requires water to be present in the formation at concentrations sufficient for conducting electrical energy across the formation. Since the purpose of the LF electrical energy is to increase the formation temperature to the boiling point of water, the water that was originally in the formation will be driven off by the air sweep that is formed in the formation by the vacuum component. Thus, if LF heating is to be used after the water level has been reduced, additional water will need to be injected into the formation. With DUS, a much greater amount of water is necessary due to the use of the steam as both a means of heating the formation and as a sweeping agent in the formation. The steam will be recycled and stored in tanks for reuse. The water is provided by a hookup to the municipal water system. The cost of this hookup is approximately $\$ 24,400$. For the DUS system, the rental of three water storage tanks are also included at a total annual cost of $\$ 26,400$. 


\subsubsection{LF Application Wells}

In the LF system, a means of supplying the electrical power to the LF applicators must be provided. While the three phase system uses input directly from a typical AC power source, the 6 phase system must use each of the original 3 phases, shifting each by an appropriate phase angle, and assuring that each of the phases is able to supply the correct voltage and current. Schematically, this process is shown in Figures 19, 20 and 21.

Figure 19. 6 Phase Conversion Network

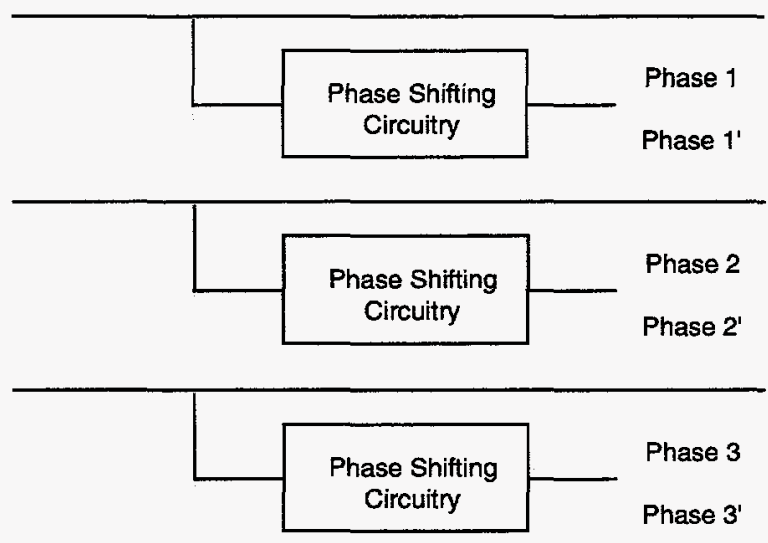

Figure 20. 3 Phase AC Signals

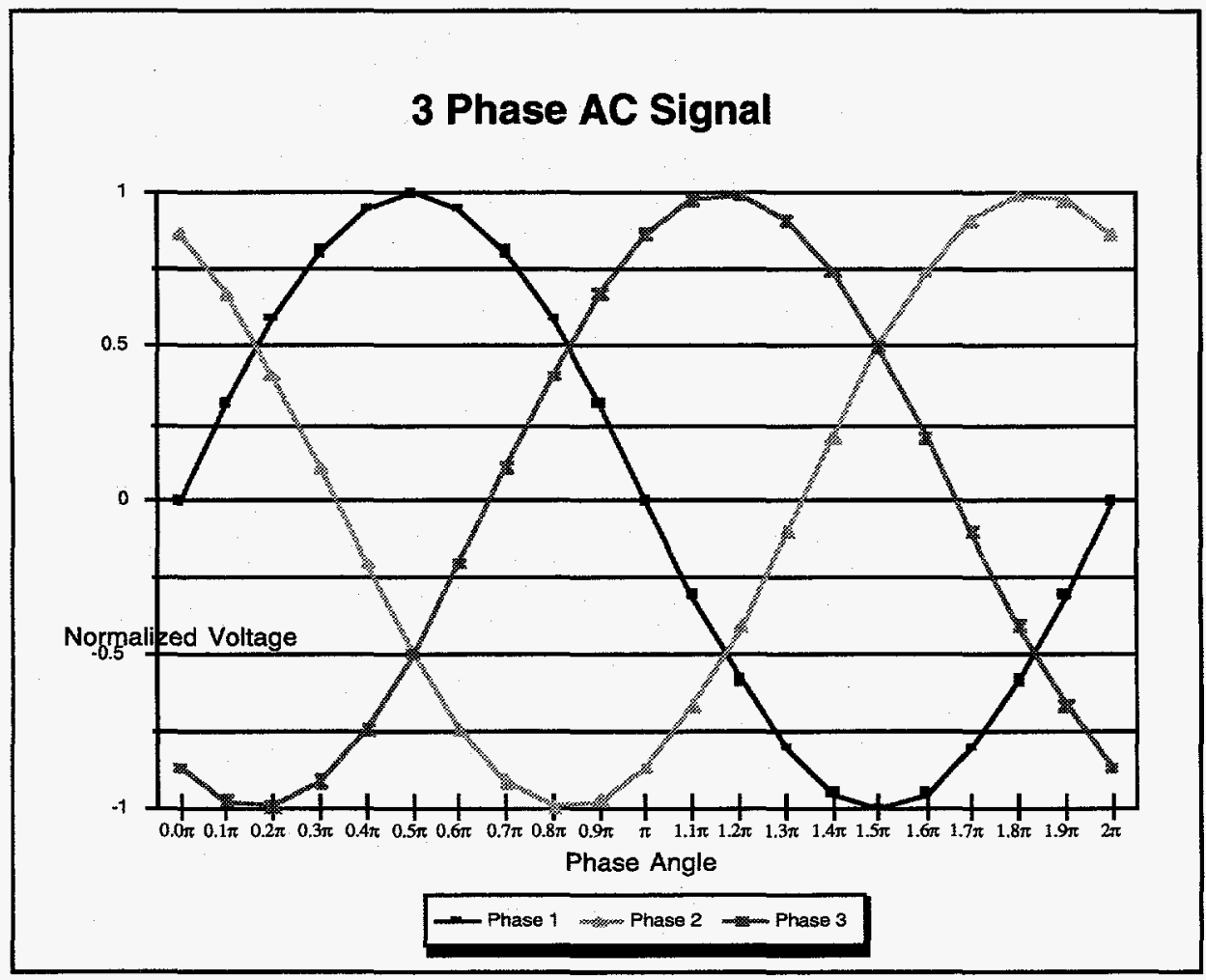




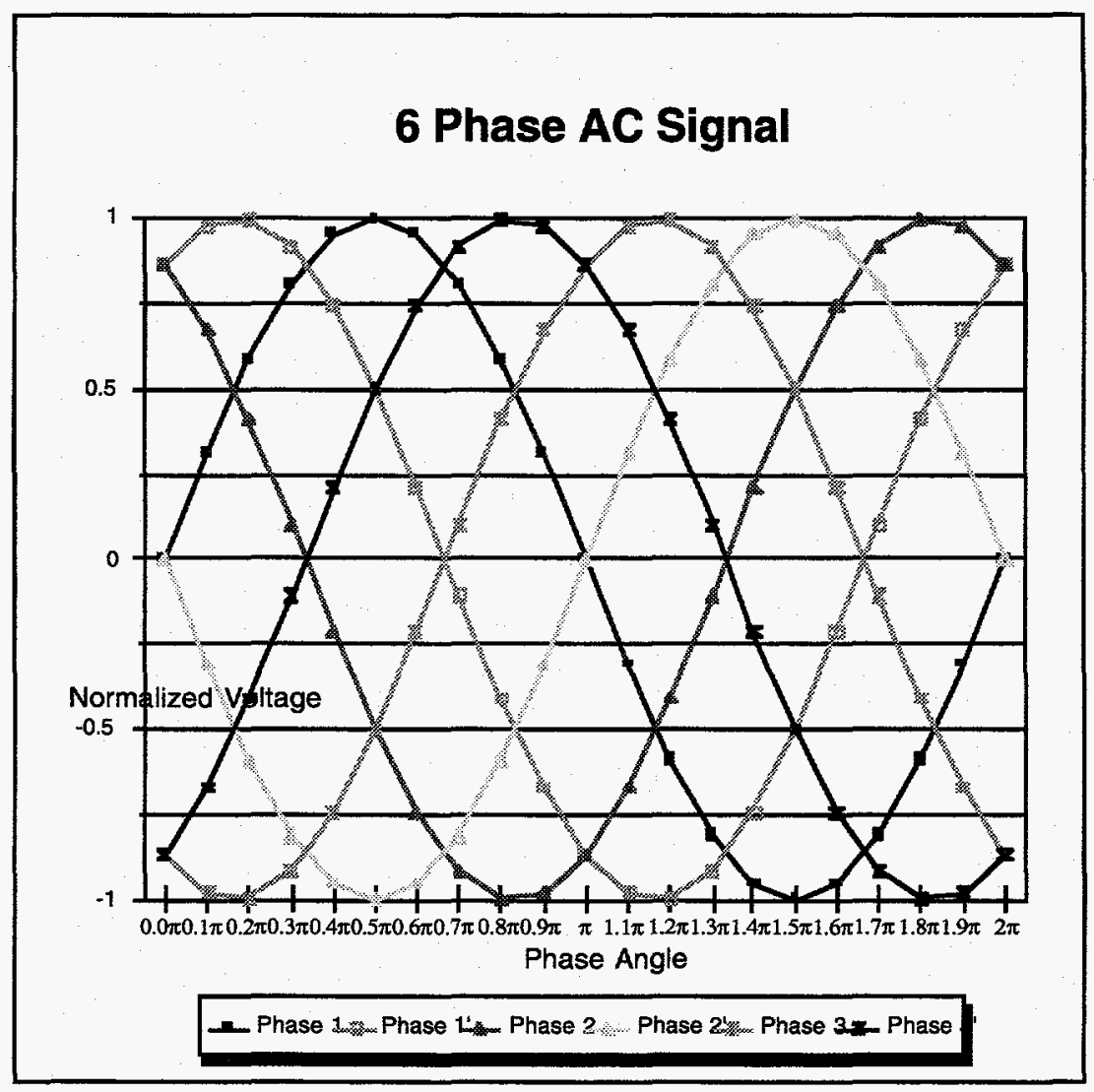

Once the 6 phases are appropriately separated (the phase angle difference between a signal and its shifted result should be either + or - (/3) and their currents and voltages correctly set, the phases are applied in pairs across the formation. For example, (1 might be applied at location $\mathrm{A}$ (see Figure 10) with its complement, ( 2 applied at location D. Similarly, ( 2 at C, ( 3 at F, and ( 3 at $E$ with (1' at B. A pattern of this type would provide for a maximum potential difference across each pair of electrodes, thus providing for a more uniform heating of the formation.

With the LF system, a means of conveying the electrical energy to the formation must be provided. This means is usually through the use of LF applicator wells just outside the periphery of the contaminant plume. The casing of the wells will be used as the LF application electrodes.

The LF application wells will be a 14-inch diameter boring with 4-inch diameter stainless steel pipes and screen serving as LF application electrodes (see Figures 22 and 23). When employing an LF system, the water that is needed to maintain the electrical conductivity of the formation must be introduced into the formation in some manner. The LF application wells will be used to convey the water to the formation. 
Figure 22. Well Diagram for Low Frequency (LF) Systems

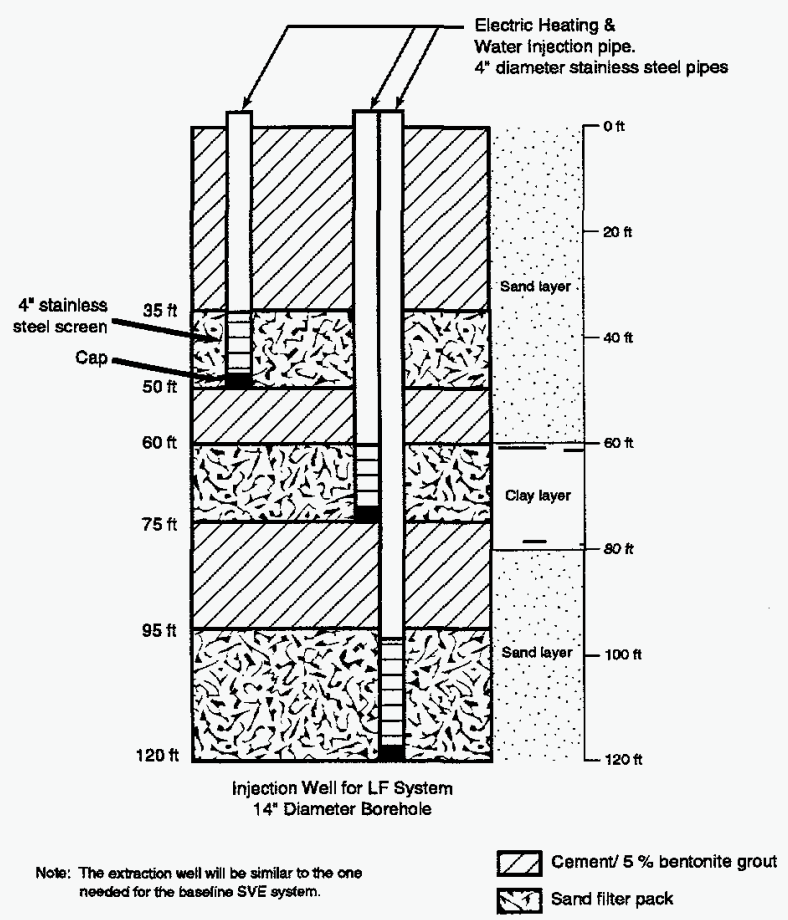

Figure 23. Well Diagram for Low Frequency (LF) Injection Wells in TEVES

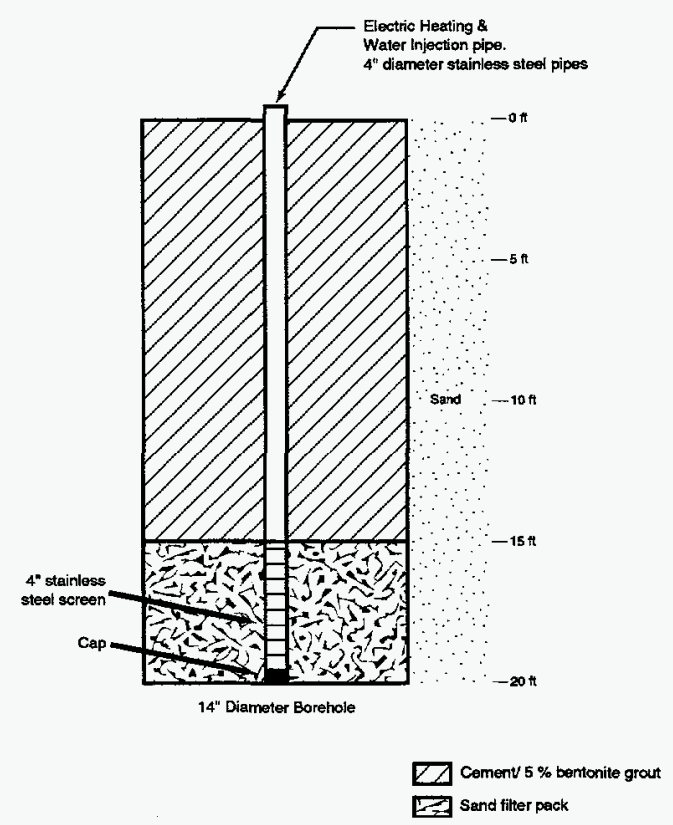

\subsubsection{Power Source}

Electrical power must be supplied to the systems. This can be in the form of a portable generator or AC power taken directly from commercial power lines.

For the LF and DUS systems, the power source used is overhead power lines supplying power to a step-down transformer. A control panel is provided for electrical distribution purposes. The six-phase LF power source also includes a six-phase transformer. For the RF and RFD systems, power is provided by RF delivery systems and AC power drops as described under RF Source.

\subsubsection{Steam Source}

In the DUS system, a source of steam and a means of conveying that steam to the formation must be provided. The steam source to the injection wells is a trailer mounted steam boiler. The boiler uses some type of gaseous fuel. Steam hoses are used to supply steam to the injection wells at the six corners of the hexagon. Assuming the boiler is mounted at a distance of 5 $\mathrm{ft}$ from one of the injection wells, it would require a total of $600 \mathrm{ft}$ of hose for the steam supply. The cost of the steam source is approximately $\$ 84,000$. 


\subsubsection{Steam Injection Wells}

The final component for the DUS system is the steam injection wells. These wells will be the means that is used to convey the steam to the formation from the surface. The wells will consist of steel pipes placed in six, 14-in diameter boreholes drilled to a depth of 120-ft. A 4-in stainless steel pipe will be used to supply steam to the formation. A 2-in stainless steel pipe will be used to provide electricity to the clay formation, as shown in Figure 24. The average cost of each steam injection well is approximately $\$ 15,250$.

\section{Figure 24. Well Diagram for Dynamic Underground Stripping (DUS) System}

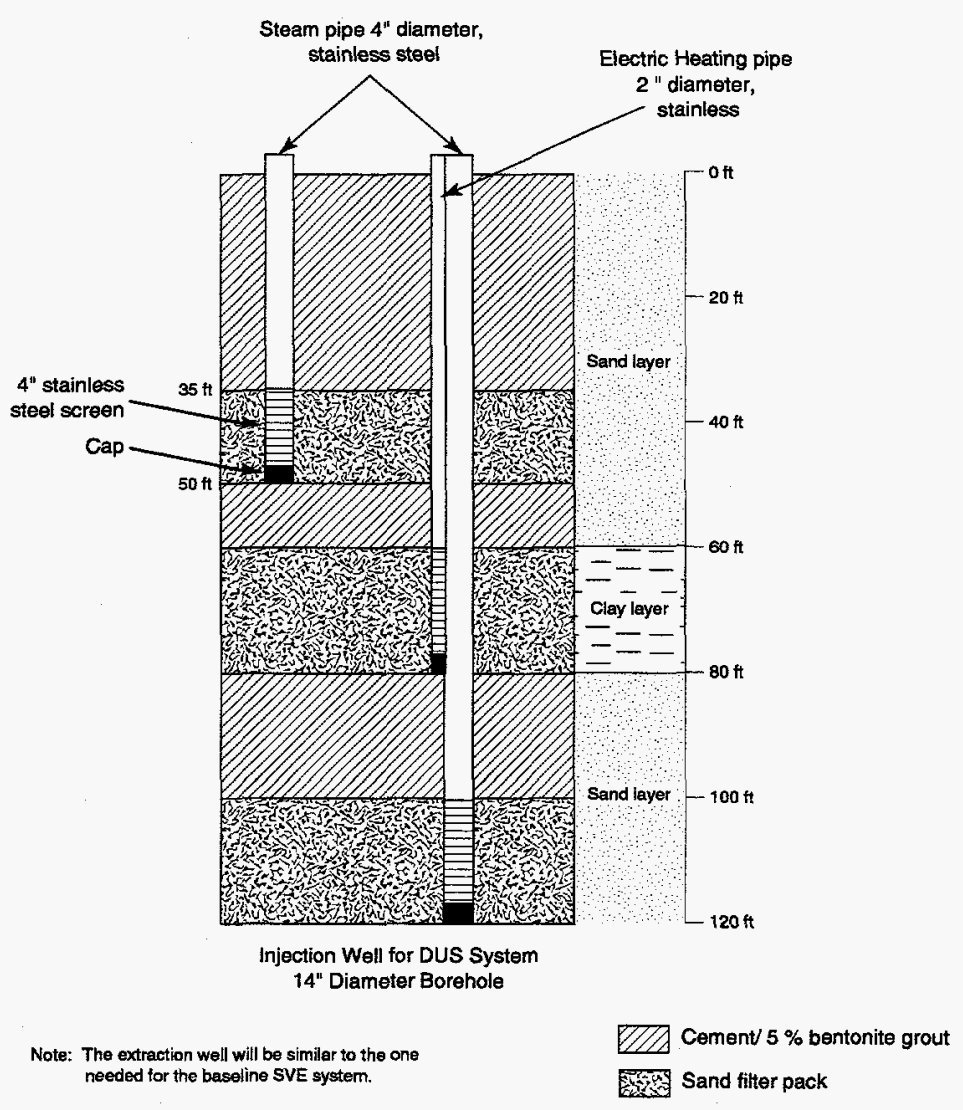

\subsubsection{RF Source}

For the RF and RFD systems, a means of converting electrical line power to RF power is required. The task of the RF source component will be to convert line frequency power to RF power and to convey that power to the RF (or RFD) applicators. The means of conveying the RF power to the applicator wells will be through the use of high power coaxial cables.

The RF and RFD power is provided by RF delivery systems and AC power drops as described above. The delivery systems include all of the equipment necessary to get the RF energy to the application wells, including the RF antennas. The RF antennas will be placed into the RF 
application wells, and raised and lowered to provide energy to the entire formation. The cost of the RF delivery systems is $\$ 200,000$ each, with the AC power drops being $\$ 20,000$ each. The cost of the RFD antennae is included in the cost of the RFD application wells.

\subsubsection{RF Application Wells}

The RF application wells are used to convey the RF power supplied by the RF source into the RF antennae and, thus, to the formation. The RF application wells will be 6-in diameter borings with 4-in diameter fiberglass reinforced polyester (FRP) pipe (see Figures 25 and 26). The cost of each well is approximately $\$ 3,600$. The cost of the RF antenna is included in the cost of the RF delivery system.

Figure 25. Well Diagram for Radio Frequency Application Well

Figure 26. Well Diagram for Radio Frequency Application Well in TEVES

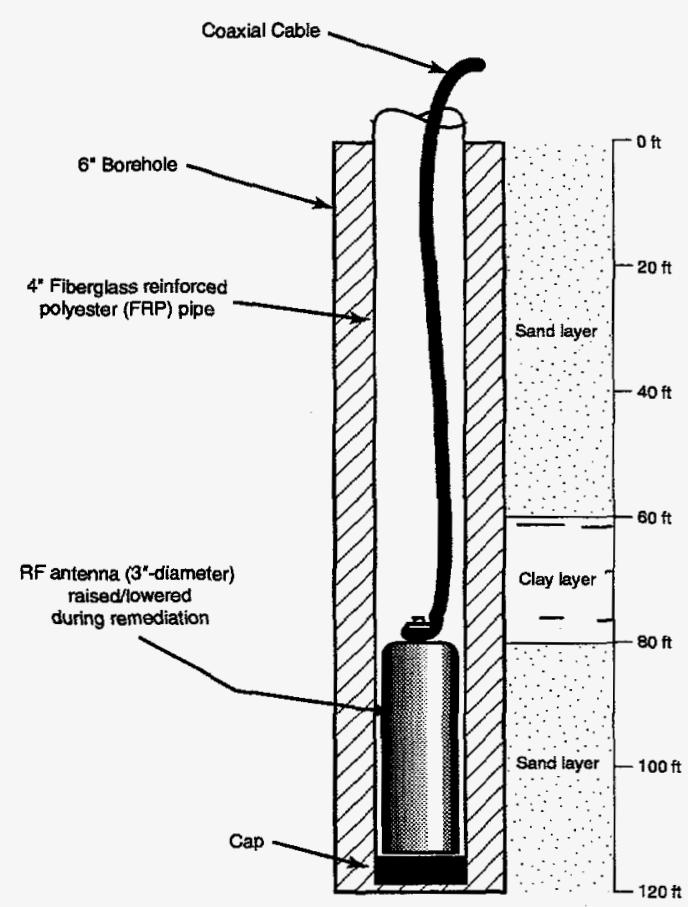

Cement/ $5 \%$ bentonite grout

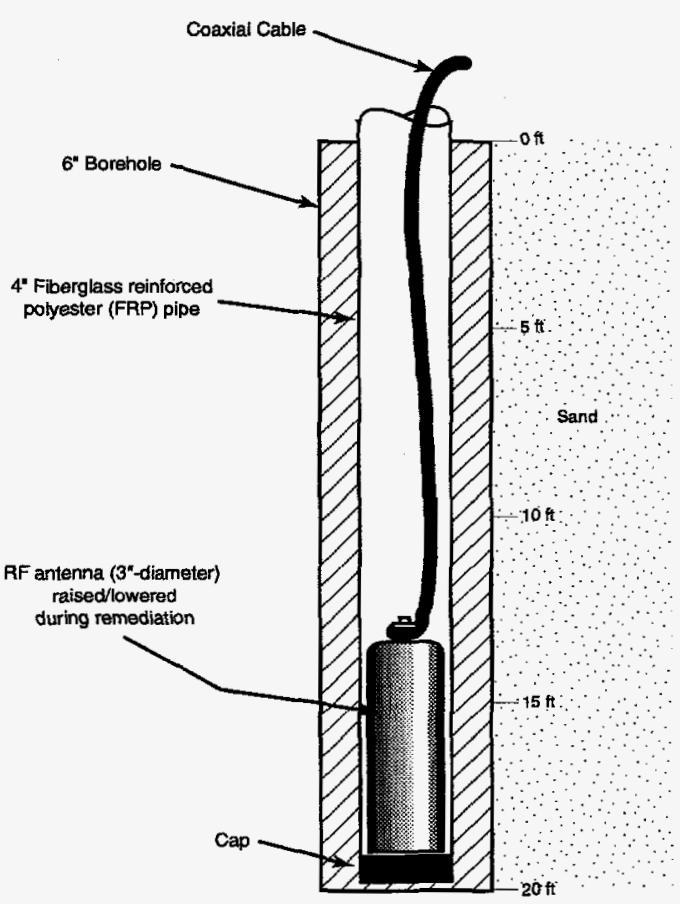

DCement/ $5 \%$ bentonite grout

\subsubsection{RF Dipole Application Wells}

The RF dipole application wells are the RFD equivalent of the RF application wells component described above. The RFD application wells will be 6-in diameter borings with 4-in 
diameter FRP. The RFD technology is discussed in the restricted access scenario. The well will be bored at an angle with a length of $60 \mathrm{ft}$ to a depth of about $20 \mathrm{ft}$ (see Figure 27). The dipole antennae have a radius of influence of $8 \mathrm{ft}$ and can be raised and lowered and rotated to focus the energy in the area of interest. Each well will cost approximately $\$ 1,900$ with each RFD antenna costing $\$ 20,000$.

\section{Figure 27. Well Diagram for Radio Frequency Dipole Angled Application Well}

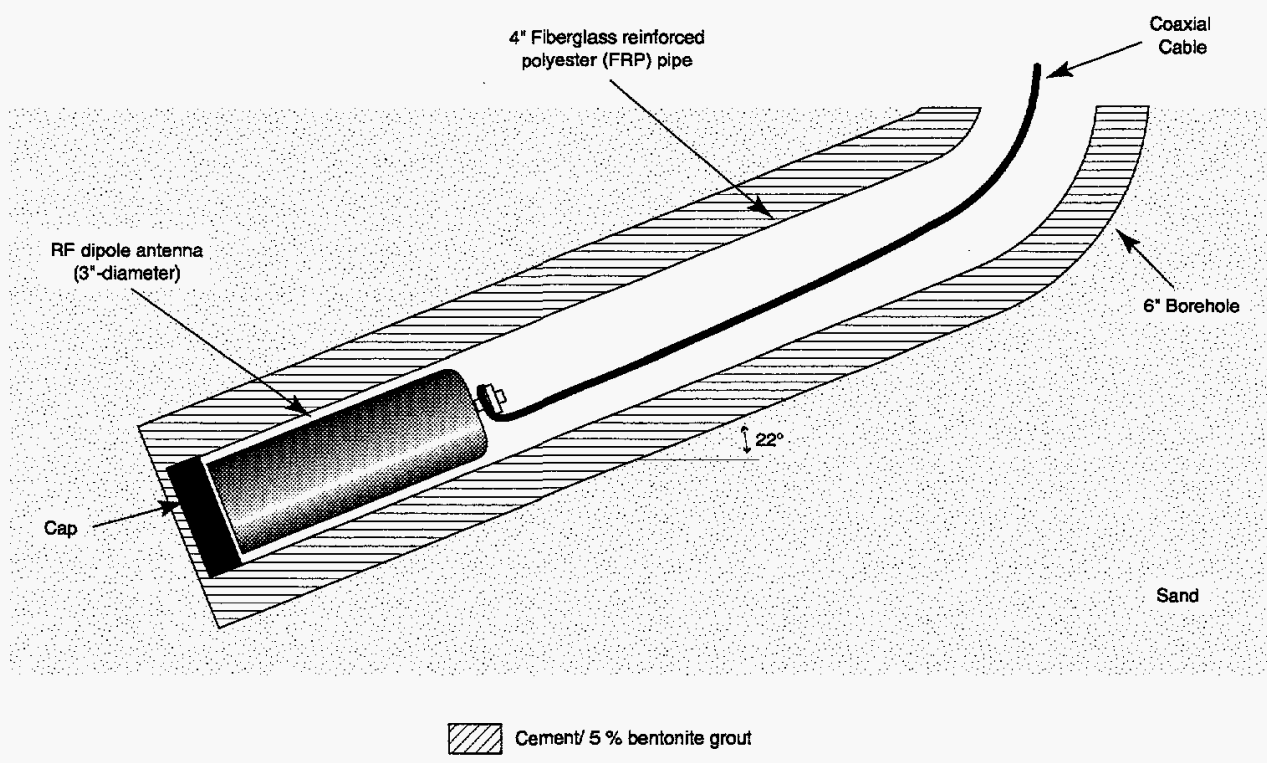

\subsection{Monitoring the Remediation Process}

In addition to the above components, it is necessary to provide a separate component that is capable of monitoring the remediation process. This might be as simple as a set of tools lowered into existing wells, or as complicated as creating a separate set of wells for the single purpose of such monitoring. Exactly what will be required at a given site will depend heavily on the site itself, and on the regulations in force that pertain to a given site. Should monitoring be required, at a minimum the following information should be gathered:

air, steam, and contaminant vapor mobility;

contaminant concentrations;

formation temperature field measurements.

The purpose of monitoring includes the determination of when the remediation process is completed, post-remediation monitoring of the contamination level in the formation, and to insure the environmental safety of the area surrounding the contaminant plume (that is, to help to insure that the contaminants are indeed moving towards the extraction well(s) in the interior of the contaminant plume rather than towards the outside of the plume). 
There are several types of monitoring that are available. Two techniques used by DUS investigators at Lawrence Livermore National Laboratory seem to be very appropriate for not only DUS, but also for the other emerging technologies. These are thermal monitoring and electrical resistance tomography (ERT).

Thermal monitoring provides information about the temperature field in the formation. This will be a key measurement for the TEVES hybrid system being designed and tested by researchers at Sandia National Laboratories. Electrical resistance tomography is used to generate three dimensional maps of the electric field, resistance, and temperature of the formation. Both techniques yield information as to the movement of steam at and between wells.

Finally, the oil industry has developed myriad techniques for well logging using a wide range of sensor types that are deployed down existing and specially constructed wells. Some research, which is beyond the scope of this report, should be performed to determine which, if any, of these techniques should be employed at a given site.

For the purposes of this study, observation wells will be used to monitor the remediation process. During site characterization, boring wells will be drilled to identify the lateral extent of the contamination. The borings will be sampled at five-foot intervals for the subsurface lithology and for analysis of volatile organic compounds (VOCs), semi-volatile compounds (SVOCs), and total petroleum hydrocarbons (TPH) such as gas and diesel. Various EPA methods will be used in order to quantify the extent of contamination, whereas geotechnical analyses will include determination of porosity, moisture content, dry bulk density (DBD), and specific gravity (SG). Some of the borings will then be made into observation wells with soil vapor extraction observation probes placed in each. The remaining borings, if any, will be filled with grout. The cost of the site characterization, including analytical costs and the cost of installing the observation wells, will be approximately $\$ 26,000$.

\section{Cost Comparisons}

The cost analyses presented in this report will use various factors as independent variables. This will provide a study that is generally useful. Although the contaminants in the plume are assumed to be both VOCs and SVOCs (see scenario descriptions for specific examples), we do not base the cost data on specific contaminants. The amount of time (and, therefore, the costs) necessary to raise a contaminant plume to a desired temperature will depend on the lithology of a given site and the power source. Subsequent to reaching the desired internal temperature, power can be reduced to hold at that temperature level. Geologic considerations will include the relative permeability and porosity of the site, the natural water content, and other physical factors that affect the capacity of the plume to absorb energy in the form of heat and/or electricity. 
The temperature that the formation is to be raised to is dependent on the contaminants present in the plume. One general rule of thumb from the literature is that the formation should be raised to a temperature at least one half of the volatilization point of the contaminant. At this temperature the partial pressure of the contaminant vapors reaches a point sufficient for removal under vacuum conditions. This temperature is not sufficient for contaminant destruction. For VOC contaminants, a final temperature of about $100 \mathrm{C}$ may be suitable, while for SVOC contaminants, temperatures of $250 \mathrm{C}$ or higher may be necessary. The temperature required at a specific site will necessarily be determined by laboratory tests that are specific to that site.

The amount of time that this temperature is to be maintained (and the costs necessary to maintain this temperature) is determined by the initial types and concentration of particular contaminants at a site, the relative volumes of high permeability and low permeability zones, and other physical factors affecting the ability of the site to maintain a given temperature. For example, a given site might contain an initial concentration of $100 \mathrm{ppm}$ of a given contaminant. Depending on the contaminant, a final concentration of $1 \mathrm{ppm}$ might be required or $1 \mathrm{ppb}$ might be required for a different (more toxic) contaminant. The more restrictive the final contamination level, the longer the elevated temperature must be maintained. In our cost calculations, we have taken a nominal heating campaign length of time to be 6 months. Actual demonstration results indicate that the thermal heating techniques under study can typically be expected to achieve their cleanup goals in less than six months. The cost savings of these thermal technologies arise from their short duration compared to the multi-year, non-thermally accelerated baselines. The necessary properties to determine the economic viability of a given technology at a specific site must be inferred by the reader based on site specific conditions.

Time value of money will have a small but measurable effect on the cost comparisons presented in this report. The thermal technologies represent very short (less than one year) project times, so discounting is of negligible importance except in the amortization of some long-life, reusable capital equipment. Much of what would normally be considered long-lived capital (wells, casing, slurry, mobilization, characterization, etc.) is sunk in the ground -- uniquely useful only to a specific project -- and so it is not appropriate to amortize given the short (6 month) campaigns typical of the thermal technologies. A present value computation will be used to take into account the effect of the longer, standard SVE technology baselines, and the reusable equipment of the thermal campaigns. Basically speaking, a present value computation is designed to compute the value of an investment or expense to be made in the future in terms of constant dollar values today. It is determined by discounting the costs from an activity back to the present time. We ignore any effects of inflation in our costs and use a real discount rate as determined by the Office of Management and Budget (OMB Circular No. A-94, February 1996). The literature suggests that the most important performance factor with regards to any of these technologies is the number of 
each type of well that must be drilled. For specific well configurations as they relate to the various scenarios, refer to Figures 28 through 32.

\section{Figure 28. Contaminant Plume and TEVES Configuration}

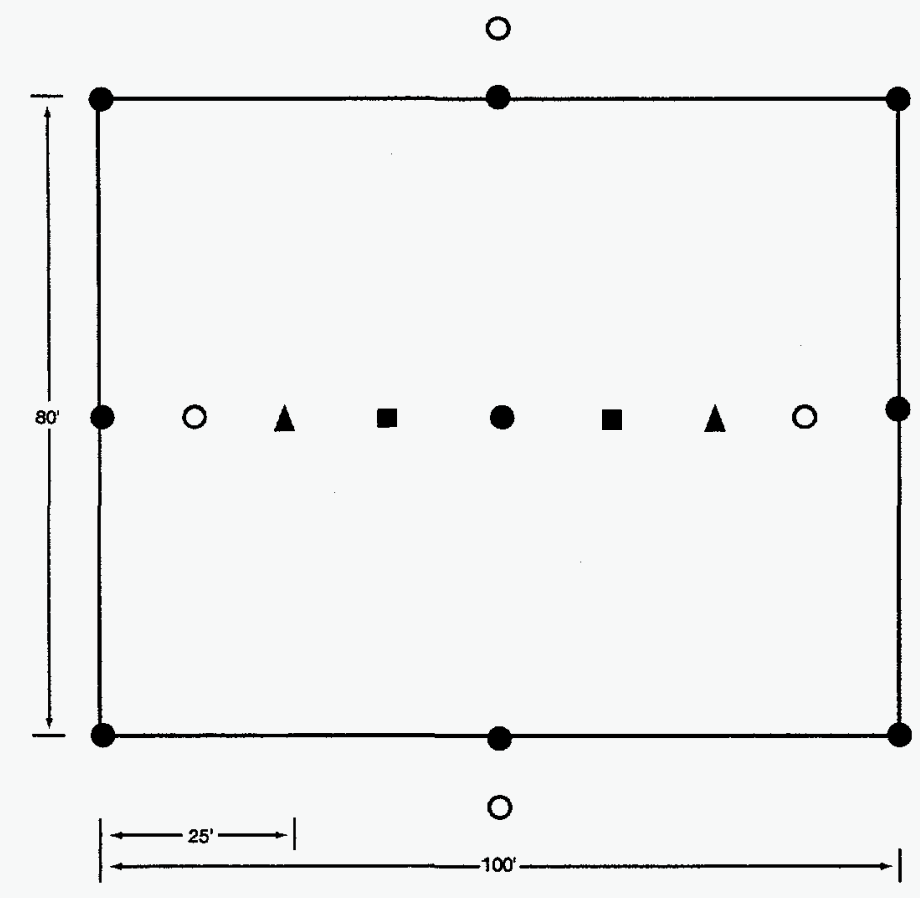

Plume Surface Area $=\mathbf{8 , 0 0 0}$ sq. $\mathrm{ft}$.

Legend

ARF Application Wells
LF Application Wells
Extraction Wells
Boreholes Drilled and Sampled for Site Characterization
and then made into Observation Wells


Figure 29. Contaminant Plume and SVE Well Configuration

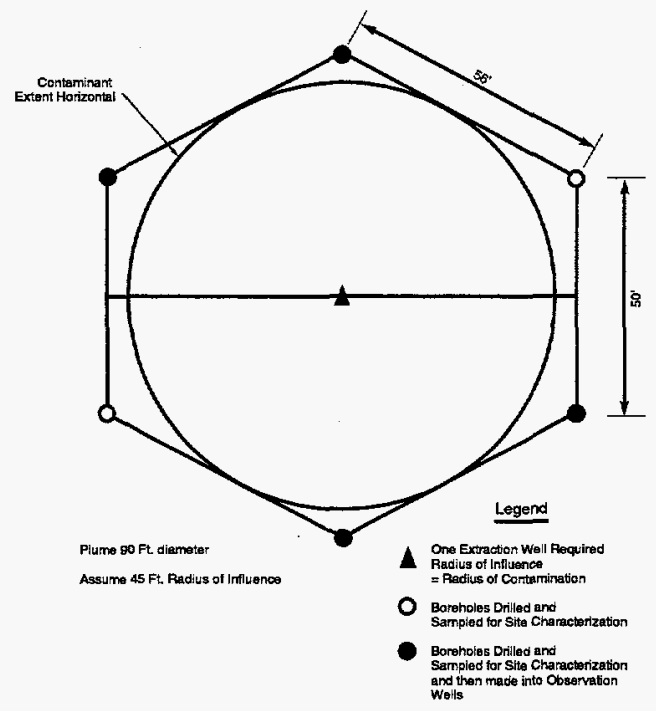

Figure 31. Contaminant Plume and RF Well Configuration

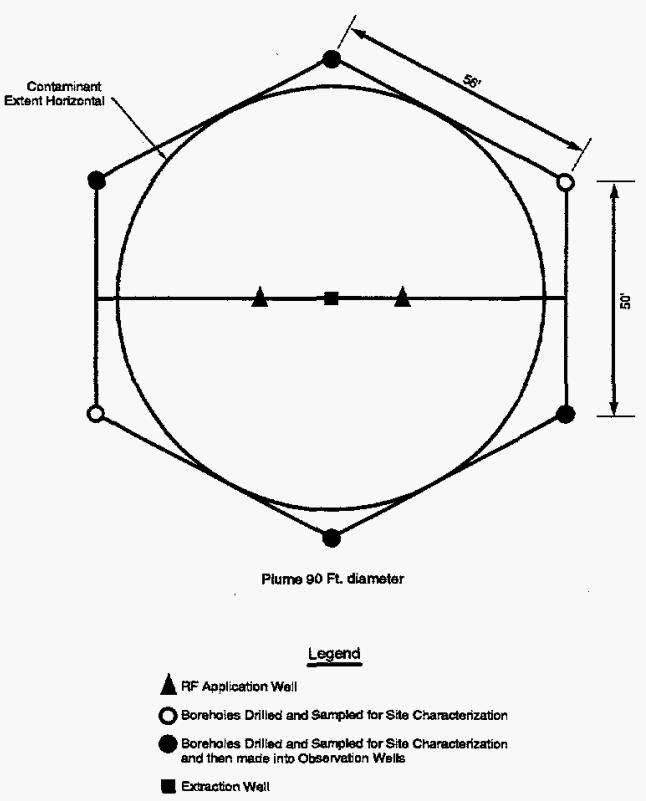

Figure 30. Contaminant Plume and LF Well Configuration

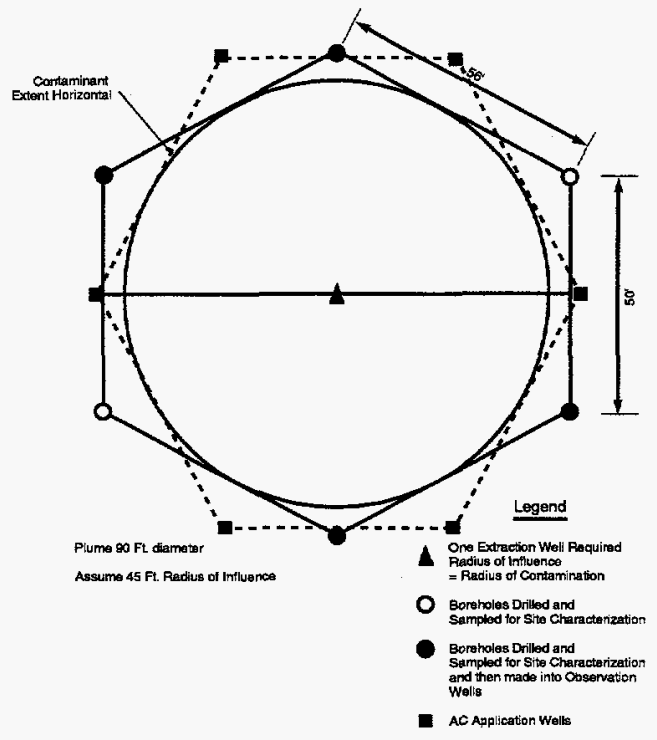

Figure 32. Contaminant Plume and DUS Well Configuration

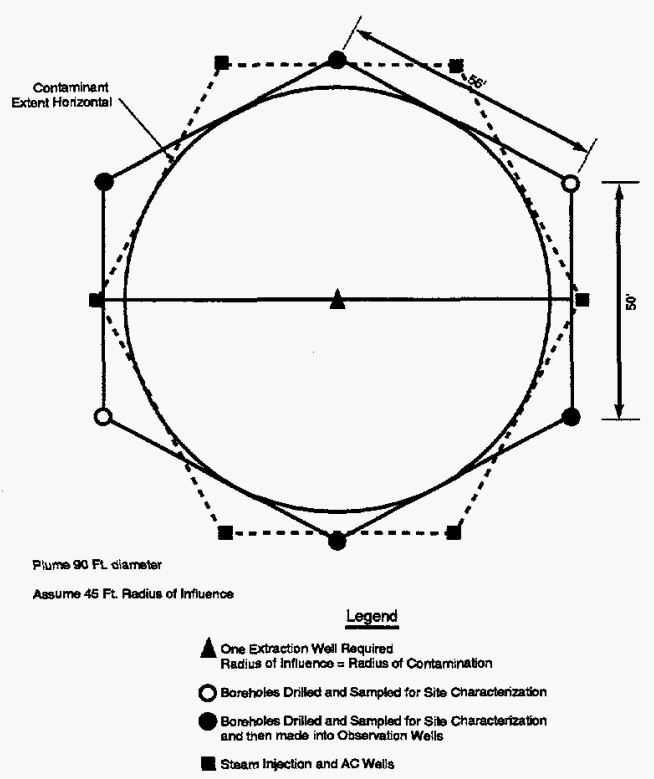




\subsection{Cost Information}

Cost comparisons will be between two types of technologies. The first technology cost estimate gives the cost associated with using one of the existing options, including SVE, E\&T, SVE/P\&T to remediate a particular site. The second technology cost estimate gives the cost associated with using one of the thermally enhanced technologies to remediate the site. The data will be presented in summary tabular form in this section of the report. The reader is asked to look in the appendix to determine the detailed costs of the various systems. The comparisons will be between the cost of using only the baseline technology for a typical period of time (5 years for SVE, 10 years for SVE treatment of SVOCs, and 1 year to complete an E\&T project) versus the cost of using a new thermal technology for a (different) period of time (6 months) to obtain some level of site remediation.

The shorter length of time attributed to the thermal technologies is the cost driver that generates their cost savings (except for Excavate and Treat which is just plain very expensive). Field results have shown that 6 months is a conservative guess for a typical campaign period for the thermally enhanced technologies. This is a factor of 10-20 faster than our base assumption of 5 years for normal SVE remediation programs. The factor of 10 is based upon the following rough physical process changes. Vapor pressure doubles about every $15^{\circ} \mathrm{C}$, so from subsurface US ambient temperatures of typically $12^{\circ} \mathrm{C}$ to near the boiling point of water, vapor pressure should be elevated by a factor of roughly 40-60 -- enhancing the speed of evaporation by the same factor and reducing remediation time by the same factor (and much more with the higher temperatures obtainable through RF heating). We derate this by a factor of 4 or so due to the likelihood of vapor diffusion being limited by soil permeability considerations -- leaving our conservative factor of 1020 improvement. Permeability increases less rapidly with temperature elevations, and in a much more unpredictable, non-linear, site-geology specific manner. Nonetheless, permeability and diffusion coefficients are also significantly raised by higher temperatures, and help rather than hinder the innovative remediation processes. No additional speed-cleaning credit is taken for the added effect of steam sweeping via the soil moisture or other water (direct injection of steam with DUS), although this is known to be important. The physics are difficult to model, but the bottom line empirical results clearly indicate that a total campaign time of 6 months is very reasonable. The typical conventional SVE time assumption of 5 years is more likely the understated number -- tight soil formations often make high levels of contaminant removal almost impossible -- and as more years of operation are run up, costs continue to rise long after the thermally enhanced technologies would have completed the job. Readers may extrapolate to longer or shorter remediation campaigns, but the basic flavor of the numerical results shown -- thermal enhancement saves a whole lot of time and therefore money -- will almost always continue to hold true. 
The detailed cost data for the various technologies are located in the Appendix. The following section present bottom line summary comparison of remediation costs for the technologies appropriate to each of the scenarios previously described.

Important notes on the following summary cost tables:

(1) "Site-Specific Capital Equipment Cost" refers to initial capital costs that are not transferable to any subsequent project (well drilling, mobilization, etc.). Usual analysis wraps these capital costs up with all other capital equipment and amortizes them over several years of project life. Because the thermal technology campaigns are less than a year in length, it is important to separate these costs from the "Reusable Capital Equipment" (water treatment skid, SVE skid, RF system, etc.). Reusable equipment will be used at other, future remediation locations and its cost is amortized over a five-year operating lifetime.

(2) "Capital Equipment Amortization Cost" is the normal roll-up of all capital expenditures for long-lived projects. This cost category is used for all of the conventional SVE technologies. Here the multiyear SVE campaigns do not have to concern themselves with the fact that wells and such are usable only at one specific site. These costs are captured/amortized over many years of operation because they are not in use only for a few months as is the unique case for the thermally enhanced technologies.

(3) "Unit Costs per Cubic Yard" should not be compared among/across the five different scenarios. Both baseline and thermally enhanced technologies have been matched to the specific scenarios for technology choice relevance and comparisons are only appropriate within each scenario. The remediation site scenarios are sufficiently different that it is not fair to compare specific technology cost estimates between remediation situations.

\subsubsection{Scenario 1. Shallow Vadose Contamination}

\begin{tabular}{|c|c|c|}
\hline $\begin{array}{l}\text { Shallow Vadose Co } \\
\text { Parameters }\end{array}$ & $\begin{array}{c}\text { tamination } \\
\text { TEVES } \\
\text { (RF \& } 3 \text { Phase) }\end{array}$ & $\begin{array}{l}\text { Excavate } \\
\text { and Treat }\end{array}$ \\
\hline \multirow{2}{*}{$\begin{array}{l}\text { Site-Specific Capital Equipment Cost } \\
\text { Reusable Capital Equipment Amortization Cost } \\
\text { Capital Equipment Amortization Cost } \\
\text { Operation and Maintenance Cost } \\
\qquad \text { Total Cost to Remediate } \\
\text { Unit Cost per Cubic Yard }\end{array}$} & $\begin{array}{c}\$ 464,800 \\
\$ 99,400 \\
\$ 215,100\end{array}$ & $\begin{array}{r}\$ 145,100 \\
\$ 150,500 \\
\$ 3,176,700\end{array}$ \\
\hline & $\begin{array}{c}\$ 779,300 \\
\$ 130 \\
\end{array}$ & $\begin{array}{c}\$ 3,472,300 \\
\$ 590 \\
\end{array}$ \\
\hline $\begin{array}{l}\text { Cubic Yards } \\
\text { Time Frame }\end{array}$ & $\begin{array}{c}5,900 \\
6 \text { months }\end{array}$ & $\begin{array}{c}5,900 \\
12 \text { months }\end{array}$ \\
\hline
\end{tabular}

E\&T costs more than 4 times as much as TEVES. Capital costs are somewhat higher for TEVES, but this difference is totally swamped by the huge operating costs (much labor and expensive equipment rental services) involved in E\&T's brute force excavation and treatment of every yard of contaminated soil. 


\subsubsection{Scenario 2. Deep Vadose Zone with VOC Contamination}

\begin{tabular}{|c|c|c|c|}
\hline Deep Vadose Zone $\mathrm{n}$ & $\begin{array}{l}\text { VOC Cor } \\
3 \text { Phase } \\
\text { AC Soll } \\
\text { Heating }\end{array}$ & $\begin{array}{l}6 \text { Phase } \\
\text { AC Soil } \\
\text { Heating }\end{array}$ & $\begin{array}{l}\text { Soil Vapor } \\
\text { Extraction }\end{array}$ \\
\hline \multirow{2}{*}{$\begin{array}{l}\text { Site-Specific Capital Equipment Cost } \\
\text { Reusable Capital Equipment Amortization Cost } \\
\text { Capital Equipment Amortization Cost } \\
\text { Operation and Maintenance Cost } \\
\text { Total Cost to Remediate }\end{array}$} & $\begin{array}{c}\$ 535,300 \\
\$ 72,700 \\
\\
\$ 101,700\end{array}$ & $\begin{array}{c}\$ 535,300 \\
\$ 89,900 \\
\$ 101,700\end{array}$ & $\begin{array}{l}\$ 634,800 \\
\$ 888,500\end{array}$ \\
\hline & $\begin{array}{c}\$ 709,700 \\
\$ 24\end{array}$ & $\begin{array}{c}\$ 726,900 \\
\$ 25\end{array}$ & $\begin{array}{c}\$ 1,523,300 \\
\$ 53\end{array}$ \\
\hline $\begin{array}{l}\text { Cubic Yards } \\
\text { Time Frame }\end{array}$ & $\begin{array}{c}29,000 \\
6 \text { months }\end{array}$ & $\begin{array}{c}29,000 \\
6 \text { months }\end{array}$ & $\begin{array}{l}29,000 \\
5 \text { years }\end{array}$ \\
\hline
\end{tabular}

Standard SVE costs more than twice as much as either of the 3 or 6 phase LF technologies to complete a remediation campaign. Capital costs are similar for all of these technologies, but operating and maintenance costs balloon for SVE as it runs on-and-on over our assumed 5 years becoming almost 9 times as big as the LF operating costs projected during a 6 month thermally enhanced project life.

\subsubsection{Scenario 3. Deep Vadose Zone with SVOC Contamination}

\begin{tabular}{|c|c|c|}
\hline Deep Vadose Zone with SVOC & $\begin{array}{l}\text { Oontaminatio } \\
\text { Radio } \\
\text { Frequency } \\
\text { Heating }\end{array}$ & $\begin{array}{l}\text { Soil Vapor } \\
\text { Extraction }\end{array}$ \\
\hline \multirow{3}{*}{ 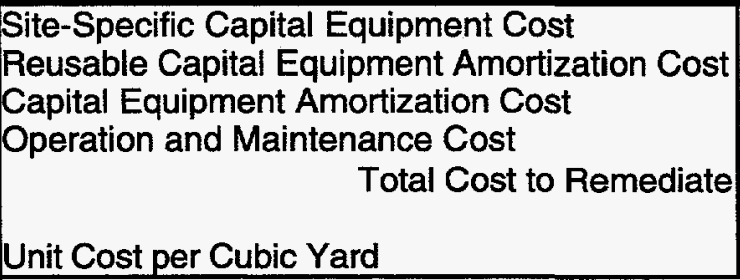 } & $\begin{array}{l}\$ 379,900 \\
\$ 113,900 \\
\$ 107,900 \\
\end{array}$ & $\begin{array}{c}\$ 634,800 \\
\$ 1,657,100 \\
\end{array}$ \\
\hline & $\$ 601,700$ & $\$ 2,291,900$ \\
\hline & $\$ 21$ & $\$ 79$ \\
\hline $\begin{array}{l}\text { Cubic } \\
\text { Time }\end{array}$ & $\begin{array}{c}29,000 \\
6 \text { months } \\
\end{array}$ & $\begin{array}{c}29,000 \\
10 \text { years } \\
\end{array}$ \\
\hline
\end{tabular}

Standard SVE costs are about 4 times those of RF technology -- and probably do not even can achieve the same level of cleanup. In this case we let SVE run for 10 years due to the lesser volatility of SVOC at ambient temperatures compared to more volatile VOCs and our usual 5 year assumption for VOCs. This longer time period adds even more to SVE's costs, while RF still can get the job done in only 6 months, saving huge amounts of operating and maintenance expenses. 


\subsubsection{Scenario 4. Deep Vadose/Groundwater Contamination}

\begin{tabular}{|c|c|c|}
\hline Deep Vadose Zone with Groun & $\begin{array}{l}\text { water Contamir } \\
\text { Dynamic } \\
\text { Underground } \\
\text { Stripping }\end{array}$ & $\begin{array}{l}\text { ion } \\
\text { Soil Vapor } \\
\text { Extraction } \\
\text { (Pump \& Treat) }\end{array}$ \\
\hline \multirow{3}{*}{$\begin{array}{l}\text { Site-Specific Capital Equipment Cost } \\
\text { Reusable Capital Equipment Amortization Cost } \\
\text { Capital Equipment Amortization Cost } \\
\text { Operation and Maintenance Cost } \\
\qquad \text { Total Cost to Remediate } \\
\text { Unit Cost per Cubic Yard }\end{array}$} & $\begin{array}{l}\$ 703,800 \\
\$ 112,200 \\
\$ 274,800 \\
\end{array}$ & $\begin{array}{l}\$ 776,000 \\
\$ 888,500 \\
\end{array}$ \\
\hline & $\$ 1,090,800$ & $\$ 1,664,500$ \\
\hline & $\$ 38$ & $\$ 57$ \\
\hline $\begin{array}{l}\text { Cubic Yards } \\
\text { Time Frame }\end{array}$ & $\begin{array}{c}29,000 \\
6 \text { months }\end{array}$ & $\begin{array}{l}29,000 \\
5 \text { years }\end{array}$ \\
\hline
\end{tabular}

SVE with Pump and Treat costs more than 50\% more than DUS in our scenario. Capital costs for the two technologies are very similar, but again the operating costs mount up as the SVE campaign stretches over 5 years, while the higher rate of operating expenditures for DUS quickly come to an end as the remediation is completed within 6 months.

\subsubsection{Scenario 5. Restricted Access Contamination}

\begin{tabular}{|c|c|c|}
\hline Restricted Access Contamina & $\begin{array}{c}\text { on (beneath buil } \\
\text { Radio } \\
\text { Frequency } \\
\text { Dipole Heating }\end{array}$ & $\begin{array}{l}\text { g) } \\
\text { Soil Vapor } \\
\text { Extraction } \\
\text { (Res. Access) }\end{array}$ \\
\hline \multirow{2}{*}{$\begin{array}{l}\text { Site-Specific Capital Equipment Cost } \\
\text { Reusable Capital Equipment Amortization Cost } \\
\text { Capital Equipment Amortization Cost } \\
\text { Operation and Maintenance Cost } \\
\qquad \begin{array}{l}\text { Total Cost to Remediate } \\
\text { Unit Cost per Cubic Yard }\end{array}\end{array}$} & $\begin{array}{c}\$ 258,800 \\
\$ 79,600 \\
\$ 107,900 \\
\end{array}$ & $\begin{array}{l}\$ 557,500 \\
\$ 888,500 \\
\end{array}$ \\
\hline & $\begin{array}{c}\$ 446,300 \\
\$ 890 \\
\end{array}$ & $\begin{array}{c}\$ 1,446,000 \\
\$ 2,900 \\
\end{array}$ \\
\hline $\begin{array}{l}\text { Cubic Yards } \\
\text { Time Frame }\end{array}$ & $\begin{array}{c}500 \\
6 \text { months }\end{array}$ & $\begin{array}{c}500 \\
5 \text { years }\end{array}$ \\
\hline
\end{tabular}

The small volume of difficult to reach contaminant suffers the highest unit costs of remediation of the scenarios examined in this report. The conventional technology of SVE in using angled wells costs more than 3 times as much as using the RFD technology. The compact, targeted RF dipole antenna cuts RFD capital costs to about half those of SVE. And, as usual, the short time needed to deploy and complete RFD compared to 5 years of SVE results in operating and maintenance costs that are more than 8 times cheaper than the conventional SVE technology. 


\section{Future Developments and Technology Risks}

One concern that is repeatedly brought out in the literature is the need for a detailed characterization of the site prior to the installation of the actual thermally enhanced remediation system or systems. This characterization should include the following:

core samples (taken as the wells are being drilled)

laboratory testing

contaminant identification (VOC, SVOC, etc.)

geographic boundaries

computer modeling of the geology and remediation of the site

Core samples can be taken from the wells as the remediation systems are constructed. From these core samples the general lithology of the site can be determined. The core samples would also provide the necessary target material for laboratory testing.

Laboratory testing should be performed to determine the chemical composition of the contaminants and other material present at the site, electrical and dielectric properties of the formation, as well as other information that will be required to determine the most appropriate technology or technologies to use.

The outer boundaries of the actual contaminant plume or volume must be determined fairly precisely. It should be remembered that the total volume that is to be treated (both contaminated and uncontaminated volumes) will determine the length of time necessary to remediate the site, as well as the total cost of the remediation process. As an example, while most underground storage tank plumes take on the general appearance of an inverted cone, the system that would be employed to remediate the site would take on the shape of a cylinder that completely encompasses the plume. It may be possible to use non-vertical wells to reduce the amount of soil volume that is actually treated, but, so far, no one has tried to use anything other than a vertical or horizontal well configurations, and the one attempt to use a horizontal well configuration proved to be very difficult to use.

Once the above information is at hand, computer models should be run to determine the best strategy to employ for remediating the site. We envision the development and commercialization of a total package system. This total package system would include the facilities necessary for site characterization, computer modeling, as well as the actual equipment necessary to install and operate any of the new technologies, as well as any new technologies that might be developed in the future. 


\section{Geologic Setting}

The geologic settings will vary from site to site. Special concerns include the presence of a source of water (for a water drip in the LF system and for the creation of steam in the DUS system), a source of electricity, and a source of fuel should a boiler be employed. Beyond these restrictions, any of these systems might be applicable, depending on the contaminants at the site.

Furthermore, each of these systems are subject to the same limitations on lithology. The site lithology is the single most important factor when considering whether to and where to drill the various wells. Permeability and natural water content must be taken into consideration. Any site that has shale layers (or layers that have consolidated sediments or other hard/drill resistant natural materials) will pose problems for drilling the wells. This difficulty would have a larger impact on the technologies that use multiple wells.

\section{Health Risk Reduction}

Each of the new technologies discussed in this report is subject to differing sets of health risk reduction requirements. While each may be better than E\&T by virtue of the fact that the soil is treated in situ, and each may be better than P\&T by virtue of the fact that the site is remediated before the contaminants have had a chance to reach the water table, there are still concerns that must be addressed before selecting any one technology as being superior to the others. In the case of SVE, a significant concern about the possibility of the contaminant reaching the water table during a period when the system is not operating must be addressed.

The new technologies all use large amounts of electrical power to achieve the enhanced remediation affects. Concerns about the safety of these high power systems, the effects that they might have on workers and the environment in general must be addressed. For example, in the DUS system, the periods of LF heating and steam injection must be consecutive rather that concurrent as the possibility of conducting electricity to the surface and injuring workers at the site exists.

The effects of radio frequency transmissions on the environment and on workers is also significant. Radio frequency radiation, in sufficiently high doses, can cause a large number of deleterious effects ranging from headaches to other, more serious, forms of illness. Hence, high power radio energy is being transmitted to the surface from the submerged application antennae, the workers' safety will require either shielding or their removal off the site during the operation of the radio frequency equipment. Effects of RF energy on animal life forms other than human might also be considered.

Finally, conditions at the site may require escalated levels of worker protection. This report assumes that level $\mathrm{D}$ precautions are adequate. If more stringent forms of protection are required, 
the costs associated with installing, monitoring, maintaining, disassembling and dismantling the equipment must also be considered and increased by appropriate factors.

\section{Regulatory Approval}

Any new technology must gain regulatory approval from state and national organizations prior to being deployed to a given site. This is true of the baseline technologies as well as the new technologies. However, at this time, SVE, P\&T, and E\&T are fairly widely accepted means of site remediation, while the new technologies are sufficiently more complex. We estimate that gaining regulatory approval to use any of the new technologies will be more difficult than for SVE. For example, the LF system will require approval to use electrical energy to resistively heat the formation. DUS must, in addition to this, gain approval to use a steam injection system. At a minimum we expect that, to use DUS, it will be necessary to show that the injection of steam into the formation will not cause the contaminated volume to expand. The two RF systems will require permits allowing the use of radio frequency signals at the frequency or frequencies to be used at the site.

\section{Conclusions}

The five technologies discussed in this report use SVE, but introduce added energy in the form of heat into the soil formation. These technologies are Low Frequency (LF or Ohmic) Heating, Dynamic Underground Stripping (DUS), Radio Frequency Heating (RF), Radio Frequency Heating using Dipole Antennae (RFD), and Thermally Enhanced Vapor Extraction System (TEVES), a combination of LF and RF. Each of these technologies can be coupled with SVE to improve performance. Each has different niches in which it is most effective and appropriate for application.

The tables in section 6.1 summarize the cost-savings advantages of the new, thermally enhanced remediation technologies for particular scenarios. In each case the thermally enhanced technologies are appropriate technological substitutes for the specific conventional technologies they are compared with in these scenarios. In every case the thermal technologies are significantly less expensive than the conventional technologies. 


\section{Bibliography}

Aines R., et. al.; "Dynamic Underground Stripping Demonstration Project"; UCRL-ID-109906; Lawrence Livermore National Laboratory (March 1992).

Darman, R. ed, Office of Management and Budget Circular No. A-94, "Discount Rates of CostEffectiveness, Lease Purchase, and Related Analysis," to Heads of Executive Departments and Establishment (March 1994). Updated by OMB Circular No. A-94 (February 1996).

Heath, W.O., D. E. Lessor, J. S. Roberts, T. M. Bergsman; "Engineering Scaleup of Electrical Soil Heating for Soil Decontamination; PNL-SA-20740 (August 1992).

Phelan, J.M., "Thermal Enhanced Vapor Extraction System," SAND--92-2773C (1992).

Phelan, J.M., and H. Dev, "Application of Thermal Enhanced Vapor Extraction System Technology on a Complex Chemical Waste Mixture," Preprint Extended Abstract, Presented at the I\&EC Special Symposium, American Chemical Society, Atlanta, GA, September 17-20, 1995.

Rosenberg, N., "Comments on Thermally enhanced In Situ Soil Remediation Technologies," Memorandum (July 31, 1995).

Sresty, G., H. Dev, J. Houthoof, D., "In Situ Soil Decontamination By Radio Frequency Heating" (February 1992).

U.S. Department of Energy (1995a), "Dynamic Underground Stripping: Innovative Technology Summary Report," Office of Environmental Management, Office of Technology Development, (April 1995).

U.S. Department of Energy (1995b), "Six Phase Soil Heating: Innovative Technology Summary Report," Office of Environmental Management, Office of Technology Development (April 1995). 


\section{Appendix. Detailed Systems' Costs}

The detailed systems' costs come from a variety of sources and were prepared by IT Corp., Albuquerque, NM.

Scenario 1 Detailed Costs -- Shallow Vadose Contamination

TEVES (RF and 3 Phase AC) Heating Costs

Excavate and Treat Costs

Scenario 2 Detailed Costs -- Deep Vadose Zone with VOC Contamination

3 Phase AC Heating Costs

6 Phase AC Heating Costs

Soil Vapor Extraction Costs

Scenario 3 Detailed Costs -- Deep Vadose Zone with SVOC Contamination Radio Frequency Heating Costs

Scenario 4 Detailed Costs -- Deep Vadose Zone with Groundwater Contamination Dynamic Underground Stripping Costs

Soil Vapor Extraction (Pump and Treat) Costs

Scenario 5 Detailed Costs -- Restricted Access Contamination (beneath building)

Radio Frequency Dipole Heating Costs

Soil Vapor Extraction (Restricted Access) Costs 
Scenario 1 Detailed Costs -- Shallow Vadose Contamination

TEVES -RF and 3 Phase AC Heating- Costs

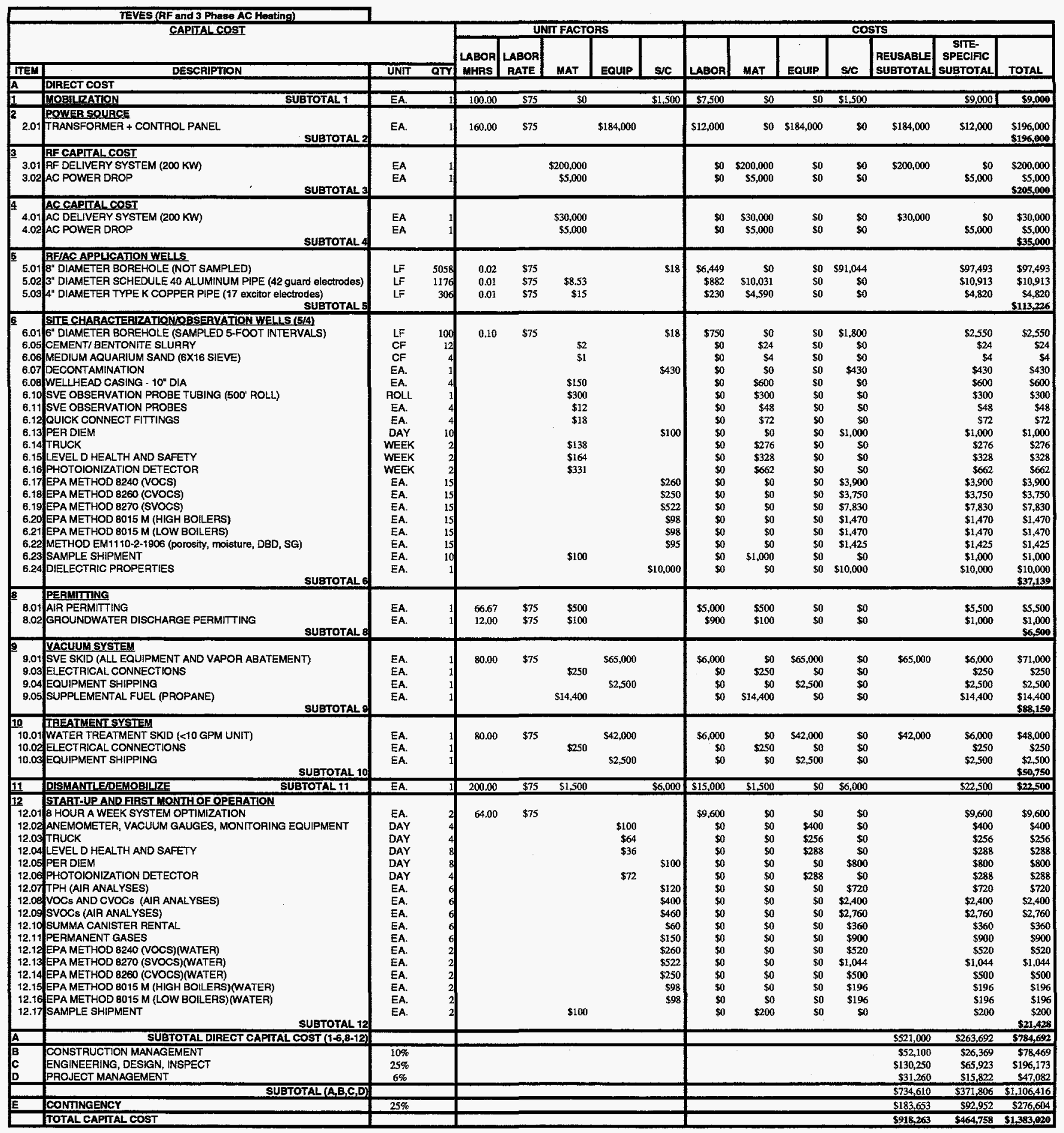


Scenario 1 Detailed Costs - Shallow Vadose Contamination

TEVES -RF and 3 Phase AC Heating-- Costs (continued)

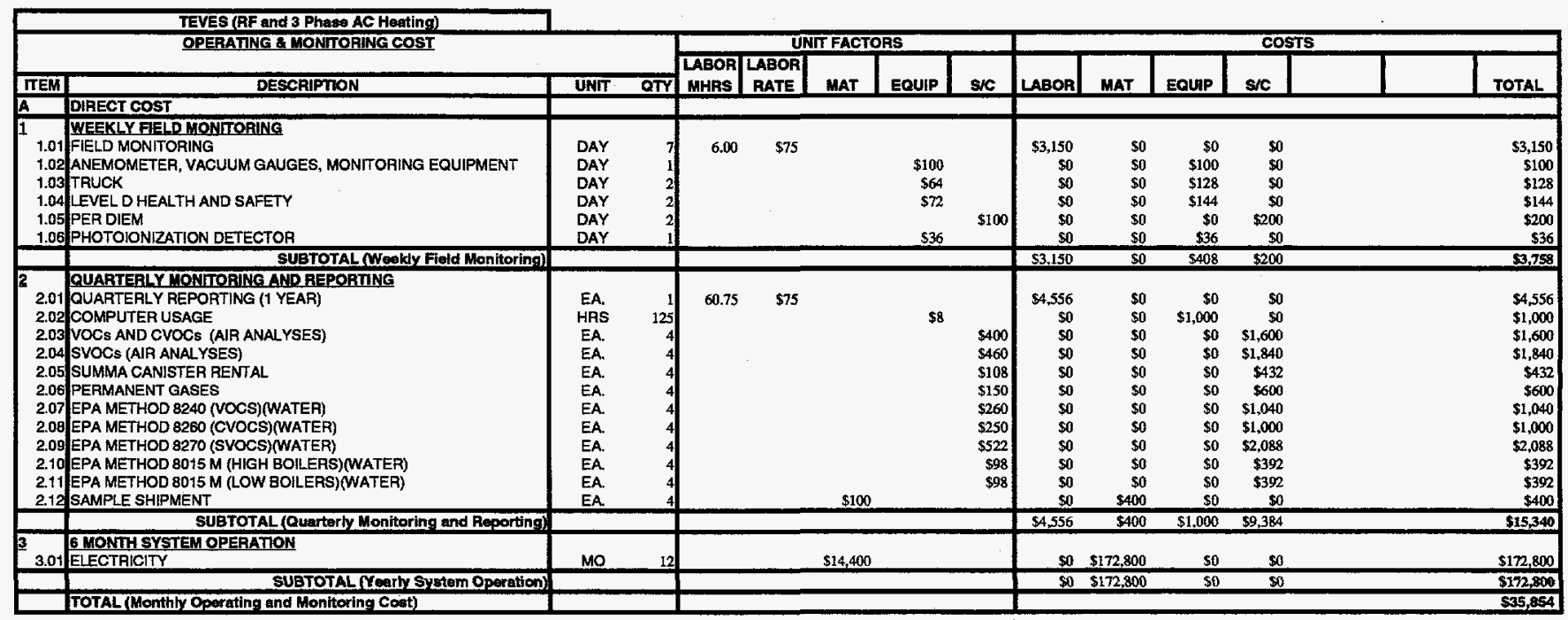

\begin{tabular}{|c|c|}
\hline $\begin{array}{l}\text { Capital Equipment } \\
\text { Yearly interest Rate } \\
\text { Amortization Period (Years) }\end{array}$ & $\begin{array}{r}\$ 918,263 \\
3 \% \\
5 \\
\end{array}$ \\
\hline Yeariy Payment & $\$ 198,792$ \\
\hline Total Amortized Equipment Cost & $\$ 993,962$ \\
\hline Total Amortized Equipment Cost (per month) & $\$ 16,566$ \\
\hline \multicolumn{2}{|l|}{ TEVES (RF and 3 Phaee) Heating Costs } \\
\hline $\begin{array}{l}\text { Site-Specific Capital Equipment Cost } \\
\text { Reusable Capital Equipment Amortization Cost (6 menths) } \\
\text { Operation and Maintenance Cost (6 months) }\end{array}$ & $\begin{array}{r}\$ 464,758 \\
\$ 99,396 \\
\$ 215,124\end{array}$ \\
\hline Total Cost to Remediate & $\$ 779,278$ \\
\hline it Cost per Cubic Yard (5,900 cubic yards) & $\$ 132$ \\
\hline
\end{tabular}


Scenario 1 Detailed Costs - Shallow Vadose Contamination Excavate and Treat Costs

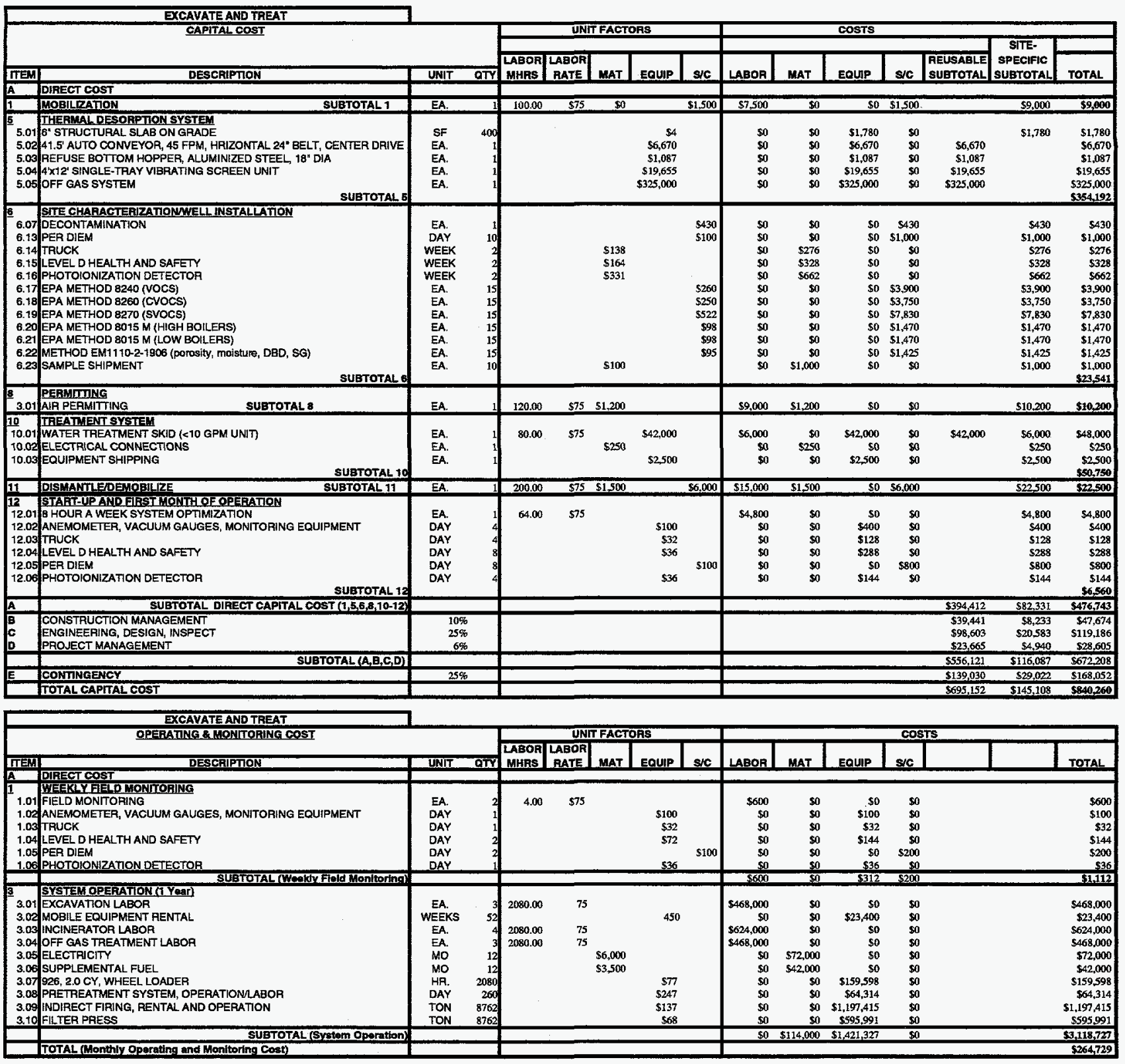

\begin{tabular}{|c|}
\hline $\begin{array}{l}\text { Capital Equipment } \\
\text { Yearly Interest Pate } \\
\text { Amontzation Period rears) }\end{array}$ \\
\hline Yearty Payment \\
\hline Total Amortized Equipment Cost \\
\hline Total Amortized Equifement cost (per month) \\
\hline Excavate and Troat Costs \\
\hline $\begin{array}{lr}\text { Site-Specific Capital Equipment Cost } & \$ 145,108 \\
\text { Reusable Capital Equipment Amortization Cost (12 months) } & \$ 150,492 \\
\text { Operation and Maintenance Cost (12 months) } \quad \text { Total Cost to Remediale } & \$ 3,176,749 \\
33,472,350\end{array}$ \\
\hline Unit Cost per Cubic Yard (5,900 euble yands) \\
\hline
\end{tabular}


-- End of Scenario 1 --

(This page intentionally left blank.) 


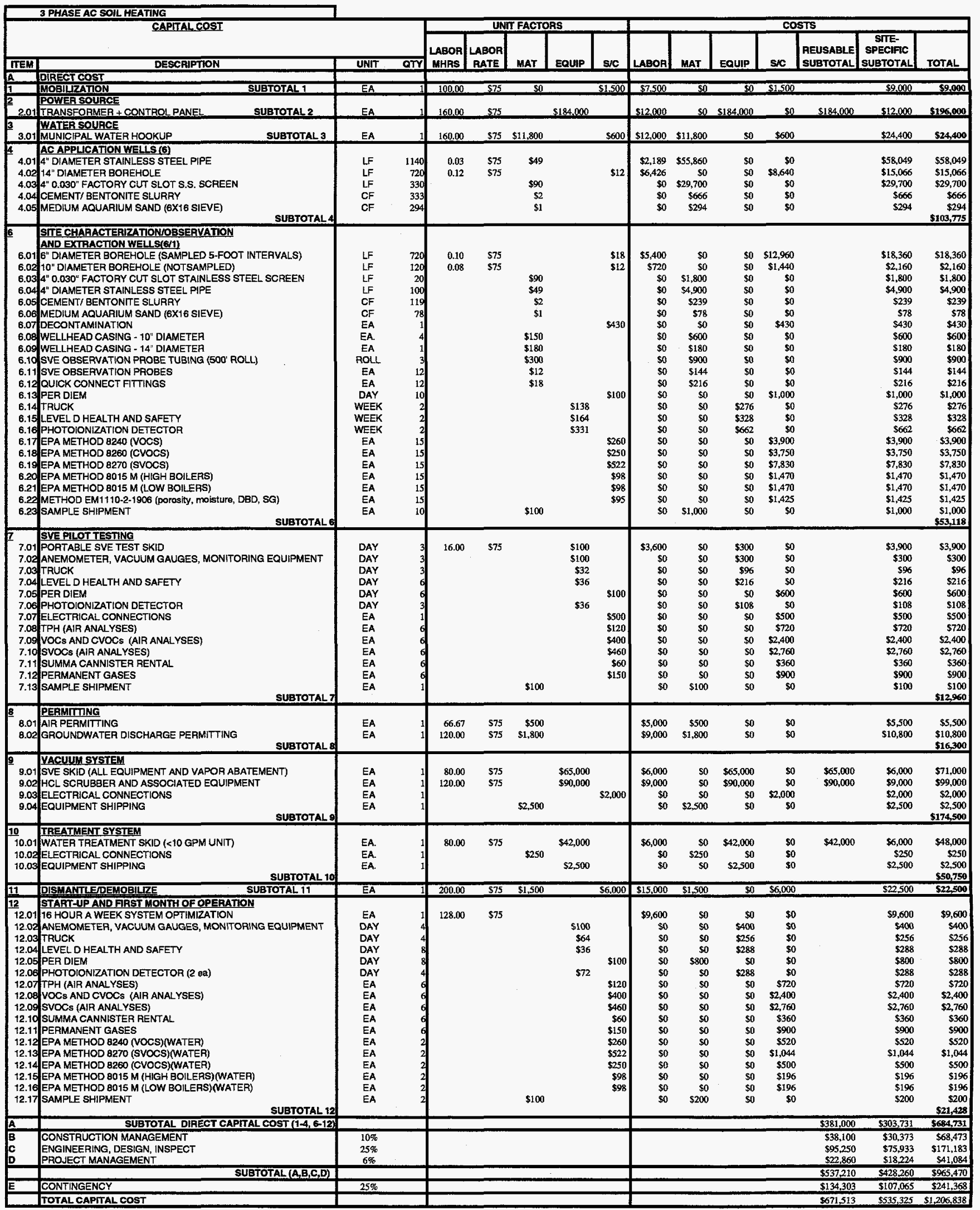


Scenario 2 Detailed Costs - Deep Vadose Zone with VoC Contamination

3 Phase AC Heating Costs (continued)

\begin{tabular}{|c|c|c|c|c|c|c|c|c|c|c|c|c|c|}
\hline & & & & LABOR & LABOR & & & & & & & & \\
\hline IIEM & DESCRIPTION & UNIT & QTY & MHAS & FATE & MAT & EQUIP & sic & LABOA & MAT & Quipe & sec & TOTAL. \\
\hline$\triangle$ & DIRECT COST & & & & & & & & & & & & \\
\hline 1 & WEEKLY FELEOMONITOARNG & & & & & & & & & & & & \\
\hline 1.01 & 4 HOURS FIELD MONITORING & EA & 2 & 4.00 & $\$ 75$ & & & & $\$ 600$ & \$o & so & \$o & $\$ 600$ \\
\hline 1.02 & ANEMOMETER, VACUUM GAUGES, MONITORING EQUIPMENT & DAY & & & & & $\$ 100$ & & $\$ 0$ & so & $\$ 100$ & $\$ 0$ & $\$ 100$ \\
\hline 1.03 & TRUCK & DAY & & & & & $\$ 64$ & & so & \$o & $\$ 128$ & $\$ 0$ & $\$ 128$ \\
\hline 1.04 & LEVELL D HEALTH AND SAFETY & DAY & 2 & & & & $\$ 36$ & & $\$ 0$ & so & $\$ 72$ & $\$ 0$ & $\$ 72$ \\
\hline 1.05 & PER DIEM & DAY & & & & $\$ 100$ & & & $\$ 0$ & $\$ 400$ & so & \$0 & $\$ 400$ \\
\hline 1.06 & PHOTOIONIZATION DETECTOR ( 2 ea) & DAY & & & & & $\$ 22$ & & \$o & 80 & $\$ 144$ & $\$ 0$ & $\$ 144$ \\
\hline & SUBTOTAL (Woekhy Field Monltoring) & & & & & & & & $\$ 600$ & $\$ 400$ & $\$ 444$ & 50 & $\$ 1.444$ \\
\hline 2 & QUARTEA Y Y MONITORING AND BEPQRATIKG & & & & & & & & & & & & \\
\hline 2.01 & QUARTERLY REPORTING & HR & 1 & 121.50 & $\$ 75$ & & & & $\$ 9,113$ & $\$ 0$ & so & $\$ 0$ & $\$ 9,113$ \\
\hline 2.02 & COMPUTER USEAGE & HR & 63 & & & & \$8 & & $\$ 0$ & \$0 & $\$ 500$ & $\$ 0$ & $\$ 500$ \\
\hline 2.03 & VOCS AND CVOCS (AIR ANALYSES) & EA & & & & & & $\$ 400$ & \$o & so & so & $\$ 800$ & $\$ 800$ \\
\hline 2.04 & SVOCS (AIR ANAL YSES) & EA & 2 & & & & & $\$ 460$ & $\$ 0$ & \$o & so & $\$ 920$ & $\$ 920$ \\
\hline 2.05 & SUMMA GANNISTER RENTAL & EA & & & & & & $\$ 108$ & $\$ 0$ & $\$ 0$ & $\$ 0$ & $\$ 216$ & $\$ 216$ \\
\hline 2.06 & PERMANENT GASES & EA & & & & & & $\$ 150$ & so & \$o & so & $\$ 300$ & $\$ 300$ \\
\hline 2.07 & EPA METHOD 8240 (VOCS)(WATER) & EA & & & & & & $\$ 260$ & so & $\$ 0$ & so & $\$ \$ 20$ & $\$ 520$ \\
\hline 2.08 & EPA METHOD 8260 (CVOCS)(WATER) & EA & 2 & & & & & $\$ 250$ & so & \$0 & so & $\$ 500$ & $\$ 500$ \\
\hline 2.09 & (EPA METHOD B270 (SVOCS)(WATER) & EA & & & & & & $\$ 522$ & \$0 & \$0 & so & $\$ 1,044$ & $\$ 1,044$ \\
\hline 2.10 & EPA METHOD B015 M (HIGH BOLLEAS)(WATER) & EA & 2 & & & & & $\$ 98$ & so & $\$ 0$ & so & $\$ 196$ & $\$ 196$ \\
\hline 2.11 & EPA METHOD BO15 M (LOW BOILERS)(WATER) & EA & 2 & & & & & $\$ 98$ & so & $\$ 0$ & so & $\$ 196$ & $\$ 196$ \\
\hline 2.12 & SAMPLE SHIPMENT & EA & & & & $\$ 100$ & & & so & $\$ 200$ & so & so & $\$ 200$ \\
\hline & SUBTOTAL (Quarterly Lonitoring and Beporting) & & & & & & & & $\$ 9,113$ & $\$ 200$ & 5500 & $\$ 4.692$ & $\mathbf{5 1 4 , 5 0 5}$ \\
\hline 3 & YEARLY SYSTEM OPERATION & & & & & & & & & & & & \\
\hline 3.01 & ELECTRICITY (FOR $100 \mathrm{KW}$ O 50.08 ( KW.HA) & MO & & & & $\$ 5.837$ & & & so & $\$ 70.044$ & so & so & 570,044 \\
\hline & SUBTOTAL (Y Yearly System Oparation) & & & & & & & & so & $\$ 70,044$ & 50 & so & 570,044 \\
\hline & TOTAL (Monthily Oporating & & & & & & & & & & & & $\$ 16.951$ \\
\hline
\end{tabular}

\begin{tabular}{|c|c|}
\hline \multicolumn{2}{|l|}{ Aeusable Cap Equip Amortization and Periodic cost Computations } \\
\hline $\begin{array}{l}\text { Capital Equipment } \\
\text { Yearly Interest Rate } \\
\text { Amortization Period (Years) }\end{array}$ & $\begin{array}{r}8671,513 \\
3 \% \\
5\end{array}$ \\
\hline Yearby Paymont & $\$ 145,374$ \\
\hline Total Amortized Equipment Cost & $\$ 726,871$ \\
\hline Total Amortized Equilpment Coat (por month) & $\$ 12,115$ \\
\hline \multicolumn{2}{|l|}{3 Pheso AC Soll Heating Costs } \\
\hline $\begin{array}{l}\text { Sitte-Specific Capital Equipment Cost } \\
\text { Reusable Gapital Equipment Amortization Cost (6 mondhs) } \\
\text { Operation and Maintenance Cost (6 months) }\end{array}$ & $\begin{array}{r}\$ 535,325 \\
\$ 72,687 \\
\$ 101,704 \\
\end{array}$ \\
\hline Total Cost to Remediate & $\$ 709,716$ \\
\hline 9,000 cubic yards & \\
\hline
\end{tabular}




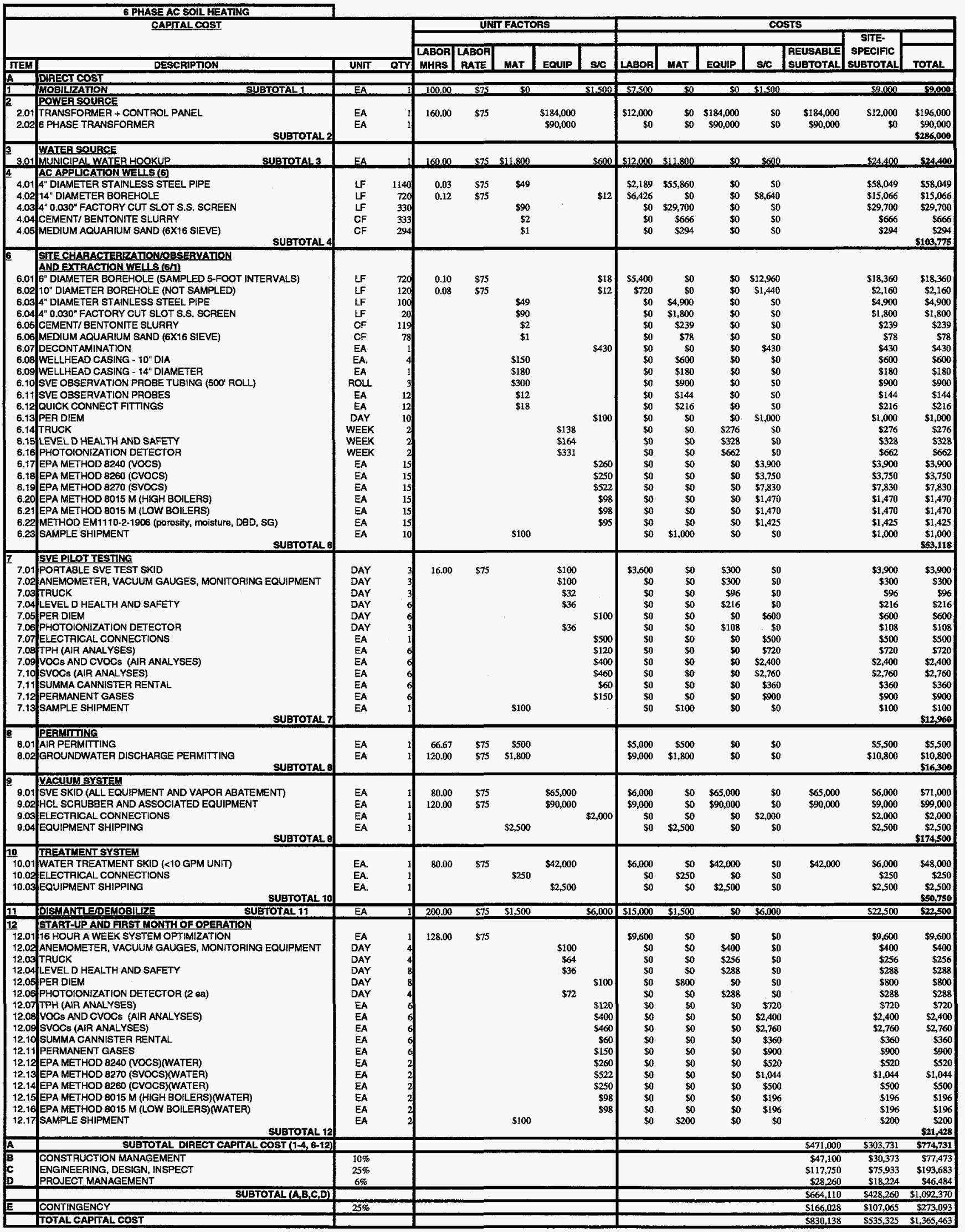




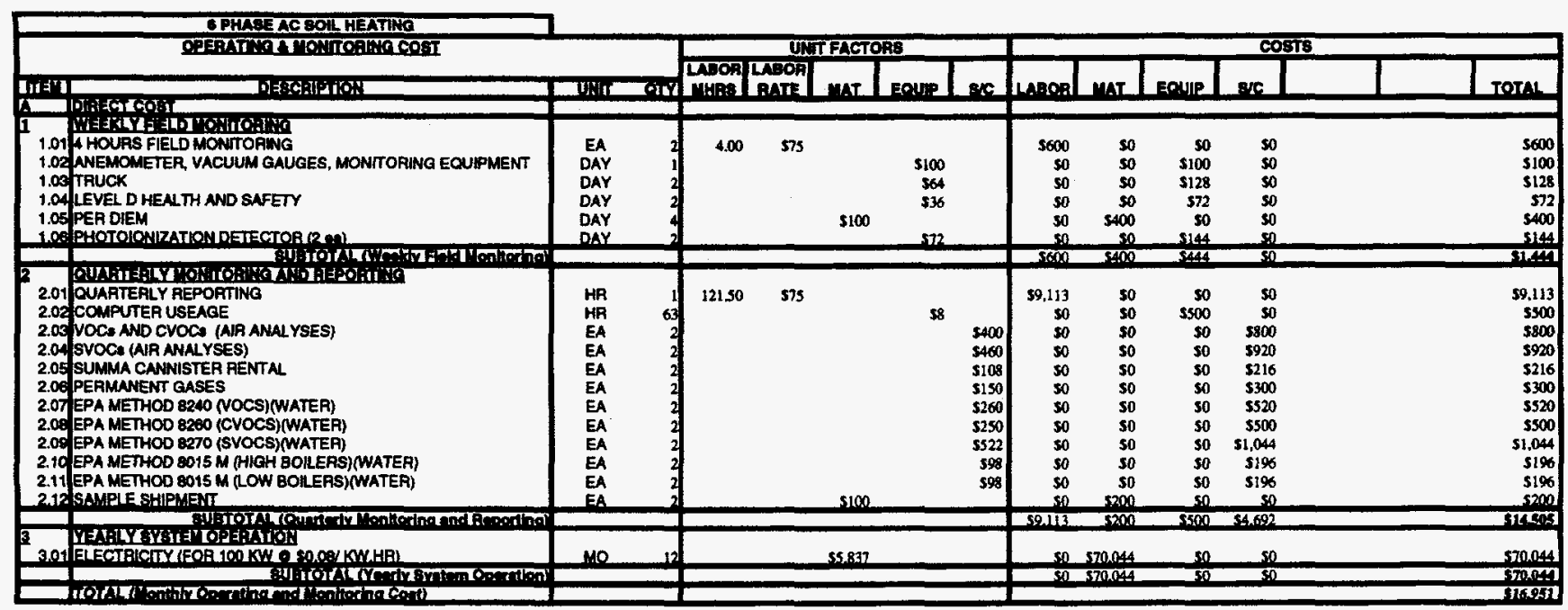

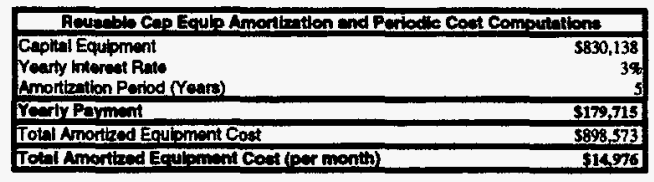

\begin{tabular}{|c|c|}
\hline \multicolumn{2}{|l|}{ GPhen AC Soll Henthe conte } \\
\hline 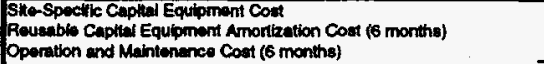 & 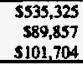 \\
\hline Total Cost to R & $\$ 726,886$ \\
\hline and $(29,000$ & \\
\hline
\end{tabular}




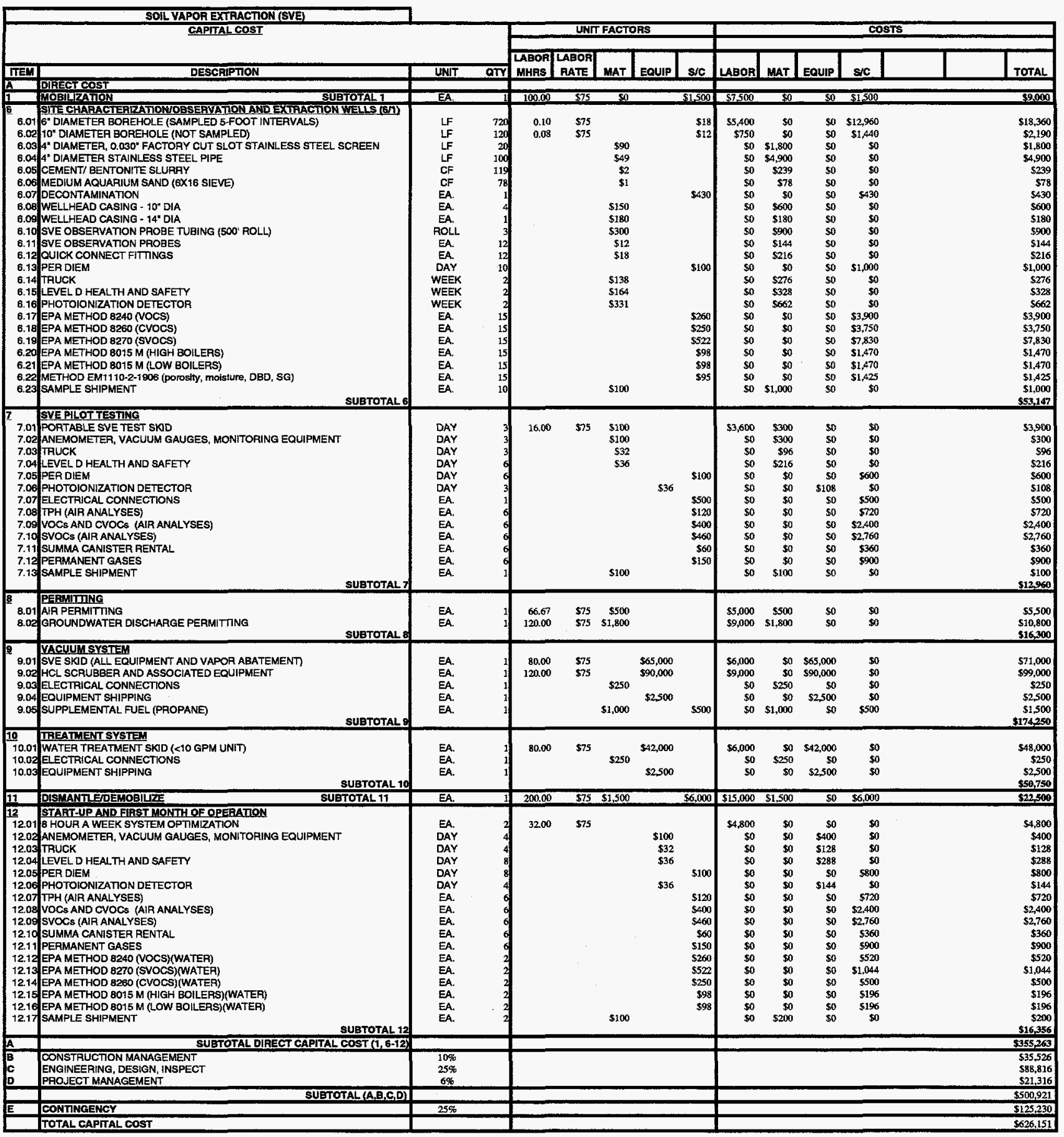




\begin{tabular}{|c|c|c|c|c|c|c|c|c|c|c|c|c|c|}
\hline & SOLL VAPOA EXTRACTION (SVE) & & & & & & & & & & & & \\
\hline & & & & & UNr & FACTC & & & & & & $\infty$ & \\
\hline TIEM & DESCDIFTOM & UNET & $\overline{G T Y}$ & LABOA & CABOA & MAT & Eoutp & $\because c$ & 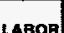 & MAT & EQUAP & ste & TOTAL \\
\hline A & DUIRECT COST & & & & & & & & & & & & \\
\hline 1 & WEEKL Y FHELOW MONITOAING & & & & & & & & & & & & \\
\hline $\begin{array}{l}1.01 \\
1.02\end{array}$ & 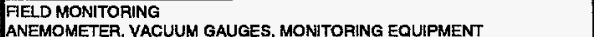 & $\begin{array}{l}\text { EA. } \\
\text { DAY }\end{array}$ & & 4.00 & $\$ 75$ & & $\$ 100$ & & $\$ \$ \$ 000$ & so & $\begin{array}{r}\$ 0 \\
\$ 100\end{array}$ & so & $\begin{array}{l}\$ 600 \\
\$ 100\end{array}$ \\
\hline 1.03 & THUCK & DAY & & & & & $\$ 32$ & & 50 & so & $\$ 32$ & so & $\$ 32$ \\
\hline 1.04 & LEVELL D HEALTH AND SAFETY & DAY & & & & & $\$ 72$ & & so & so & $\$ 144$ & so & $\$ 144$ \\
\hline 1.05 & PER DIEM & DAY & & & & & & $\$ 100$ & \$o & so & so & $\$ 200$ & $\$ 200$ \\
\hline 1.06 & PHOTOIONIZATION DETECTOR & DAY & & & & & $\$ 36$ & & 50 & so & $\$ 36$ & so & $\$ 36$ \\
\hline & SUGTOTAL (Woekdy Fleld Wonitoring) & & & & & & & & $\$ 600$ & 50 & $\$ 312$ & $\$ 200$ & $\$ 1.112$ \\
\hline$\underline{2}$ & QUARTERLY MONITOAINGANID AEPOFTING & & & & & & & & & & & & \\
\hline 2.01 & QUARTERLY HEPOPTING (1 YEAR) & EA. & & 121.50 & $\$ 75$ & & & & $\$ 9,113$ & so & $\$ 0$ & so & $\$ 9,113$ \\
\hline 2.02 & COMPUTER USAGE & HRS & so & & & & s8 & & & so & $\$ 2,000$ & so & $\$ 2,000$ \\
\hline 2.03 & VOCS AND CVOCS (AIR ANALYSES) & EA. & & & & & & $\$ 400$ & so & so & 50 & $\$ 3,200$ & $\$ 3,200$ \\
\hline 2.04 & SVOCs (AIR ANALYSES) & EA. & & & & & & $\$ 460$ & \$o & $\$ 0$ & $\$ 0$ & $\$ 3,680$ & $\$ 3,680$ \\
\hline 2.05 & SUMMA CANISTER FENTAL & EA. & & & & & & $\$ 108$ & so & so & so & $\$ 864$ & $\$ 864$ \\
\hline 2.06 & PERMANENT GASES & EA. & & & & & & $\$ 150$ & \$o & \$o & so & $\$ 1,200$ & $\$ 1,200$ \\
\hline 2.07 & EPA METHOD 8240 (VOCS)(WATER) & EA. & & & & & & $\$ 260$ & so & $\$ 0$ & \$o & $\$ 2,080$ & $\$ 2,080$ \\
\hline 2.08 & EPA METHOD 8260 (CVOCS) WATER) & EA. & & & & & & $\$ 250$ & so & so & so & $\$ 2,000$ & $\$ 2,000$ \\
\hline 2.09 & EPA METHOD 8270 (SVOCS)(WATEA) & EA. & & & & & & $\leqslant \leq 22$ & 50 & so & so & $\$ 4,176$ & $\$ 4,176$ \\
\hline 2.10 & EPA METHOD 8015 M (HIGH QOILERS)(WATER) & EA. & & & & & & 598 & $\$ 0$ & $\$ 0$ & so & $\$ 784$ & $\$ 784$ \\
\hline & (EPA METHOD 8015 M (LOW BOILERS)(WATER) & EA & & & & & & 598 & 8 & 80 & $\$ 0$ & 5784 & 5784 \\
\hline m & SAMPLE SHIPMENT & EA. & & & & $\$ 100$ & & & 80 & $\$ 800$ & 50 & 50 & 5800 \\
\hline & SUITOTAL (Quarterly Monltoring and Reporting) & & & & & & & & $\$ 9,113$ & $\$ 8800$ & 52,000 & $\$ 18.768$ & 530,681 \\
\hline$\underline{3}$ & PEARIYY SYSTIM OPPFATIOH & & & & & & & & & & & & \\
\hline "3.01 & ELECTRICITY & & 12 & & & $\$ 250$ & & & & & so & so & $\$ 3,000$ \\
\hline 3.02 & SUPPLEMENTAL FUEL & MO & & & & $\$ 500$ & & & & $\$ 6,000$ & so & $\$ 0$ & $\$ 6,000$ \\
\hline & SUBTOTAL Yearily SYEten Operation! & & & & & & & & 80 & $\$ 9,000$ & so & so & $\$ 9,000$ \\
\hline & TOTAL Chonthly Operating and Monltoring & & & & & & & & & & & & 515.812 \\
\hline
\end{tabular}

\begin{tabular}{|c|c|}
\hline $\begin{array}{l}\text { Caphtal Equipment } \\
\text { Yeary interest Pato } \\
\text { Amorization Period (Years) }\end{array}$ & $\begin{array}{r}\$ 626,151 \\
3 \% \\
5 \\
\end{array}$ \\
\hline Yoerity Paymont & $\$ \mathbf{5 1 3 5 , 5 5}$ \\
\hline Total Amortized Equipment cost & $\$ 677,7$ \\
\hline Total Amortzed Egulpment Cost & 511,29 \\
\hline
\end{tabular}

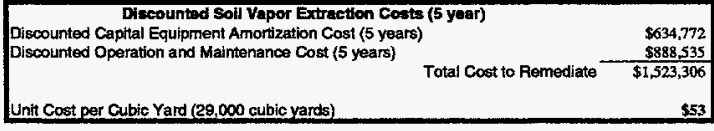

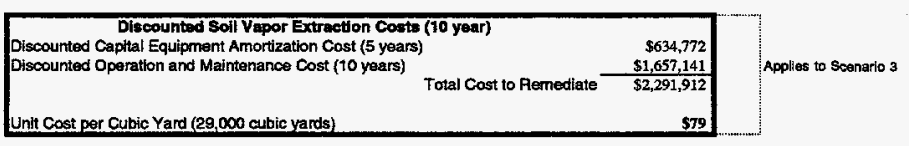




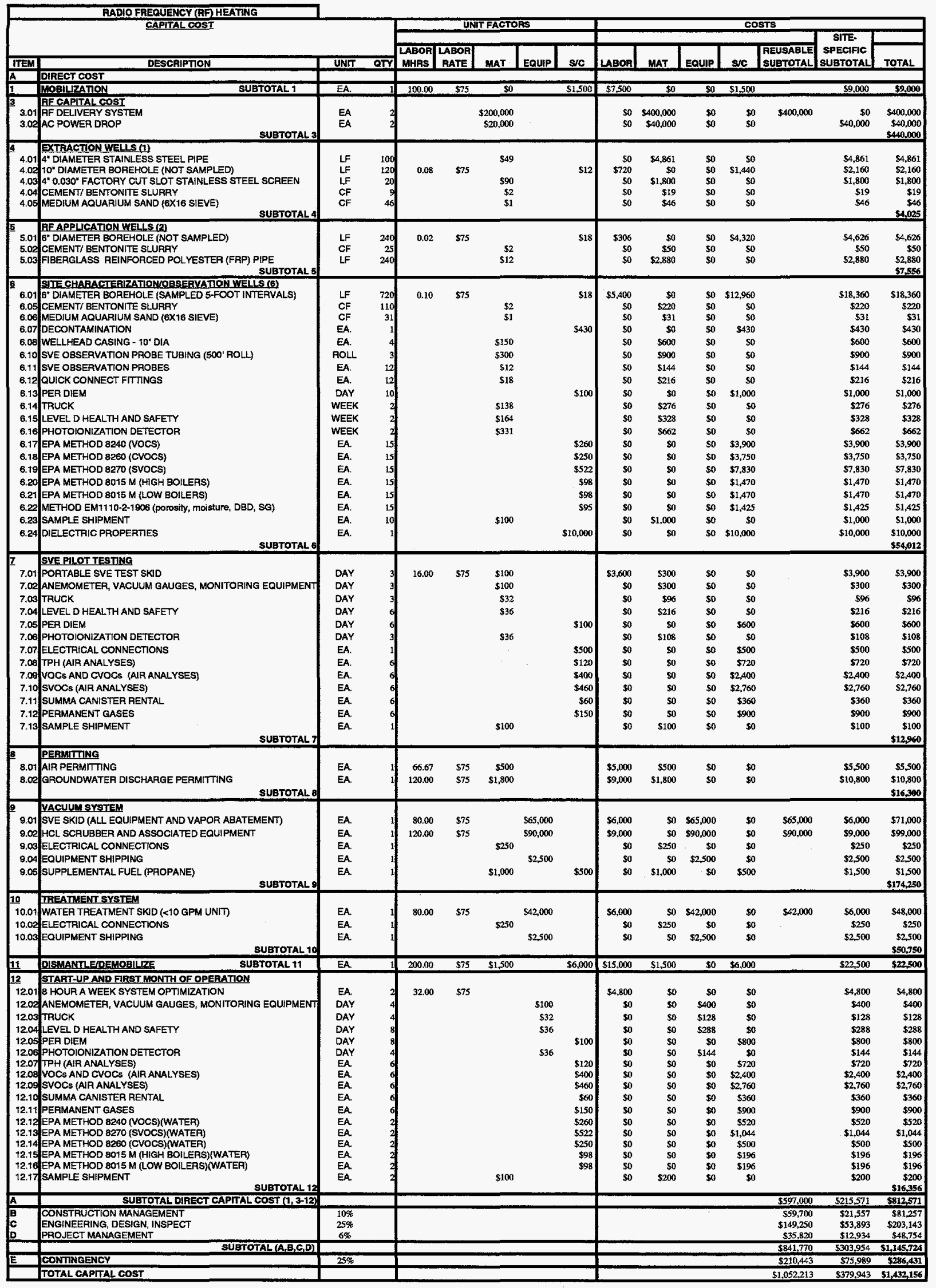


Scenario 3 Detailed Costs -- Desp Vadose Zone with Svoc Contamination

fadio Frequency Heating Costs (comtinued)

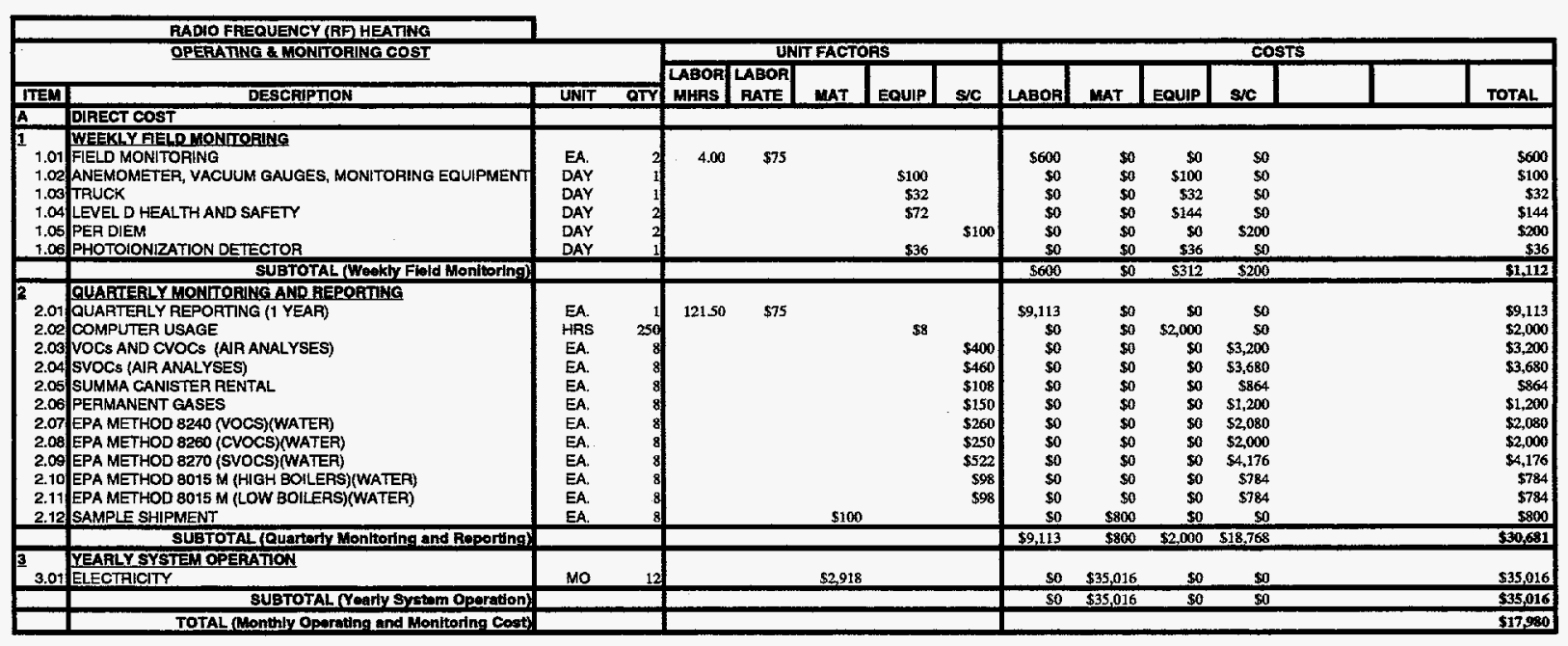

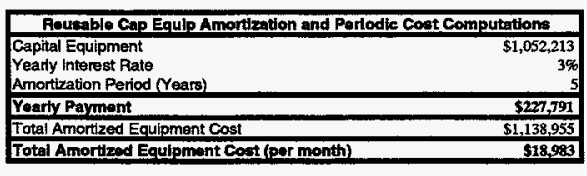

\begin{tabular}{|c|c|}
\hline \multicolumn{2}{|l|}{ Padio Frequencr Heatlag Conts } \\
\hline 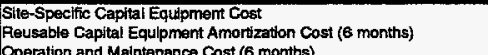 & $\begin{array}{l}5379,943 \\
5113,896 \\
107890\end{array}$ \\
\hline 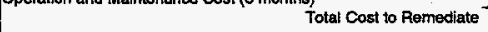 & $\$ 601.719$ \\
\hline it Cost per Cubic Yard $(29,000$ cubic yar & 521 \\
\hline
\end{tabular}




\begin{tabular}{|c|c|c|c|c|c|c|c|c|c|c|c|c|c|c|}
\hline \multicolumn{3}{|c|}{$\begin{array}{c}\text { DYNAMIC UNDERGROUND STRIPPING } \\
\text { CAPITAL COST }\end{array}$} & \multirow{2}{*}{\multicolumn{5}{|c|}{ UNITFACTORS }} & \multirow{2}{*}{\multicolumn{7}{|c|}{ COSTS }} \\
\hline \multirow{3}{*}{ TIEM } & \multirow{4}{*}{ DEScRIPTION } & \multirow[b]{3}{*}{ एत्र कत्र } & & & & & & \multirow{3}{*}{ LABOR } & \multirow[b]{3}{*}{ UAT } & \multirow{3}{*}{ EQUIP } & & \multirow{3}{*}{$\begin{array}{l}\text { REUSABLE } \\
\text { SUBTOTAL }\end{array}$} & & \\
\hline & & & \multirow{3}{*}{\begin{tabular}{|l} 
LABC \\
MHB \\
\end{tabular}} & \multirow{3}{*}{$\begin{array}{l}\text { ABDF } \\
\text { RATE } \\
\end{array}$} & \multirow{3}{*}{ MAT } & \multirow{3}{*}{ EQuip } & \multirow{3}{*}{1} & & & & & & & \\
\hline & & & & & & & & & & & \multirow{2}{*}{\begin{tabular}{l|l} 
sic & F \\
\end{tabular}} & & \multirow{2}{*}{$\begin{array}{c}\text { SITE- } \\
\text { SPECFIC } \\
\text { SUBTOTAL } \\
\end{array}$} & \multirow{2}{*}{ TOTAL } \\
\hline & & & & & & & & & & & & & & \\
\hline & MOEFIIIZATION & EA & 100.00 & 575 & 50 & & 81,500 & 57,500 & 80 & so & $\$ 1500$ & & $\$ 9,000$ & 59,000 \\
\hline 2.01 & $\begin{array}{l}\text { POWER SOURCE } \\
\text { JRANSFORMER + CONTHOLPANEL }\end{array}$ & EA & 160.00 & 575 & & $\$ 184,000$ & & $\$ 12,000$ & & $\$ 184,000$ & so & $\mathbf{S 1 8 4 , 0 0 0}$ & $\$ 12,000$ & $\$ 196,0000$ \\
\hline & $\begin{array}{l}\text { WAAER SOURCE } \\
\text { MUNGIPAL WATR HOOKUP } \\
\text { WATEP STORAGE TANK (3 TANKS } 12,000 \text { G EACH) } \\
\text { SUBTOTAL } 3\end{array}$ & $\begin{array}{l}\text { EA } \\
\text { MO }\end{array}$ & 160.00 & $\$ 75$ & $\begin{aligned} \$ 11.800 \\
\$ 200\end{aligned}$ & $\$ 2.000$ & $\$ 600$ & $\begin{array}{r}\$ 12,000 \\
\text { so }\end{array}$ & $\begin{array}{l}\$ 11,800 \\
\$ 1,200\end{array}$ & $\begin{array}{r}50 \\
S 12.000\end{array}$ & $\begin{aligned} 5600 \\
\text { so }\end{aligned}$ & & $\$ \$ \$ 24,400$ & $\begin{array}{l}\$ 24,400 \\
\$ 1,200 \\
\$ 37,600\end{array}$ \\
\hline $\begin{array}{r}4.01 \\
4.02\end{array}$ & $\begin{array}{l}\text { STEAM SOUACE } \\
\text { STEAM BOILER } \\
\text { STEAM HOSE }\end{array}$ & $\begin{array}{l}\text { MO } \\
\text { LF }\end{array}$ & $\begin{array}{r}13.33 \\
0.01\end{array}$ & $\begin{array}{l}\$ 75 \\
\$ 75\end{array}$ & & $\begin{array}{l}\mathbf{8 9 , 5 0 0} \\
\mathbf{8 2 5}\end{array}$ & $\$ 800$ & $\begin{array}{c}\$ 5,999 \\
\$ 599\end{array}$ & $\begin{array}{l}\$ 0 \\
\$ 80\end{array}$ & $\begin{array}{l}\$ \$ \$ 7,000 \\
\$ 15,000\end{array}$ & $\begin{array}{r}\$ 4,800 \\
\$ 0\end{array}$ & & $\begin{array}{l}\$ 67.799 \\
\$ 15.599\end{array}$ & $\begin{array}{l}\$ \$ 67,799 \\
\$ 15599 \\
\$ \$ 33,390\end{array}$ \\
\hline $\begin{array}{l}5.01 \\
5.02 \\
5.03 \\
5.04 \\
5.05 \\
5.06 \\
5.07\end{array}$ & 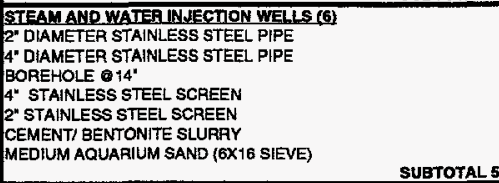 & $\begin{array}{ll}\mathrm{LF} & 360 \\
\mathrm{LF} & 810 \\
\mathrm{LF} & 720 \\
\mathrm{LF} & 210 \\
\mathrm{LF} & 120 \\
\mathrm{CF} & 352 \\
\mathrm{CF} & 306\end{array}$ & $\begin{array}{l}0.03 \\
0.03 \\
0.12\end{array}$ & $\begin{array}{l}\$ 75 \\
\$ 75 \\
\$ 75\end{array}$ & $\begin{array}{l}\$ 20 \\
\$ 49 \\
\$ 90 \\
\$ 55 \\
\$ 2 \\
\$ 1\end{array}$ & & $\$ 14$ & $\begin{array}{r}\$ \$ 91 \\
\$ 1,555 \\
\$ 6,426 \\
\$ 0 \\
\$ 0 \\
\$ 0 \\
\$ 0\end{array}$ & $\begin{array}{r}\$ 7,020 \\
\$ 39,690 \\
\$ 0 \\
\$ 18,900 \\
\$ 6,600 \\
\$ 704 \\
\$ 306\end{array}$ & $\begin{array}{l}\text { so } \\
\text { so } \\
\text { so } \\
\text { so } \\
\text { so } \\
\text { so } \\
\text { so }\end{array}$ & $\begin{array}{r}\$ 0 \\
\$ 0 \\
510,080 \\
\$ 0 \\
\$ 0 \\
\$ 0 \\
\$ 0\end{array}$ & & $\begin{array}{c}\$ 7,711 \\
\$ 4,245 \\
\$ 15,506 \\
\$ 18,900 \\
\$ 6,600 \\
\$ 704 \\
\$ 306\end{array}$ & $\begin{array}{r}\$ 7,711 \\
\$ 41,265 \\
\$ 16506 \\
\$ 18.900 \\
\$ 56,600 \\
\$ \$ 704 \\
\$ \$ 306 \\
\$ 91972\end{array}$ \\
\hline $\begin{array}{l}6.01 \\
6.02 \\
6.03 \\
6.04 \\
6.05 \\
6.06 \\
6.07 \\
6.08 \\
6.09 \\
6.10 \\
6.11 \\
6.12 \\
6.13 \\
6.14 \\
6.15 \\
6.16 \\
6.17 \\
6.12 \\
6.19 \\
6.20 \\
6.21 \\
6.22 \\
6.23\end{array}$ & 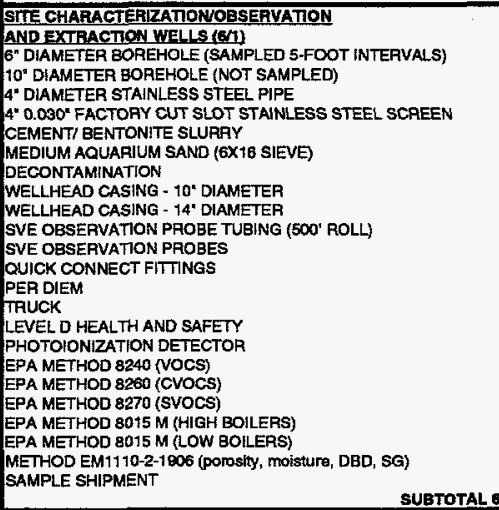 & 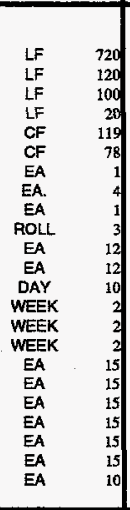 & $\begin{array}{l}0.10 \\
0.08\end{array}$ & $\begin{array}{l}575 \\
\$ 75\end{array}$ & $\begin{array}{r}\$ 49 \\
\$ \$ 0 \\
\$ 2 \\
\$ 1 \\
\$ 150 \\
\$ 180 \\
\$ 300 \\
\$ 12 \\
\$ 18\end{array}$ & $\begin{array}{l}\$ 138 \\
\$ 1364 \\
\$ 331\end{array}$ & $\begin{array}{c}\$ 260 \\
\$ 250 \\
\$ 522 \\
\$ 98 \\
\$ 98 \\
\$ 95 \\
\$ 95\end{array}$ & 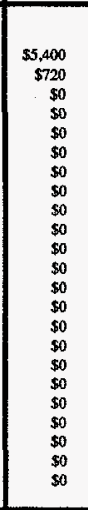 & $\begin{array}{r}\$ 0 \\
\$ 0 \\
\$ 4,900 \\
\$ 1,800 \\
\$ 239 \\
\$ 78 \\
\$ 0 \\
\$ 600 \\
\$ 180 \\
\$ 900 \\
\$ 114 \\
\$ 216 \\
\$ 0 \\
\$ 0 \\
\$ 0 \\
\$ 0 \\
\$ 0 \\
\$ 0 \\
\$ 0 \\
\$ 0 \\
\$ 0 \\
\$ 0 \\
\$ 1,000\end{array}$ & $\begin{array}{l}\$ 0 \\
\$ 0 \\
\$ 0 \\
\$ 0 \\
\$ 0 \\
\$ 0 \\
\$ 0 \\
\$ 0 \\
\$ 0 \\
\$ 0 \\
s 0 \\
\$ 0 \\
s 0 \\
\$ 276 \\
\$ 328 \\
\$ 662 \\
\$ 0 \\
s 0 \\
\$ 0 \\
s 0 \\
\$ 0 \\
\$ 0 \\
\$ 0\end{array}$ & $\begin{array}{r}\$ 12,960 \\
\$ 1,440 \\
\$ 0 \\
\$ 0 \\
\$ 0 \\
\$ 0 \\
\$ 430 \\
\$ 0 \\
\$ 0 \\
\$ 0 \\
\$ 0 \\
\$ 0 \\
\$ 0 \\
\$ 1,000 \\
\$ 0 \\
\$ 0 \\
\$ 00 \\
\$ 3.00 \\
\$ 3,750 \\
\$ 7,80 \\
\$ 1,470 \\
\$ 1.40 \\
\$ 1.425 \\
\$ 0\end{array}$ & & $\begin{array}{l}\$ 18.360 \\
\$ 2,160 \\
\$ 4,900 \\
\$ 1,800 \\
\$ 239 \\
\$ 78 \\
\$ 430 \\
\$ 600 \\
\$ 180 \\
\$ 900 \\
\$ 144 \\
\$ 216 \\
\$ 1,000 \\
\$ 276 \\
\$ 328 \\
\$ 5602 \\
\$ 3,900 \\
\$ 3,750 \\
\$ 7,830 \\
\$ 1,470 \\
\$ 1,470 \\
\$ 1,1425 \\
\$ 1,000\end{array}$ & 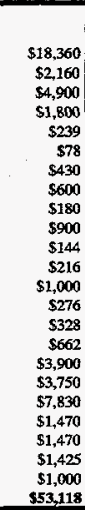 \\
\hline \begin{tabular}{l|}
7.01 \\
7.02 \\
7.03 \\
7.04 \\
7.05 \\
7.06 \\
7.07 \\
7.08 \\
7.09 \\
7.10 \\
7.11 \\
7.12 \\
7.13
\end{tabular} & 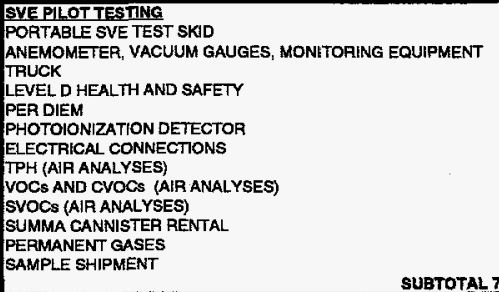 & $\begin{array}{l}\text { DAY } \\
\text { DAY } \\
\text { DAY } \\
\text { DAY } \\
\text { DAY } \\
\text { DAY } \\
\text { EA } \\
\text { EA } \\
\text { EA } \\
\text { EA } \\
\text { EA } \\
\text { EA } \\
E A\end{array}$ & 16.00 & $\$ 75$ & $\$ 100$ & $\begin{array}{l}\$ 100 \\
\$ 100 \\
\$ 32 \\
\$ 36 \\
\$ 36\end{array}$ & $\begin{array}{c}\$ 100 \\
\$ 5500 \\
\$ 120 \\
\$ 400 \\
\$ 460 \\
560 \\
\$ 150\end{array}$ & 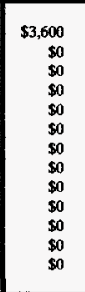 & $\begin{array}{l}\$ 0 \\
\$ 0 \\
\$ 0 \\
\$ 0 \\
\$ 0 \\
\$ 0 \\
\$ 0 \\
\$ 0 \\
\$ 0 \\
\$ 0 \\
\$ 0 \\
\$ 0 \\
\$ 100\end{array}$ & $\begin{array}{c}\$ 300 \\
\$ 300 \\
\$ 96 \\
\$ 216 \\
\$ 00 \\
5108 \\
\$ 0 \\
\$ 0 \\
\$ 0 \\
\$ 00 \\
\$ 0 \\
\$ 0 \\
\$ 0 \\
\$ 0\end{array}$ & 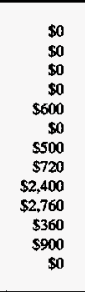 & & $\begin{array}{c}\$ 3.900 \\
\$ 300 \\
\$ 96 \\
\$ 216 \\
\$ 600 \\
\$ 108 \\
\$ 500 \\
\$ 720 \\
\$ 2,400 \\
\$ 2,760 \\
\$ 360 \\
\$ 900 \\
\$ 100\end{array}$ & $\begin{array}{r}\$ 3,900 \\
\$ 300 \\
\$ 96 \\
\$ 216 \\
\$ 6000 \\
\$ 108 \\
\$ 500 \\
\$ \$ 270 \\
\$ 2400 \\
\$ 27600 \\
\$ 360 \\
\$ 500 \\
\$ 100 \\
\$ 12960\end{array}$ \\
\hline 8.01 & $\begin{array}{l}\text { PERMITTING } \\
\text { ARR PEAMITING } \\
\text { GROUNDWATER DISCHAFGE PERMITING }\end{array}$ & $\begin{array}{l}\text { EA } \\
\text { EA }\end{array}$ & $\begin{array}{r}66.67 \\
120.00\end{array}$ & $\$ \$ \$ 75$ & $\begin{array}{r}\$ 500 \\
\$ 1,800\end{array}$ & & & $\begin{array}{l}\$ 5,000 \\
\$ 9,000\end{array}$ & $\begin{array}{r}\$ 500 \\
\$ 1,800\end{array}$ & $\begin{array}{l}\text { so } \\
\text { so }\end{array}$ & so & & $\begin{array}{l}\$ 5,500 \\
\$ 10,800\end{array}$ & $\begin{aligned} \$ 55,500 \\
\$ 10000 \\
\$ 16300\end{aligned}$ \\
\hline $\begin{array}{l}9.01 \\
9.02 \\
9.003 \\
9.04\end{array}$ & $\begin{array}{l}\text { VACUUM SYSTEM } \\
\text { SVE SKD (ALL EQUIPMENT AND VAPOR ABATEMENT) } \\
\text { HCL SCRUBBER AND ANSOCIATED EOUIPMENT } \\
\text { ELECRIICAL CONNETIONS } \\
\text { EQUIPMENT SHIPPING }\end{array}$ & $\begin{array}{l}E A \\
E A \\
E A \\
E A \\
E A\end{array}$ & $\begin{array}{l}213.00 \\
134.00\end{array}$ & $\begin{array}{l}\$ 75 \\
\$ 75\end{array}$ & & $\begin{array}{l}\$ 160,000 \\
\$ 100,000\end{array}$ & $\$ 2,000$ & $\begin{array}{r}\$ 15,975 \\
\$ 10,050 \\
\$ 0 \\
\$ 0\end{array}$ & $\begin{array}{r}\$ 0 \\
\$ 0 \\
\$ 0 \\
\$ 2,500\end{array}$ & $\begin{array}{r}\$ 160,000 \\
\$ 100,000 \\
\$ 0 \\
\$ 0\end{array}$ & $\begin{array}{r}\$ 0 \\
\$ 0 \\
\$ 2,000 \\
\$ 0\end{array}$ & $\begin{array}{l}\$ 160,000 \\
\$ 100,000\end{array}$ & $\begin{aligned} \$ 15,955 \\
\$ 10,050 \\
\$ 2,2000 \\
\$ 22,500\end{aligned}$ & $\begin{aligned} \$ 175,975 \\
5110,050 \\
\$ 2,000 \\
55.500 \\
\$ 220.525\end{aligned}$ \\
\hline \begin{tabular}{|c|}
10 \\
10.01 \\
10.02 \\
10.03 \\
10.04 \\
10.05
\end{tabular} & 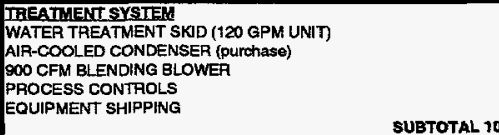 & $\begin{array}{l}E A \\
E A \\
E A \\
E A \\
E A \\
E A\end{array}$ & 80,00 & $\$ 75$ & & $\begin{array}{l}\$ \$ 55,000 \\
\$ 50,000 \\
\$ 4,000 \\
\$ 25,000\end{array}$ & & $\begin{array}{r}\$ 6,000 \\
\$ 00 \\
\$ 00 \\
\$ 0 \\
\$ 0\end{array}$ & $\begin{array}{r}\$ 0 \\
\$ 0 \\
\$ 0 \\
\$ 0 \\
\$ 2,500\end{array}$ & 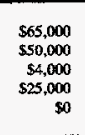 & $\begin{array}{l}\text { so } \\
\text { so } \\
\text { so } \\
\text { so } \\
\text { so }\end{array}$ & $\begin{array}{l}\$ 65,000 \\
\$ 550,000 \\
\$ 45,000 \\
\$ 25,0000\end{array}$ & $\begin{array}{r}\$ 6,000 \\
50 \\
50 \\
50 \\
52,500\end{array}$ & $\begin{array}{r}\$ 71,000 \\
\$ 50,000 \\
\$ 4,000 \\
\$ 25,000 \\
\$ 2,500 \\
\$ 152,500\end{array}$ \\
\hline 1 & SUATOTAL 11 & EA & 200.00 & 575 & $\$ 1.500$ & & $\$ 6,000$ & 515,000 & 51,500 & 80 & $\$ 6,000$ & & 522,500 & $\$ 22500$ \\
\hline 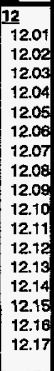 & 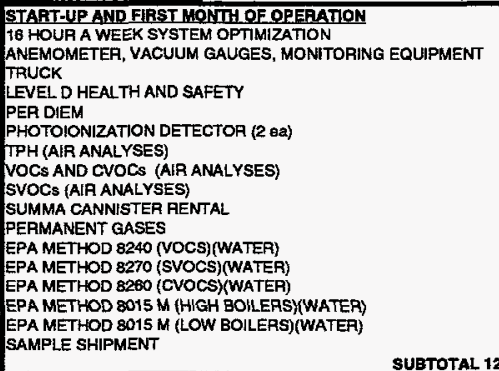 & $\begin{array}{l}E A \\
\text { DAY } \\
\text { DAY } \\
\text { DAY } \\
\text { DAY } \\
\text { DAY } \\
\text { EA } \\
E A \\
E A \\
\text { EA } \\
\text { EA } \\
\text { EA } \\
\text { EA } \\
\text { EA } \\
\text { EA } \\
\text { EA } \\
\text { EA } \\
\text { EA }\end{array}$ & 128.00 & $\$ 75$ & & $\begin{array}{l}\$ \$ \$ 100 \\
\$ 34 \\
\$ 36 \\
\$ 72\end{array}$ & $\begin{array}{l}\$ 100 \\
\$ 120 \\
\$ 400 \\
\$ 460 \\
5160 \\
\$ 150 \\
\$ 250 \\
\$ 5522 \\
\$ 250 \\
\$ 99 \\
\$ 988\end{array}$ & $\begin{array}{c}\$ 9,600 \\
\$ 0 \\
\$ 0 \\
\$ 0 \\
\$ 0 \\
\$ 0 \\
50 \\
\$ 0 \\
\$ 0 \\
\$ 0 \\
\$ 0 \\
\$ 0 \\
\$ 0 \\
\$ 0 \\
\$ 0 \\
\$ 0 \\
\$ 0 \\
\$ 0\end{array}$ & $\begin{array}{r}s 0 \\
\$ 0 \\
s 0 \\
s 0 \\
\$ 800 \\
s 0 \\
s 0 \\
\$ 0 \\
s 0 \\
s 0 \\
s 0 \\
s 0 \\
s 0 \\
\$ 0 \\
s 0 \\
s 0 \\
\$ 200\end{array}$ & $\begin{array}{r}\$ 10 \\
\$ 400 \\
\$ 256 \\
\$ 288 \\
\$ 0 \\
\$ 288 \\
\$ 0 \\
\$ 0 \\
\$ 0 \\
\$ 0 \\
\$ 0 \\
\$ 0 \\
\$ 0 \\
\$ 0 \\
\$ 0 \\
\$ 0 \\
\$ 0\end{array}$ & $\begin{array}{r}\$ 0 \\
\$ 0 \\
\$ 0 \\
\$ 0 \\
\$ 0 \\
\$ 0 \\
\$ 20 \\
\$ 2,400 \\
\$ 2,760 \\
\$ 360 \\
\$ \$ 00 \\
\$ 520 \\
\$ 1,044 \\
\$ 500 \\
\$ \$ 196 \\
\$ 196 \\
\$ 0\end{array}$ & & $\begin{array}{r}\$ 9,600 \\
\$ 400 \\
\$ 256 \\
\$ 288 \\
\$ 800 \\
\$ 288 \\
\$ 720 \\
\$ 2,400 \\
\$ 2,760 \\
\$ 360 \\
\$ \$ 00 \\
\$ \$ 200 \\
\$ 1,044 \\
\$ \$ 500 \\
\$ 196 \\
\$ 196 \\
\$ 200\end{array}$ & 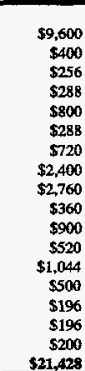 \\
\hline$A_{-1}$ & $1 L$ DIAECT CAPTIAL COST $(1-1)$ & & & & & & & & & & & & 99,300 & 5987,300 \\
\hline & $\begin{array}{l}\text { CONSTRUCTION MANAGEMENT } \\
\text { ENGINEERING, DESIGN, INSPECT } \\
\text { PROJECT MANGGEMENT }\end{array}$ & $\begin{array}{l}10 \% \\
25 \% \\
6 \% 5 \\
6 \%\end{array}$ & & & & & & & & & & $\begin{aligned} \$ 58,8000 \\
\$ 147,000 \\
\$ 335,280\end{aligned}$ & $\begin{array}{l}\$ 399,930 \\
\$ 99,825 \\
\$ 23,958 \\
\end{array}$ & $\begin{array}{r}\$ 99,730 \\
\$ 246,825 \\
\$ 59,238 \\
\end{array}$ \\
\hline & SUBTOTAL & & & & & & & & & & & & & \\
\hline & $\frac{\text { CONTINC }}{\text { TTTALC }}$ & $25 \%$ & & & & & & & & & & & & 1,023 \\
\hline
\end{tabular}




\begin{tabular}{|c|c|c|c|c|c|c|c|c|c|c|c|c|c|}
\hline & $\begin{array}{l}\text { DYNAMIC UNDERGAOUND STAIPPING } \\
\text { OPERATNG \& WONITOFING COST }\end{array}$ & & & & & TFACT & & & & & & $\cos$ & \\
\hline & & & & LABOA & LABOA & & & & & & & & \\
\hline TTEM & DESCAPTION & UNI & QT्र & MHRS & RATE & MAT & EOUIP & sic & LABOR & MAT & EQUIP & sic & TOTAL \\
\hline A & DIAECT COST & & & & & & & & & & & & \\
\hline 1 & WEEKLY FIILL MONTRAIKG & & & & & & & & & & & & \\
\hline 1.01 & 4 HOURS FIELD MONITORING & & 2 & 4.00 & $\$ 75$ & & & & $\$ 600$ & so & so & so & $\$ 600$ \\
\hline 1.02 & ANEMOMETER, VACUUM GAUGES, MONITORING EQUIPMENT & DAY & & & & & $\$ 100$ & & \$o & so & $\$ 100$ & so & $\$ 100$ \\
\hline 1.03 & 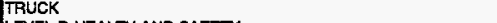 & DAY & & & & & $\$ 64$ & & so & so & $\$ 128$ & $\$ 0$ & $\$ 128$ \\
\hline 1.04 & LEVEL D HEALTH AND SAFETY & DAY & & & & & $\$ 36$ & & \$o & so & $\$ 72$ & $\$ 0$ & $\$ 72$ \\
\hline 1.05 & PER DIEM & DAY & & & & $\$ 100$ & & & \$o & $\$ 400$ & so & so & $\$ 400$ \\
\hline 1.06 & PHOTOIONIZATION DETECTOR (2 ea) & DAY & & & & & \$72 & & so & so & $\$ 144$ & \$o & $\$ 144$ \\
\hline & SUBTOTAL (Weokly Fleld Monhoring) & & & & & & & & $\$ 600$ & $\$ 400$ & $\$ 444$ & $\$ 0$ & 51,444 \\
\hline 2 & QUARIERLY MONITORING AND REPORTING & & & & & & & & & & & & \\
\hline 2.01 & QUARTERLY REPOATTNG & HR & 1 & 121.50 & $\$ 75$ & & & & $\$ 9,113$ & so & so & so & $\$ 9,113$ \\
\hline 2.02 & COMPUTER USEAGE & HA & 63 & & & & $\$ 8$ & & $\$ 0$ & so & $\$ 500$ & \$o & $\$ 500$ \\
\hline 2.03 & VOCS AND CVOCS (AIR ANALYSES) & EA & 2 & & & & & $\$ 400$ & $\$ 0$ & \$o & $\$ 0$ & $\$ 800$ & $\$ 800$ \\
\hline 2.04 & SVOCS (AIP ANALYSES) & EA & 2 & & & & & $\$ 460$ & \$o & so & $\$ 0$ & $\$ 920$ & $\$ 920$ \\
\hline 2.05 & SUMMA CANNISTER RENTAL & EA & 2 & & & & & $\$ 108$ & so & so & so & $\$ 216$ & $\$ 216$ \\
\hline 2.06 & PERMANENT GASES & EA & & & & & & $\$ 150$ & $\$ 0$ & so & so & $\$ 300$ & $\$ 300$ \\
\hline 2.07 & (EPA METHOD 8240 (NOCS)(WATEA) & EA & & & & & & & so & so & so & $\$ 520$ & $\$ \$ 20$ \\
\hline 2.08 & EPA METHOD 8260 (CVOCS)NWTER) & EA & 2 & & & & & $\$ 250$ & so & so & $\$ 0$ & $\$ 500$ & $\$ 500$ \\
\hline 2.09 & EPA METHOD 8270 (SVOCS)(WATEF) & EA & 2 & & & & & $\$ 522$ & $\$ 0$ & $\$$ & $\$ 0$ & $\mathrm{S1,044}$ & $\$ 1,044$ \\
\hline 2.10 & EPA METHOD 8015 M (HIGH BOILERS)(WATER) & EA & & & & & & $\$ 98$ & so & so & $\$ 0$ & $\$ 196$ & $\$ 196$ \\
\hline 2.11 & EPA METHOD 8015 M (LOW BOILERS)(WATER) & EA & 2 & & & & & $\$ 98$ & so & so & \$o & $\$ 196$ & $\$ 196$ \\
\hline 2.12 & ISAMPLE SHIPMENT & EA & & & & $\$ 100$ & & & so & $\$ 200$ & so & $\$ 0$ & $\$ 200$ \\
\hline & SUBTOTAL (Quarterly Wonitoring and Reporting) & & & & & & & & $\$ 9,113$ & $\$ 200$ & $\$ 500$ & $\$ 4,692$ & $\$ 14505$ \\
\hline 3 & YEARLY SYSTEM OPERATION & & & & & & & & & & & & \\
\hline 3.01 & ELECTRICITY (FOR $100 \mathrm{KW}$ O $\$ 5.08$ ' KW. HR) & Mo & 12 & & & $\$ 5,837$ & & & 50 & $\$ 70,044$ & so & so & $\$ 70,044$ \\
\hline 3.02 & WATEA USAGE & Mo & 12 & & & $\$ 2,845$ & & & so & $\$ 34,140$ & $\$ 0$ & so & $\$ 34,140$ \\
\hline 3.03 & SUPPLEMENTAL FUEL (NATURAL GAS) & Mo & & & & & $\$ 26,000$ & & so & \$o & $\$ 312,000$ & so & $\$ 312,000$ \\
\hline & SUBTOTAL Neady Syztem Operation & & & & & & & & so & $\$ 104,184$ & $\$ 312,000$ & so & $\$ 416,184$ \\
\hline & TOTAL (Monthly Operalling a & & & & & & & & & & & & $\$ 45,796$ \\
\hline
\end{tabular}

\begin{tabular}{|c|c|}
\hline $\begin{array}{l}\text { Capital Equipment } \\
\text { Yearly Interest Rate } \\
\text { Amortzation Period (Years) }\end{array}$ & $\begin{array}{r}\$ 1,036,350 \\
3 \% \\
\end{array}$ \\
\hline Yearly Payment & $\$ 224,357$ \\
\hline Total Amortized Equipment Cost & $\$ 1,121,785$ \\
\hline Total Amortlzod Egulpment cost (per month) & $\$ 18,696$ \\
\hline \multicolumn{2}{|l|}{ Dypamke Underground Stripping Costs } \\
\hline $\begin{array}{l}\text { Sito-Specfic Captzal Equipment Cost } \\
\text { Reuspale Capitad Equipment Amortization Cost (6 months) } \\
\text { Operation and Maintenance Cost ( } 6 \text { months) }\end{array}$ & $\begin{array}{l}\$ 703,267 \\
\$ 112,178 \\
\$ 274,774\end{array}$ \\
\hline \multicolumn{2}{|c|}{ 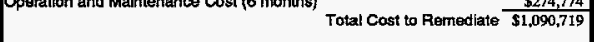 } \\
\hline 9,000 cubic yards) & $\mathbf{5 3 \mathbf { s }}$ \\
\hline
\end{tabular}


Scenario 4 Detalled Costs - Deep Vadiose Zone with Groundwater Contamination

Soil Vapor Extraction --Pump \& Treat-- Costs

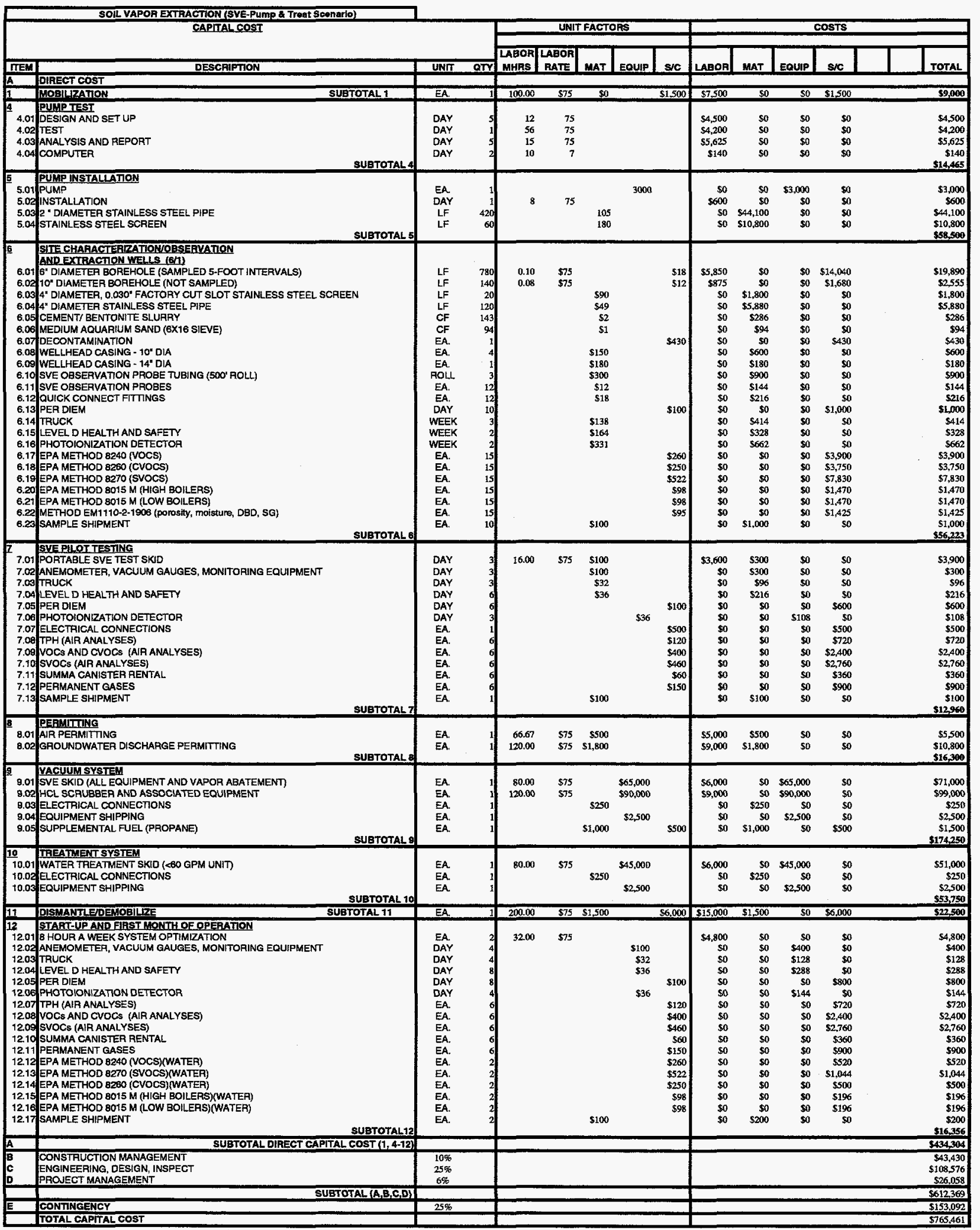


Scenario 5 Detailed Costs - Restricted Access Contamination (beneath building) Radio Frequency Dipole Heating Costs




Scenario 5 Detailed Costs - Restricted Access Contamination (beneath building)

Radio Frequency Dipole Heating Costs (continued)

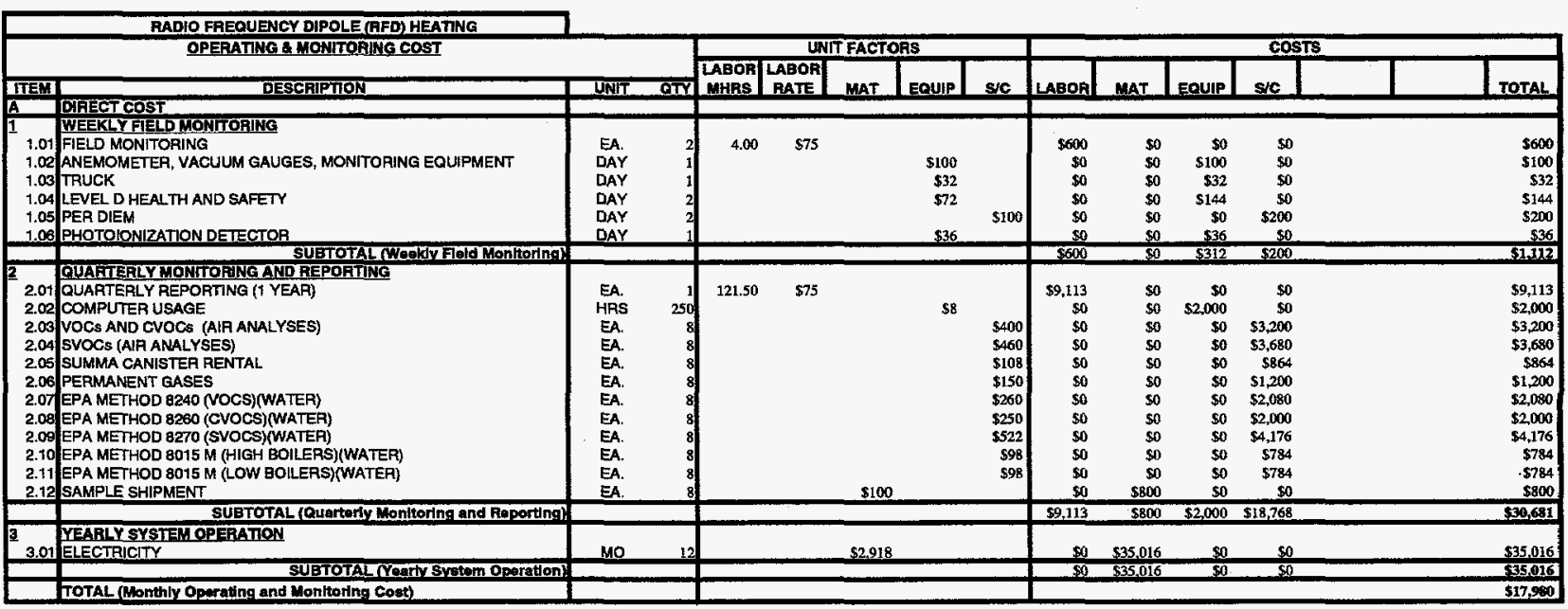

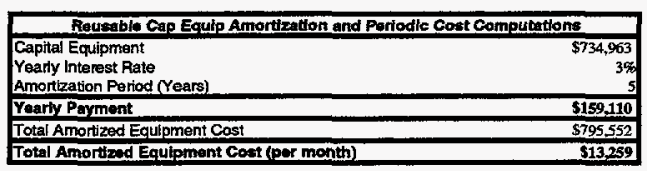

Total Amorifzed Equipment Cost (per month)

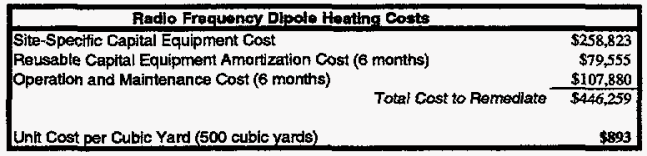




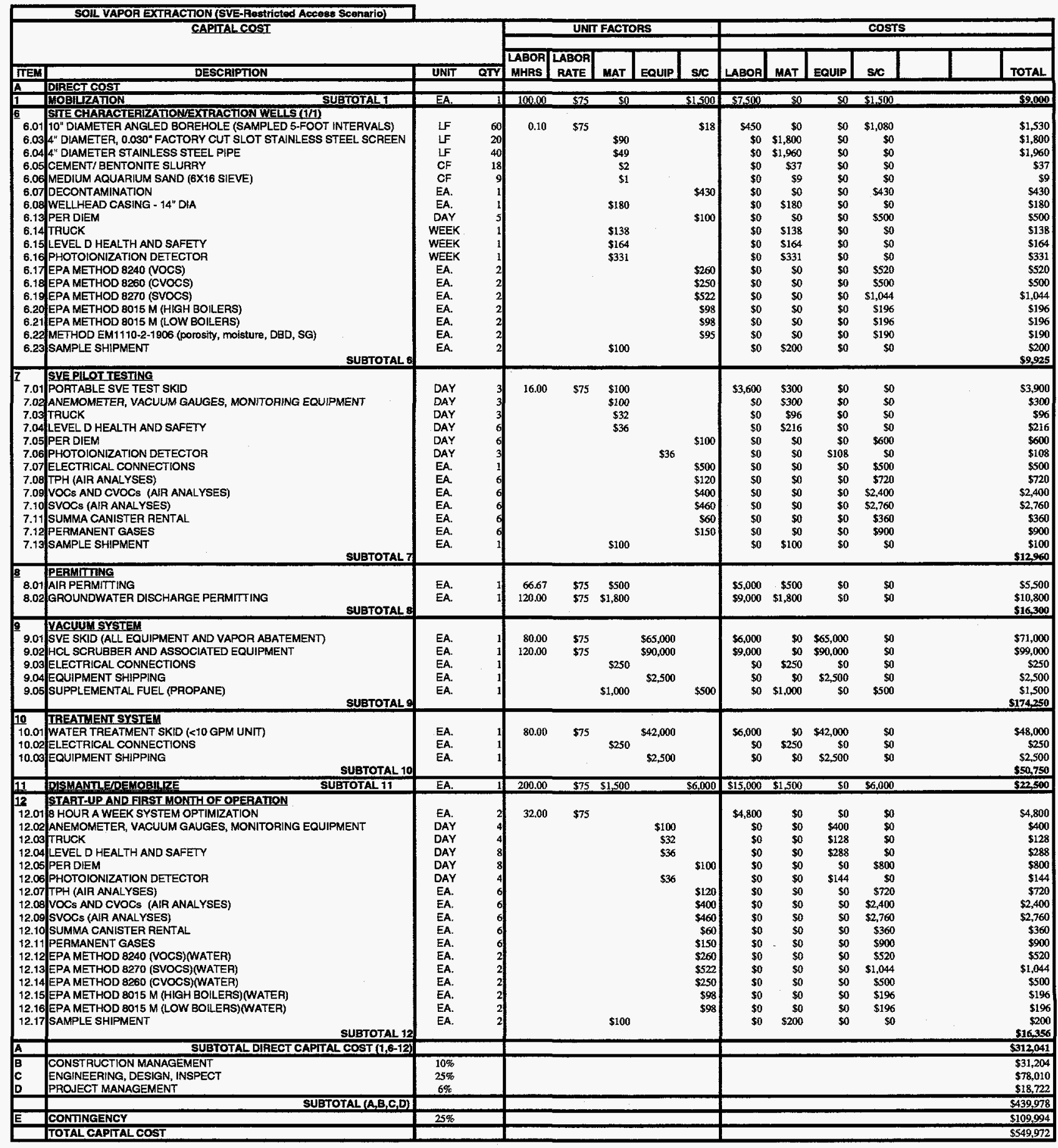


Scenario 5 Detailed Costs -- Restricted Access Contamination (beneath building)

Soil Vapor Extraction -Restricted Access-- Costs (continued)

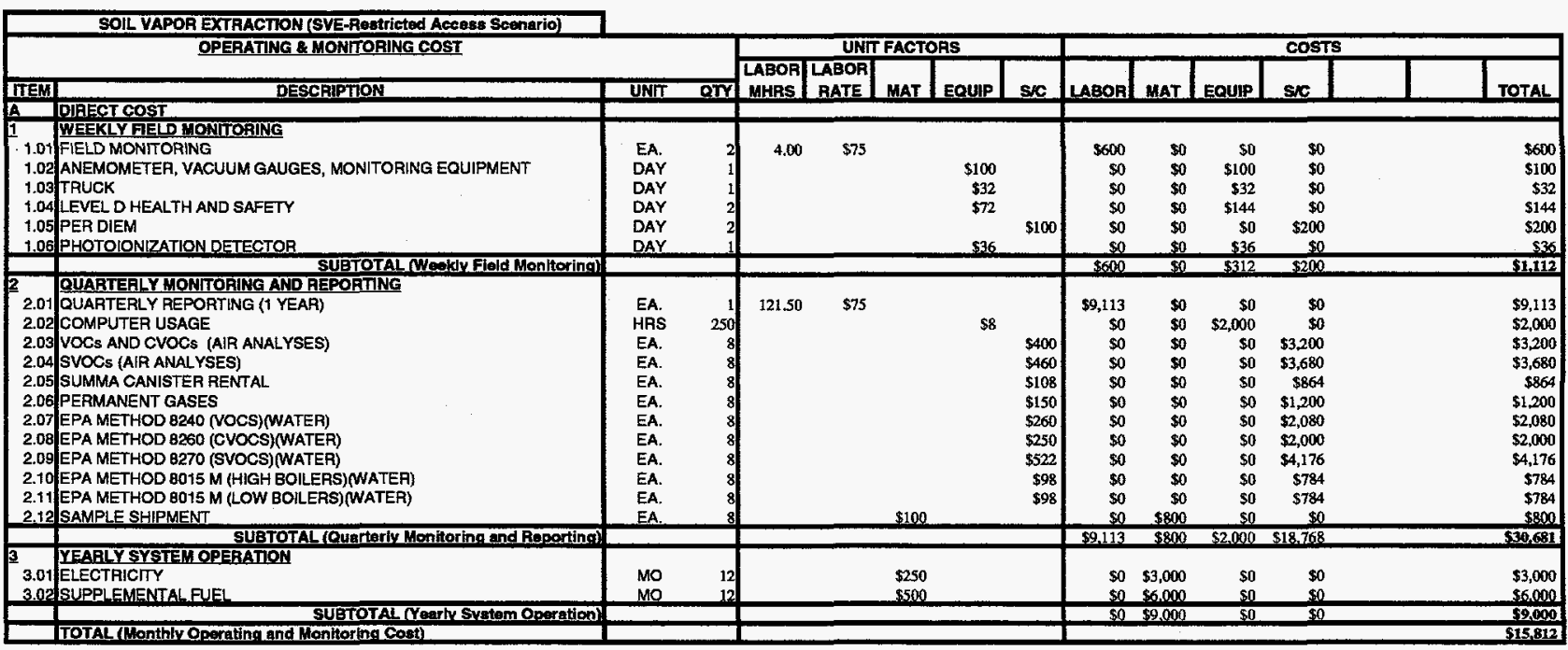

\begin{tabular}{|lr|}
\hline \multicolumn{2}{|c|}{ Capilal Equipment Amortization and Periodic Cost Compatations } \\
\hline Capital Equipment & $\$ 549,972$ \\
Yearly Interest Rate & $3 \%$ \\
Amortization Pariod (Years) & 5 \\
\hline Yoarly Payment & $\$ 119,062$ \\
\hline Total Amortized Equipment Cost & $\$ 595,311$ \\
\hline Total Amortized Equipment Cost (per month) & $\$ 9,922$ \\
\hline
\end{tabular}

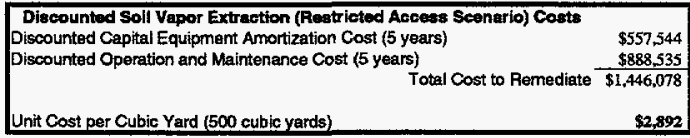

